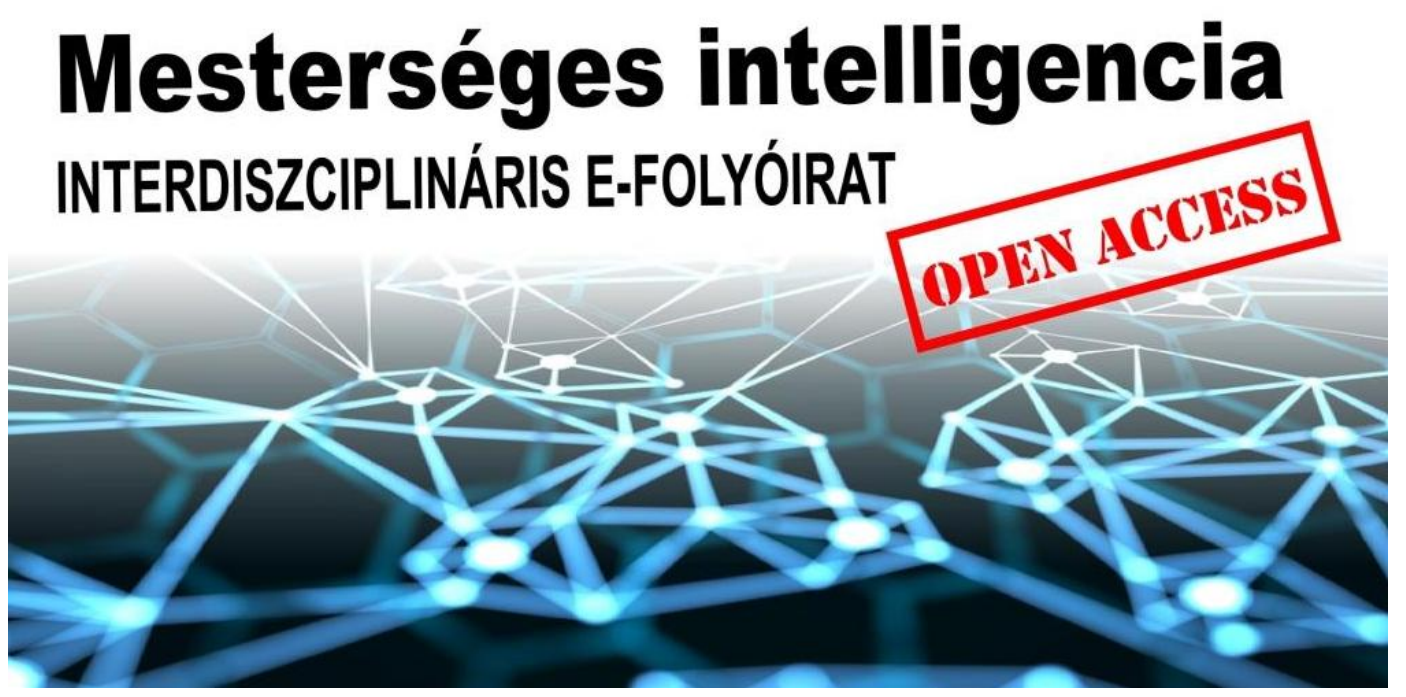

DOI 10.35406/MI.2019.1.1.

ISSN 2676-9611

I. évfolyam 2019/1. szám

WEB: www.kpluszf.com

\title{
K+F STÚDIó Kft.
}




\title{
IMPRESSZUM
}

\section{MESTRESÉGES INTELLIGENCIA}

\author{
Interdiszciplináris e-folyóirat
}

\author{
Alapítva: 2019-ben. \\ ISSN 2676-9611
}

\begin{abstract}
A Nemzeti Média- és Hírközlési Hatóság Hivatala a médiaszolgáltatásokról és a tömegkommunikációról szóló 2010. évi CLXXXV. törvény 46.\$(4) bekezdése alapján nyilvántartásba vett sajtótermék (határozatról szóló értesítés iktatószáma: CE/5420-5/2019).

A Mesterséges intelligencia interdiszciplináris e-folyóirat a K+F Stúdió Kft. által, társadalmi felelősségvállalási (CSR) stratégia keretében alapított és kiadott, negyedévente megjelenő Open Access (nyílt hozzáférésü) internetes periodika, melyben két anonim és két nem anonim szakmai lektor bírál minden tanulmányt.
\end{abstract}

\author{
A Kiadó adatai: \\ Kiadó: K+F Stúdió Kft. \\ A kiadó székebelye: 4032 Debrecen, Tarján utca 55. \\ Mobil: +36-30-4849779 \\ E-mail:info@kpluszf.com \\ Web: www.kpluszf.com \\ Kiadásért felelós squemély: Mező Katalin (PhD),
}

\author{
A Szerkesztőség adatai: \\ Levélcím: K+F Stúdió Kft., 4032 Debrecen, Tarján utca 55. \\ Mobil: +36-30-4849779 \\ E-mail:info@kpluszf.com \\ Web: www.kpluszf.com \\ Alapitó föszerkesz̨ő: Mező Ferenc (PhD) \\ Tördeló sz̨erkesz̨tó: Mező Katalin (PhD)
}

\section{Együttmüködő civil szervezet:}

Kocka Kör Tehetséggondozó Kulturális Egyesület (www.kockakor.hu)

Professzorok az Európai Magyarországért Egyesület (www.peme.hu)

\section{Szerkesztőség (ABC rendben):}

Demetrovics János (Prof. Dr., akadémikus, MTA SZTAKI)

Gyarmati Péter (Dr. Prof.)

Kelemen Lajos (PhD, OKOSKOCKA Kft.)

Koncz István ( $\mathrm{PhD}, \mathrm{CSc}$, Professzorok az Európai Magyarországért Egyesület)

Mező Ferenc (PhD, K+F Stúdió Kft.)

Mező Katalin (PhD, Debreceni Egyetem)

Orbán Réka (PhD, Babes-Bolyai Egyetem)

Pénzes Dávid (Drs, Káldor Miklós Kollégium)

Pšenáková Ildikó (PhD, Trnava University in Trnava, Szlovákia)

Roskó Tibor (Drs, Debreceni Egyetem)

Simó Ferenc Zoltán (dr., LL.M, Debreceni Egyetem)

Szabóné Balogh Ágota (PhD, Gál Ferenc Főiskola)

Szúts Zoltán (PhD, Budapesti Múszaki és Gazdaságtudományi Egyetem)

Vass Vilmos (PhD, habil., Budapesti Metropolitan Egyetem, Selye János Egyetem)

Vámos Tibor (Prof. Dr., akadémikus, MTA SZTAKI)

Külön nem hivatkozott illusztrációk forrása: https://pixabay.com 


\section{TARTALOM}

SZERKESZTŐI KÖSZÖNTŐ

ELMÉLETI ÉS EMPIRIKUS TANULMÁNYOK

Mező Ferenc és Mező Katalin:

INTERDISZCIPLINÁRIS KAPCSOLÓDÁSI LEHETŐSÉGEK A MESTERSÉGES

INTELLIGENCIÁRA IRÁNYULÓ CÉL-, ESZKÖZ- ÉS HATÁSORIENTÁLT

KUTATÁSOKHOZ

Gyarmati Péter:

GONDOLATOK A MESTERSÉGES INTELLIGENCIA, A GÉPI TANULÁS KAPCSÁN

Molnár Balázs:

PARADIGMAVÁLTÁSOK AZ ELEKTRONIKUS TANULÁSI KÖRNYEZETEK

FEJLŐDÉSÉBEN I.

Csibi Mónika és Csibi Sándor:

SZÁMÍTÓGÉPES DOHÁNYZÁS-PREVENCIÓ AZ ISKOLÁBAN

MÓDSZERTANI TANULMÁNYOK

Mező Ferenc, Mező Katalin és Mező Kristóf Szíriusz:

FILMKLUBOK SZEREPE A MESTERSÉGES INTELLIGENCIÁVAL

KAPCSOLATOS ATTITUUDÖK FORMÁLÁSÁBAN

MÜHELY, RENDEZVÉNY .95

Mező Katalin:

A K+F STÚDIÓ ÉS A MESTERSÉGES INTELLIGENCIA (MÜHELYBEMUTATÓ) .97 


\section{SZERKESZTŐI KÖSZÖNTŐ}

\section{Tisz̧telt Olvasó!}

Engedje meg, hogy örömmel üdvözöljem a Mesterséges intelliegencia folyóirat I. évfolyam 1. számának megjelenése alkalmából!

E folyóirat célja, hogy lehetôséget biztosítson a mesterséges intelligencia (MI, angol terminológia: artificial intelligence, $\mathrm{AI}$ ) témakör iránt tudományos érdeklődéssel (is) fordulók számára kutatási eredményeik, jó gyakorlataik, alkotó múhelyeik, gondolataik megosztására. Sôt: cseréjére, az aktív párbeszédre és közös projektek megvalósítására.

Kiknek szól a lap? Íme:

Kutatóknak: a Magyar Tudományos Akadémia által kiadott, jelenleg is érvényben lévő tudomnyági nómenklatúrában megjelölt minden diszciplina képviselője érdekelt lehet a mesterséges intelligencia kutatásában és/vagy felhasználásában, vagy a mesterséges intelligencia és a világ kölcsöncsönhatásának kutatásában. Hisszük, hogy a folyóirat idővel lényeges szerepet tölthet be a tudományközi párbeszéd elősegítésében.

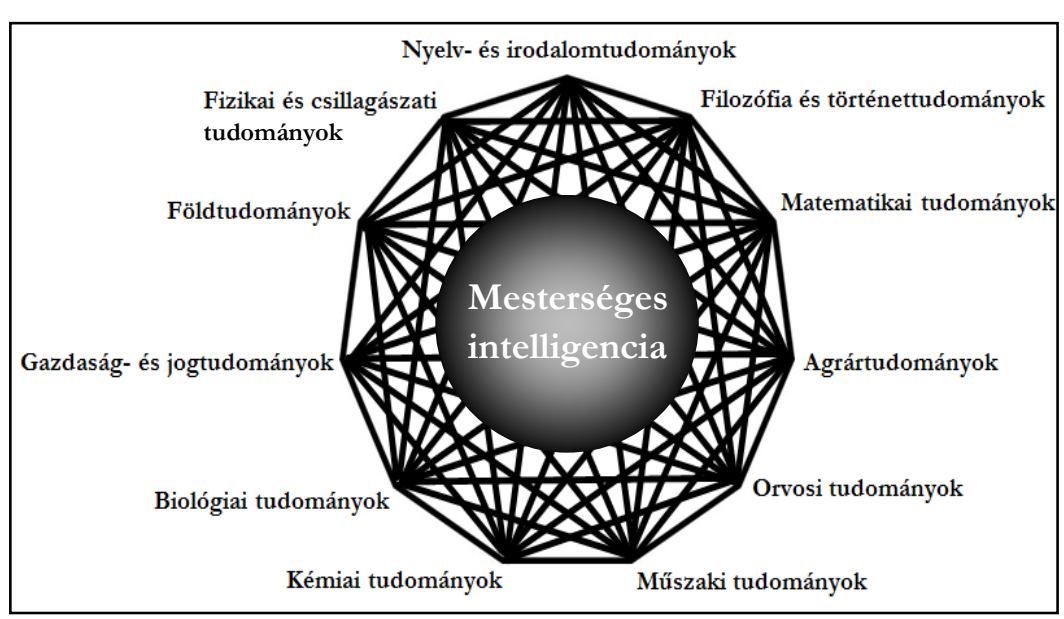

Pedagógusoknak, egyetemi oktatóknak: vagyis azoknak, akik kulcsszerepet játszanak a jelenlegi és a következő generációk felkészítésében, nevelésében, MI témakörrel kapcsolatos attitűdjeik formálásában. Tekintettel arra, hogy az MI témakör nem képezi a reguláris pedagógusképzés részét (egyetemi oktatói felkészítés, mint olyan pedig nem létezik), különösen fontos szerepe lehet a lapnak a pedagógusok, oktatók munkájának segítésében.

Szervežteknek (állami, civil, gaz-dasági, egyházi szervezeteknek): profit orientált és non-profit szervezetek egyaránt érdekeltek lehetnek egyrészt az MI kutatása, fejlesztése innovációja kapcsán, másrészt az MI hasznosítása, szervezetbeli bevezetésére (vagy akár: elkerülésére) irányuló törekvéseik miatt.

Tematikáját tekintve pedig a szoros értelemben vett MI-re fókuszáló írásokon túl, a témához szorosan kötődő digitális kompetenciával, info-kommunikációval foglalkozó tanulmányoknak is helye van a lapban.

\section{Legyen Ön is Olvasónk, Szerzőnk vagy tematikus számot összeállító \\ Szerkesztőnk!}

Üvözlettel a Szerkesztöség nevében is:

Dr. Mező Ferenc alapító fôszerkesztő 
ELMÉLETI ÉS EMPIRIKUS TANULMÁNYOK 


\title{
INTERDISZCIPLINÁRIS KAPCSOLÓDÁSI LEHETŐSÉGEK A MESTERSÉGES INTELLIGENCIÁRA IRÁNYULÓ CÉL-, ESZKÖZ- ÉS HATÁSORIENTÁLT KUTATÁSOKHOZ
}

\section{Szerző:}

Mező Ferenc (PhD)

Eszterházy Károly Egyetem

Mező Katalin (PhD)

Debreceni Egyetem

Első szerző e-mail címe:

ferenc.mezo1@gmail.com

\section{Lektorok:}

Demetrovics János (Prof., Dr., akadémikus) MTA SZTAKI

Koncz István (PhD, CSc)

Professzorok az

Európai Magyarországért Egyesület

...és további két anonim lektor

\begin{abstract}
Absztrakt
A különböző diszciplinák kutatói legalább három módon kapcsolódhatnak a mesterséges intelligencia (MI) témájához. Ezek a lehetőségek: cél-, eszköz- és hatásorientált megközelítések. Jelen tanulmány bemutatja ezeket a megközelítéseket, és számos interdiszciplináris példát ad a mesterséges intelligencia témáinak kutatására.
\end{abstract}

Kulcsszavak: mesterséges intelligencia, MI, interdiszciplináris kutatás

Diszciplina: interdiszciplináris

\begin{abstract}
INTERDISCIPLINARY CONNECTIVTTY OPTIONS FOR GOAL-, ASSET- AND EFFECT-ORIENTED RESEARCHES OF ARTIFICLAL INTELLIGENCE

Researchers of different disciplines can connect to theme of artificial intelligence (AI) by least three ways. These possibities are: goal-, asset- and effect-oriented approaches. Present study shows on these approaches and it gives a number of interdisciplinary examples about researching topics of artificial intelligence.
\end{abstract}

Keywords: artificial intelligence, AI, interdisciplinary research

Discipline: interdisciplinary

Mező Ferenc (2019): Interdiszciplináris kapcsolódási lehetőségek a mesterséges intelligenciára irányuló cél-, eszköz- és hatásorientált kutatáshoz. Mesterséges intelligencia - interdiszciplináris folyóirat, I. évf. 2019/1. szám. 9-29. doi: 10.35406/MI.2019.1.9 
A „mesterséges intelligencia” (MI, angol megnevezés: artificial intelligence, AI) kifejezést - az Európai Bizottság fogalomtára (AI HLEG, 2018) szerint - olyan rendszerekre alkalmazhatjuk, amelyek a környezetük elemzése és bizonyos fokú önállósággal járó cselekvéseik révén intelligens viselkedést mutatnak specifikus célok elérése érdekében. Az MI-alapú rendszerek lehetnek: a) tisztán szoftver alapúak (kizárólag a virtuális világban tevékenykedő jellegűek - például: hangasszisztensek, képelemző programok, keresőmotorok, beszéd- és arcfelismerő rendszerek stb.), b) hardverbe ágyazott szoftverek (robotok, önvezető járművek, drónok vagy internetes applikációk).

A mesterséges intelligencia kutatásához legalább háromféle megközelítésből kapcsolódhatnak a különböző diszciplinák kutatói (1. táblázat). Ezek:

1. Cél jellegű megközelítés;

2. Eszköz jellegű megközelítés;

3. Hatás-orientált megközelítés.

\section{A mesterséges intelligencia mint kutatási cél}

A mesterséges intelligencia kutatása során cél jellegü megkë̈zelités $(\mathrm{MI}=$ cél) történik akkor, ha az alap- vagy alkalmazott kutatás tárgya maga a mesterséges intelligencia létrehozását, megismerését segítő elméleti és gyakorlati ismeretek és összefüggések feltárása. E kutatások arra keresik a választ, hogy „Mi a mesterséges intelligencia, és hogyan hozható létre?".
A mesterséges intelligencia cél jellegú kutatásához legközvetlenebb módon kapcsolódó tudományterületek: matematika, informatika, kibernetika, pszichológia, filozófia, nyelvészet.

E tudományágak már a mesterséges intelligencia kutatásának leggyakrabban említett úttörőinél is megtalálhatók, s egyben jelzik a téma interdiszciplináris jellegét:

John McCarthy (1927-2011) matematikus, 1955-ben az ,artificial intelligence” kifejezés megalkotója, az MI történetében úttörő jelentőségű 1956-os Darthmouthkonferencia összehívója.

Alan Mathison Turing (1912-1854), matematikus, kódfejtő, filozófus, biológus, aki formalizálta a komputáció, az algoritmus fogalmát, nevéhez kötődik többek között a Turing-gép (általános célú számítógép) felvetése, a Turing-próba (el tudjuk-e dönteni a beszélgető társunkról, hogy ember-e vagy gép. Ha beszélgetőtárs gép és embernek hisszük, akkor lényegében teljesítette a Truring-próbát).

Marvin Lee Minsky (1927-2016) matematikus, kognitív tudós, a mesterséges neurális hálózatok úttörő kutatója.

Allen Newell (1927-1992) kognitív pszichológus, matematikus, az első igazi MI programok és programnyelvek alkotója.

Herbert Alexander Simon (1916-2001) közgazdász, politikai tudós, kognitív pszichológus, közgazdasági Nobel-díjas. Az MI terén az információfeldolgozás, döntéshozás, problémamegoldás, szervezetelmélet, komplex rendszerek, programnyelvek, ember-gép interakció témakörökben alkotott. Nevéhez kötődik az EPAM Elementary Perceiver and Memorizer program, ami a verbális tanulás jelenségeinek szimulálására szolgált. 
1. táblázat: A mesterséges intelligencia (MI) kutatások lehetséges orientációja (forrás: a Szerzőo)

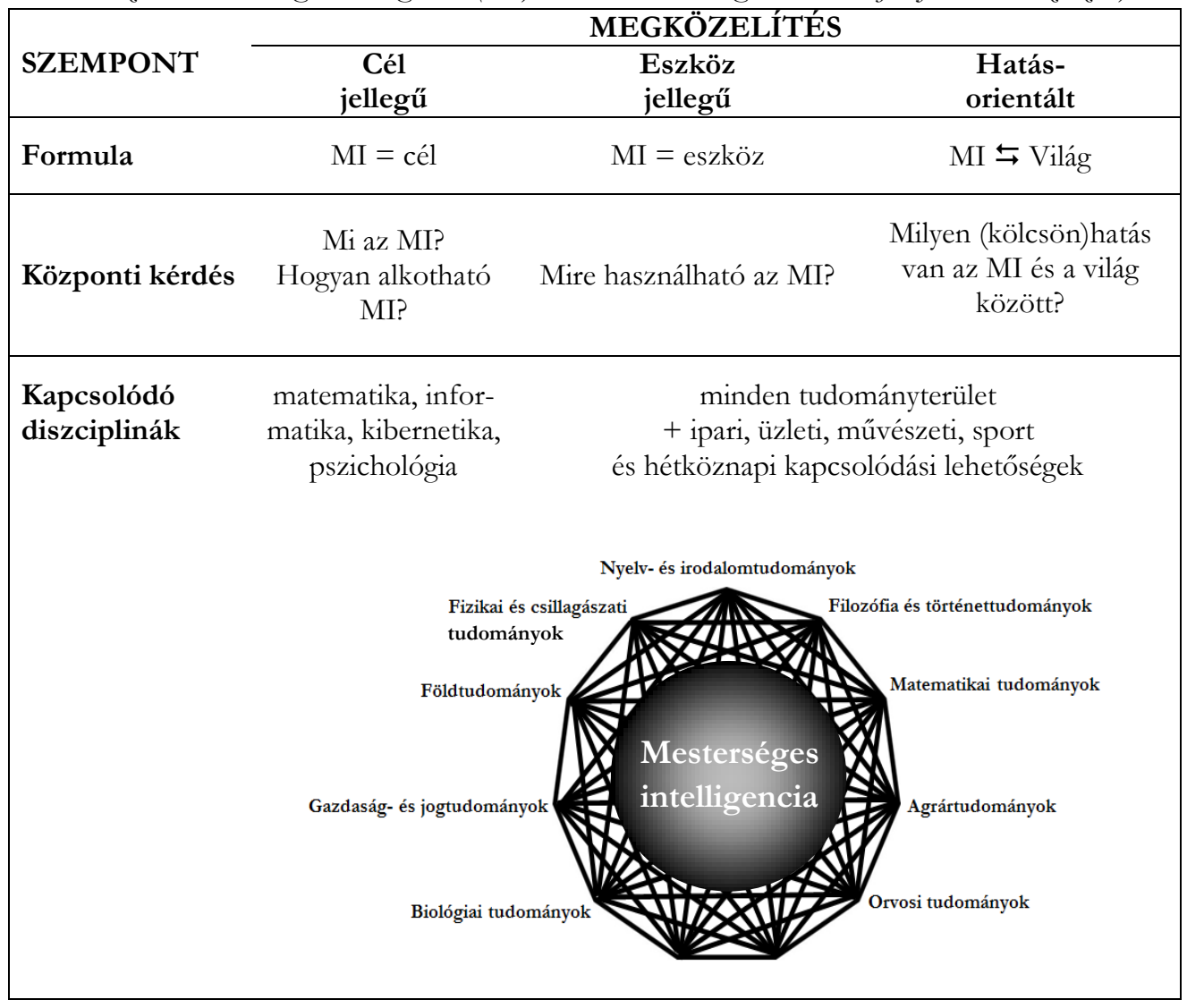

A mesterséges intelligenciára olykor önálló tudományterületként is történik utalás. A Digitális Jólét Program fogalomtára szerint: „A mesterséges intelligencia e pillanatban alapvetően egy tudományág, ami arra törekszik, hogy az emberihez hasonló tudással, memóriával, és szintetizáló képességgel ruházzunk fel gépeket”. Az MI mint tudományterület többféle megközelítést és technikát jelenthet - többek között (AI HLEG, 2018):

- a gépi tanulást (Machine Learning). Ennek speciális esetei például a mély tanulás és a megerősítő tanulás. A mélytanulás (Deep Learning) az MI neurális hálózatok elemzésével foglalkozó tudáselsajátító képessége (a neurális hálózatok - neural networks - az emberi idegrendszeri mûködést próbálják szimulálni - a témával kapcsolatban lásd: Altrichter és tsai, 2006 múvét). A megerôsítő tanulás (vagy Reinforcement Learning) lényege pedig: az MI helyes döntés esetén ,jutalom jelet” kap, ami jelzi számára a döntés helyességét, s igyekszik a jövőben maximalizálni a jó döntések/jutalmak számát). 
- a gépi gondolkodást (lásd: Machine Reasoning), ami egyben tartalmazza a tervezést, ütemezést, tudás reprezentációt és következtetést, keresést és optimalizálást is;

- robotikát (Robotics). A robot leegyszerűsítve: MI által irányított fizikai gép (kivétel: szoftver robot).

A szoftver robotok (Roboting Process
Automation, RPA) olyan számítógépen
futó programok, amelyek rutinszerű fela-
datokat (például: kéretlen levelek törlését)
képesek végrehajtani az irányításuk alá
vont szoftvereken, hardvereken.
A robotok speciális csoportjába sorol-
hatók az androidok (másként: humanoid
robotok), melyek az ember fizikai meg-
jelenését és viselkedését utánozzák.

A robotika magába foglalja az ellenőrző, észlelő, az érzékelő- és a működtető szerkezetek (például szenzorok, fogókarok stb.), valamint az összes többi technika integrálását a számítógépes (kiber-) fizikai rendszerekbe. A robotika már elektronikai, gépészmérnöki, mechatronikai kompetenciákat is igényel.

A mesterséges intelligencia cél jellegű kutatása terén két nagy irányzatot különböztethetünk meg - ezeket a ,gyenge $M I$ " (Weak AI) és az „erós MI” (Strong AI) néven illeti a szakirodalom. A ,gyenge MI" mindössze egy vagy néhány konkrét feladat ellátására képes rendszert jelent (napjainkban ilyen alkalmazásokkal találkozhatunk a hétköznapokban is). Az „erōs MI” célja általánosabb jellegű, a humán pszichét (és robotok vagy audiovizuális megjelenésű MI-k esetében akár a humán külsőt is!) utánzó szoftver/hardver létrehozása (AI HLEG, 2018).

A „mesterséges pszichológiát” elméleti
tudományágként 1963-ban Dan Curtis
említette elôször (hivatkozik rá: Crowder
és Friess, 2012). Megközelítésében a mes-
terséges intelligencia akkor fogja az emberi
intelligencia komplexitási szintjét megkö-
zelíteni (tehát akkor beszélhetünk az „erős
MI” megvalósulásáról, ha az MI meg tud
felelni az alábbi három kritériumnak:
1) Képes önálló, emberi felügyelet és be-
avatkozás nélküli döntéshozatalra új
és/vagy absztrakt és/vagy hiányos infor-
mációk alapján is.
2) Még hiányos információk esetében is
képes átprogramozni magát (fejlődik, ta-
nul), s képes megoldani saját programozási
konfliktusait.
3) Az 1) és a 2) kritérium olyan új hely-
zetekben is jelentkezik, melyek nem voltak
eredetileg eltervezve és az elóállítók által
beprogramozva.

Jelen cikknek nem célja ugyan mélyrehatóan bemutatni a mesterséges intelligencia alapfogalmait, útmutatót azonban ad a téma iránt érdeklődők számára. Magyar nyelven a Digitális Jólét Program (2019) „DJP Digitalizációs fogalomtár” címû összeállítása lehet irányadó. Némileg bővebb, de még mindig „olvasmányos” stílusú az Európai Bizottság mesterséges intelligenciával foglalkozó szakértő csoportja által 2018-ban összeállított fogalomtár (AI HLEG, 2018). Az alapfogalmak megismerését követően a részletekbe menő magyar nyelvű szakirodalmak tekintetében 
Gubán (2014), Cawsey (2002), Futó (1999), illetve a „Mesterséges intelligencia elektronikus almanach"-ban (2011) található mûvek segíthetnek a témával való ismerkedésben.

\section{A mesterséges intelligencia mint eszköz}

Az eszköz jellegü megközelités (MI = eszköz) a mesterséges intelligencia adott tudományos, üzleti, szakmai, művészeti, sport vagy egyéb hétköznapi területeken történő felhasználására fókuszál (elsősorban alkalmazott tudományként, de vegyük észre, hogy nemcsak tudományos felhasználásról lehet szó!).

E megközelítés központi kérdése: „Mire használható a mesterséges intelligencia (általában vagy egy adott területen)?”

A mesterséges intelligencia eszköz jellegû kutatásához jóformán minden tudomány, szakma, múvészet, sport vagy egyéb hétköznapi felhasználás felől kapcsolódhatunk. A mesterséges intelligencia témában nem feltétlenül jártas olvasóközönség leginkább az MI eszköz jellegú megközelítésével találkozhat a médián keresztül. Az alábbi, mesterséges intelligenciával kapcsolatos internetes hírekből öszszeállított válogatás tükrözi, hogy az ingyenesen, tömegesen elérhető populáris médiaként funkcionáló hírportálokon keresztül milyen hatások érhetik az Olvasókat. E cikkek olvasói például tudhatják, hogy a mesterséges intelligencia többek között alkalmas eszköze lehet gazdasági, oktatási, környezetformálási, egészségügyi, művészeti céloknak is.

\section{Az MI, mint a gazdaság eszköze}

A mesterséges intelligencia sokoldalú gazdasági változásokat eredményez, s hatása az ipari forradaloméhoz mérhető (Net1). Jellemző sajtóanyagok ezzel kapcsolatban például: „Az MI hajtja a digitális gazdaságot” (IT café, 2019a) című írás arról számol be, hogy a Huawei GCI index (Global Connectivity index - 79 országot érintő, az országok digitális transzformációjának alakulására fókuszáló felmérés) tapasztalata, hogy még a mesterséges intelligencia terén élen járó országok sem tudják teljesen kihasználni az MI nyújtotta lehetőségeket (leginkább az MI fejlesztők hiánya miatt - vesd. össze: az MI oktatási célú felhasználásával kapcsolatos alábbi bekezdéssel!). Hazai szinten problémát jelent, hogy a digitális versenyképesség terén még mindig sereghajtóknak számítunk (Dajkó, 2019a).

Pedig a témába vágó hírek szerint az Olvasók értesülhetnek arról, hogy az informatikában, a digitális gazdaságban, s ezzel összefüggően a mesterséges intelligencia alapú technológiában „sok pénz van" - lásd: külföldön 34 milliárd dolláros informatikai gigafelvásárlásokról olvashatunk (Net2), Magyarországon 150 milliárd forintos informatikai óriáscég létrehozásáról szólnak a hírek (Net3).

A mesterséges intelligencia áttételesen is hatással lehet a gazdaságra: a monetáris politika iránya, a bankok vezetőinek stra- 
tégiája gépi segítséggel, adatelemzéssel kiszámíthatóbbá válik (Rácz, 2019). Ezzel összefüggésben „A bankok már nem a pénzre vigyáznak leginkább” (Szabó, 2019), hanem az adatokra, s kincset érnek az adatokat nyereségesen kezelő banki algoritmusok. Az is kiderül a hírportálokat böngésző egyszeri Olvasó számára, hogy nemcsak a bankok, hanem cégek, magánszemélyek esetében is felértékelődik az adatok védelme (Bolcsó, 2019): a jelszavak lopása, a netes zsarolások, zsarolóvírusok alkalmazása, az adatlopás is egyre hétköznapibbá válik sajnos, s erkölcsi károkon túl jelentôs anyagi károkat okoz.

Másrészt az adatok megosztása a mesterséges intelligencia gazdasági alkalmazásában és/vagy kutatásában kontrollált körülmények között minden partner számára gyümölcsöző is lehet (Microsoft News Center, 2019). Sőt: már arra is van precedens, hogy iparági összefogás született a túl okos fegyverek ellen (Dajkó, 2018a) tekintve, hogy a mesterséges intelligenciának katonai alkalmazása is lehetséges.

A hazai együttműködésről szól az Innovációs és Technológiai Minisztérium támogatásával megalakult - 181 szervezetet tömörítő - Mesterséges Intelligencia Koalíció is, ami a nemzeti MI stratégiát dolgozza ki, valósítja meg (Szepesi, 2019). Az MI Koalíció célja (v.ö.: https://digitalis joletprogram.hu/hu/tartalom/mestersege s-intelligencia-koalicio), hogy:

- „hazánk az MI fejlesztések terén mihamarabb az európai élvonalba kerüljön, ezáltal Magyarország a nemzetkö- zi MI közösség fontos referenciapontjává váljon;

- az MI alapú fejlesztések széleskörű elterjedésének és alkalmazásának köszönhetően jelentősen erősödjön a hazai vállalkozások versenyképessége;

- a magyar startupok és kkv-k nagy arányban vegyenek részt MI fejlesztésekben, akár nagyvállalati, egyetemi vagy nemzetközi partnerségben;

- az állam a nemzeti adatvagyon átgondolt hasznosításával, valamint a digitális ökoszisztéma minden szereplője az adatvagyonok tisztességes, szabályozott és hatékony hasznosításával, illetve az MI-megoldások felhasználójaként vegye ki a részét a magyar társadalom és a nemzetgazdaság fejlesztésében."

Mindemellett meg kell említeni, hogy napjainkban már az ipari robotok fogalma sem ismeretlen a népesség előtt.

Jelentős gazdasági következményekkel is járó közvéleményt formáló hatása lehet azoknak a médiatartalmaknak is, melyek a munkavállalói, illetve munkáltatói oldalról elemzik a mesterséges intelligencia bevezetését. Az IT café (2018a) összefoglalója szerint például egy 1320 fős felmérés eredménye, hogy az emberek többsége számára nem jelentene problémát, ha munkahelyükön robotoktól kellene utasításokat elfogadniuk. Egy másik összefoglaló pedig egy ( $n=1800$ fő) nemzetközi kutatást vázol, aminek eredményei szerint a fiatalok bátran alkalmazzák az MI-t (IT café, 2018b). 


\section{Az MI alkalmazása}

\section{oktatási feladatok ellátására, támogatására}

Finnország a mesterséges intelligencia oktatásában látja a jövőt (Delcker, 2019, Dajkó, 2019), többek között annak érdekében, hogy polgárai tisztában legyenek az MI lehetőségeivel. Ebből a szempontból nem lehet figyelmen kívül hagyni az okoseszközök gyermekkori használatának jellemzőit sem (IT café, 2018c), miként a pedagógusok digitális módszertani eszköztárát sem (IT café, 2019b - lásd még: Antalné, 2019). A Szakképzés 4.0 (lásd: 1168/2019. kormányhatározat) és a Digitális Oktatási Stratégia (lásd: 1536/2016. kormányhatározat) megtremtették a hátterét annak, hogy digitális közösségi alkotómúhelyekben játékosan ismerkedhessenek meg a résztvevők a mesterséges intelligencia tervezésével és felhasználásával (Birkás, 2019). A Digitális Kompetencia Keretrendszer (DigKomp lásd: 1341/ 2019. kormányhatározat) célja, a digitálisan felkészült munkavállalók körének bővítése, annak érdekében, hogy a digitális felkészületlenség miatt Magyarországon senki se kerüljön hátrányba a digitális gazdaságot egyre inkább előtérbe helyező világban. Mindehhez cégek, szervezetek általi kezdeményezések is rendelkezésre állnak hazánkban (Net4, illetve: a $\mathrm{K}+\mathrm{F}$ Stúdió Kft. MI projektjei).

Másrészt lehetőség van nemzetközi versenyekbe történő bekapcsolódásra is: 2019. novemberében például Győrben kerül megrendezésre a World Robot Olympiad 2019 (WRO2019 Hungary) verseny (IT café, 2019c), melynek központi témája a SMART Cities lesz (versenyszabályokat lásd: https://wroassociation.org/wro-2019/games-rules/).

Az oktatás és a mesterséges intelligencia viszonyára jellemző, hogy az oktatás tartalma vonatkozhat a mesterséges intelligenciára, mint célra, mint eszközre és az MI-világ kölcsönhatásra egyaránt.

Az MI és az oktatás kapcsolatában ragadható meg leginkább az informatika, pedagógusok és diákok informatikai oktatása, digitális kompetencia, digitális gazdaság, mesterséges intelligencia egymást kölcsönösen meghatározó viszonyrendszere (1. ábra). E komponensek kölcsönösen hatnak egymásra: bármelyik összetevőben beálló változás hatással van a hálózat többi elemére is.

1. ábra: az MI és nébány kiemelt társtéma összefüggése (forrás: a Szuerzóke)

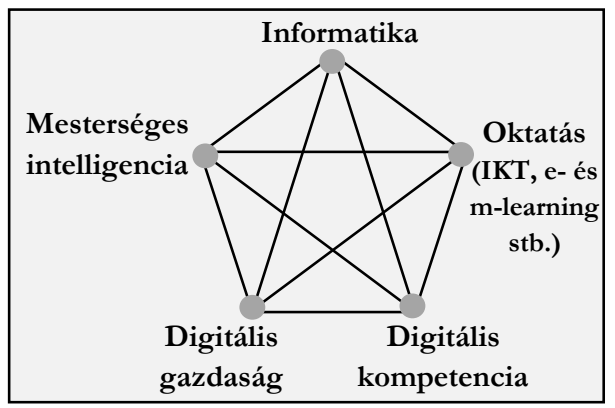

Például az informatika adja azokat a hardvereket, szoftvereket és tudásbázist, amit a felhasználó diákoknak/pedagógu- 
soknak el kell sajátítaniuk, hogy a digitális gazdasághoz szükséges kompetenciákra tegyenek szert, s adott esetben alkotói és/vagy felhasználói és/vagy haszonélvezői lehessenek a mesterséges intelligencia nyúj-totta lehetőségeknek, amelyek többek között az informatikát is érintik - s a kör bezárul...

Egy másik példa: ha erősödik a mesterséges intelligencia szerepe a digitális gazdaságban, akkor ez magával vonja az oktatási rendszer változását (erősödhet az info-kommunikációs eszközök, az elearning, illetve az m-learning alkalmazása), hogy digitális kompetenciákkal ruházza fel a potenciális felhasználókat (végső soron a társadalmat), akik számára biztosítani szükséges a megfelelő informatikai (hardver/szoftver) eszközöket is.

Mindennek következménye, hogy a mesterséges intelligencia interdiszciplináris megközelítésekor minimálisan e komponensekre, s a hozzájuk közvetlenül vagy közvetve kötődő diszciplinákra is nyitottságot szükséges mutatni (lásd még: az MI és a világ kölcsönhatása fejezetet!).

Az MI, mint a privát, köztéri és globális környezet alakitásának/ használatának eszköẓe

Privát szféránkban a mesterséges intelligencia megjelenik a lakberendezésben (Dajkó, 2019d) is (például: kis lakásban gépesítve átrendezhető elemes bútorcsalád, az „okos világítás” technológia stb. formájában), illetve a konyhában is (Net5). Ugyanakkor akár bolygóméretú, globális környezetvédelmi feladatokban is hasznos lehet a mesterséges intelligencia alkalmazása (Szalai, 2019; Net9).

A szúkebb értelemben vett privát szféra, s a legtágabb értelemben vett globális szemlélet között a köztéri, s ezzel együtt a közlekedési problémák orvoslására is alkalmazható lehet a mesterséges intelligencia. Az MI hasznosítható például annak felderítésére, hogy hol van szükség közutak felújításra (Ludvigh, 2019), a közlekedési táblák állapotának ellenôrzésére (Net6), a parkolási problémák kezelésére (Dajkó, 2019c).

A környezetben történő közlekedés tekintetében pedig gondoljunk a mesterséges intelligencia szerepére az önvezérelt járművek - autók (Rosta, 2018a,b; Abu85, 2019), buszok (Rosta, 2018c) hajók (Szalai, 2018a) - létrehozása, a légiforgalomirányítók (Net7) és az űrhajósok segítése (Sarkadi, 2018a) kapcsán.

Az MI, mint az egészségügyet szolgáló eszköz. Kommentár nélkül is „önmagukért beszélő" címekkel találkozhatunk a mesterséges intelligencia sokoldalú egészségügyi felhasználásának témakörében megjelenő populáris cikkek, híradások esetében. Például:

- A Google algoritmusa megmondja, hogy meghalsz-e a kórházban (Dajkó, 2018b)

- Az Accenture új AI-botokat fejlesztett ki betegek számára (IT café, 2018d)

- Mesterséges intelligenciával kutatják a Parkinson-kórt (Szalai, 2018b) 
- AI segít az Alzheimer felfedezésében (Rosta, 2018d)

- A mesterséges intelligencia megtalálja és kivágja a beteg sejtet (Virághalmy, 2019)

- Szeretnéd, hogy ember helyett robot gondozza idős, beteg édesanyádat? (Drajkó, 2019)

- Elon Musk már az agyunkba drótozna számítógépeket (Világi, 2019)

- Agyba ültetett csipekkel turbózzák fel a memóriát (Váczi, 2019)

- Kiváló lehet a bőrrák kiszűrésében a mesterséges intelligencia (Net8)

\section{Az. MI mint múvészeti,}

illetve szórakoztató esz̧özz

$\mathrm{Az}$ internetes hírforrások olvasói információkat kaphatnak arról, hogy a mesterséges intelligencia a múvészetek, illetve a szórakoztató játékok terén is alkalmazhatók lehetnek. Vonatkozó hírek, írások például: „Idén mesterséges intelligencia is indult az Eurovízión. Az Oracle AI és gépi tanulási technológiája írta az idei Eurovíziós Dalfesztivál nem hivatalos himnuszát” (Net10). Vagy: „Itt a neurális beatboxgép, ami slágert csinál a zajokból, amiket kiadsz" (Net11). Ugyancsak zenével kapcsolatos cím: „Személyes ízlésnek megfelelő zenét kreálhat a mesterséges intelligencia?" (Net12). Szerepeljen itt demonstrációként egy-egy példa a mesterséges intelligencia vizuális művészetbeli, illetve irodalmi alkalmazásával kapcsolatban is: „Több mint 400 ezer dollárért ment el a kép, amit egy algoritmus festett" (Czinkóczi, 2018), és „Olyan Harry Potter-történetet írt a mesterséges intelligencia, hogy a rajongók sírva követelik a folytatást" (Net13).

A mesterséges intelligenciával kapcsolatos hírekből tájékozódó olvasók képet alkothatnak arról is, hogy az MI a sakk, póker, Rubik-kocka stb. jellegú játékok vonatkozásában is eredményes lehet. Például: a póker esetében „Elképesztő emberi képességet sajátított el a Facebook mesterséges intelligenciája. A mesterséges intelligencia fejlődése lenyűgöző: már létezik egy szoftver, ami képes blöffölni” (Net14). Vagy: „Ha rosszkor pislog, lemarad arról, ahogy a mesterséges intelligencia kirakja a Rubik-kockát. A Kaliforniai Egyetem kutatói által létre hozott mesterséges intelligencia valamivel több mint egy másodperc alatt forgatta ki az ikonikus játékot” (Net15). Végül egy utolsó ide tartozó példa: „Az UR3 életre kelti Myro-t, a szórakoztató robotot - A Nokinomo francia interaktív design ügynökség létrehozta Myro-t, a szórakoztató robotot" (Net16).

Talán a fentiek jól demonstrálják, hogy a média képes a mesterséges intelligenciával kapcsolatos közvélemény, s attitűd formálására - különösen, ha a híreket is mesterséges intelligencia olvassa fel a nap 24 órájában és 365 napjában (Sarkadi, 2018b). A média tömegek számára képes akár a mesterséges intelligenciával kapcsolatban is ismereteket, érzelmeket, viselkedési mintákat közvetíteni. 


\section{A mesterséges intelligencia és a világ kölcsönhatásának kutatása}

A hatás-orientált megközelités (MI $\leftrightarrows$ Világ) körébe sorolható kutatások egy jelentős része a mesterséges intelligencia térhódításával összefüggő jelenségek megismerésére, predikciójára és/vagy módosítására fókuszál. Másrészt arra, hogy a mindenkori fizikai/szociális környezet (például a rendelkezésre álló nyersanyagbeli, tárgyi, személyi, tudásbeli, illetve társadalmigazdasági-politikai hatások) miként befolyásolják a mesterséges intelligencia kutatását, illetve felhasználását.

A hatás-orientált megközelítés központi kérdése: „Milyen (kölcsön)hatás van a világ és a mesterséges intelligencia technológia elterjedése között, s miként befolyásolható ez a hatás?".

Demonstrációként szerepeljen itt néhány
kiragadott példa:
Riek, Adams és Robinson (2011) a robo-
tokat pozitív/negatív színben feltüntető
filmek megtekintésének hatását vizsgálta a
robotokkal szembeni attitűd alakulásával
kapcsolatban.
MacDorman, Vasudevan és Ho (2009) a
japán emberek ,robotmániáját” vizsgálta.
Bartneck és tsai (2007) a kultúraközi ha-
tásokat vizsgálta a robotokkal szembeni
attitűdök kapcsán.
Riek és tsai (2010) az arabok humanoid
robotok iránti attitúdjére fókuszáltak kuta-
tásukban.

A hatás-orientált megközelítéshez közvetlenül kapcsolódó jellemző tudományterületek: pszichológia, szociológia, jog, politológia, gazdaságtudomány, filozófia, történelem és pedagógia. Jellegzetes kutatási témakörök lehetnek e tudományágak szempontjából:

\section{Pszichológiai kölcsönhatások kutatása}

A mesterséges intelligenciával kapcsolatos sztereotípiák, attitűdök, az ember-gép interakció kutatása tipikusan pszichológiai kutatási terület (amit nem kizárólag pszichológusok múvelnek). A pszichés folyamatok algoritmizálási/programozási lehetősége, s modellezése is számot tarthat pszichológiai érdeklődésre. Egy ritkábban előforduló pszichológiai vonatkozású témát vett fel Freeland (2018) „Kellene-e aggódnunk a kibernetikus mentális betegségek miatt?" címû írásában. Felvetése szerint ugyanis, ha egyszer valóban sikerül a humán psziché gépi modelljét létrehozni, akkor az emberekéhez hasonlító gépi mentális betegségekre is számítani lehet.

A sci-fi irodalom és filmek révén a laikus közönség is találkozik-e felvetéssel, az „őrült robot” motívumával (Freeland, 2018) - például:

HAL 9000 robot az egymásnak ellentmondó parancsok okozta ellentmondás (kvázi robotikus kognitív disszonancia) megszüntetéseként megöli az űrhajó legénységét Arthur C. Clarke 1968-as „A Space Odyssey” című (Magyarországon: „2001. Ürodüsszeia”-ként megismert) művében.

Marvin, a szuperintelligens robot depressziós tüneteket mutat Douglas Adams ,The Hitchhiker's Guide to the Galaxy” (magyarul „Galaxis útikalauz stopposoknak”) című alkotásában. 
A Roy Batty nevü humanoid robot egyrészt poszttraumás stressz szindróma, másrészt „halálfélelem” tüneteit mutatja Philip Dick 1968-as „Do Androids Dream of Electric Sheep?" (Ámodnak a robotok elektromos bárányokkal?) történetében, ami a magyar mozikban „Szárnyas fejvadász” (eredetileg „Blade Runner”) címen volt látható.

Isaac Asimov robotregényeiben, sci-fi novelláiban pedig nemcsak a meghibásodott robotok jelennek meg, hanem a robotpszichológia is.

\section{Szociológiai kölcsönhatások kutatása}

Hogyan hat a társadalmakra, a családra, a gyermekvállalásra, a foglalkoztatásra, a társadalmi mobilitásra a mesterséges intelligencia térhódítása? Az AI \& Society című folyóirat például kifejezetten erről az oldalról járja körül a mesterséges intelligencia témakörét (a lap ezen a weboldalon található meg: https://rd.springer.com/ journal/146).

\section{Jogi kölcsönhatások kutatása}

A mesterséges intelligenciára vonatkozó jogszabályozástól a mesterséges intelligenciát célként vagy eszközként érintő bűncselekményeken át a mesterséges intelligencia joggyakorlatban, például ügyvédi munkában való térhódításáig (Sarkadi, 2017) terjedhet a vonatkozó kutatások köre. Figyelemre méltó például, hogy egy MI az ügyek 79\%-ában helyesen jósolta be, hogy milyen ítélet várható (Horváth, 2016). Izgalmas kérdés az is, hogy (tekintve, a paragrafusok és az eljárásrendek rögzített, sok esetben adott algoritmus alapján haladó módját) robotokra lehet-e bízni a bíróságokat valaha (Horváth, 2018a).

Vagy: a mesterséges intelligenciával vezérelt járművekkel okozott esetleges balesetek jogi következményeként például olyan jogi szabályozásra van szükség, ami egyértelmûvé teszi, hogy ki a felelős: az ötletgazda, a programozó, a gyártó, a forgalmazó, a jármú tulajdonosa, vagy a mesterséges intelligencia...? Vö. Pokol (2018), Rajczy (2019), Z. Karvalics (2015).

Végül: napjainkban arra is van precedens, hogy mesterséges intelligenciát imitáló, minimálbérért dolgozó élőszemélyekkel csapják be ügyfeleiket egyes, magukat MI-vel reklámozó cégek (Herczeg, 2018).

\section{Filozófia-MI \\ kölcsönhatásra vonatkoró kutatások}

A létezés általános problémájától kezdve etikai megfontolásokon át vallásfilozófiáig terjedő felvetések sorára kell a filozófiának is választ keresnie az MI-vel kapcsolatban. A mesterséges intelligencia fejlesztői körében napjainkban is tartó etikai vita egyik központi kérdése például: mi történik, ha rossz kezekbe kerülnek eredményeik (Horváth, 2018b). Kérdés, hogy szükséges és etikus-e önkorlátozás bevezetése az MI kutatás, fejlesztés és publikációk terén vagy sem? A kérdés súlyát jelzi, hogy a mesterséges intelligencia és etika kapcsolata 2018-ban már az Európai Bizottság (EB) keretében egyházakkal, vallá- 
sokkal és világnézeti szervezetekkel folytatott egyeztetésnek is központi témaköre lett - lásd az Európai Bizottság (2018) sajtóközleményét. Az EB szakértői bizottsága 2019-ben etikai irányelveket fogalmazott meg a megbízható MI-vel kapcsolatban (lásd: AI HLEG, 2019).

\section{Pedagógia-MI}

\section{kölcsönhatásra fókuszáló kutatások}

Miként nevelhetôk, oktathatók a mesterséges intelligencia használatára az újabb és újabb generációk? Milyen hatása lesz a mesterséges intelligenciának a tananyagra, az oktatás személyes vagy elektronikus formáira, a pedagógusképzésre, az iskolarendszerre (vö: Mező és Mező, 2019)? Hogyan függ össze a digitális kompetencia, az info-kommunikációs eszközök oktatási alkalmazása, az e-leraning és az mlearning a mesterséges intelligenciával? Másrészt: milyen pedagógiai elvek érvényesíthetôk majd az olyan robotok esetében, amelyek nevelés, oktatás révén lesznek programozhatók? Mi az a típusú tudás, ami „,betölthetô” lesz az MI memóriájába, s miféle ismeretanyag lesz az, amire nevelni-oktatni kell/lehet majd az MI-t? Milyen újszerú és/vagy klasszikus pedagógus kompetenciákkal kell rendelkeznie egy robotpedagógusnak (egy olyan mesterséges intelligenciának, akinek emberek, vagy más MI-k nevelése-oktatása a feladata), illetve egy robotokat nevelö-oktató Homo Sapiens Sapiens pedagógusnak?

\section{Politológiai hatások kutatása}

A mesterséges intelligencia manapság is hatást gyakorol a politikára, és a politikai döntések, események is befolyásolják a mesterséges intelligencia kutatások támogatottságát.

A mesterséges intelligenciának hatása lehet például a foglalkoztatáspolitikára (például: munkahelyteremtő, vagy munkanélküliséget generáló jelenség-e a mesterséges intelligencia?), a gazdaságpolitikára és ezzel összefüggésben a nemzetgazdasági mutatókra, a népesedéspolitikára (például: növeli vagy csökkenti a népesedéspolitikai mutatókat az MI bevezetése a gazdaságba, a hétköznapokba?), az oktatáspolitikára (lásd: a korábbi pedagógiai felvetéseket is), vagy az általában véve vett bel- és külpolitikára, stb. Sőt: a politikai választásokra is. Rubio és Lastra-Anadon (2019) által végzett, 2576 európai (francia, német, ír, olasz, spanyol, holland, brit) 18-99 éves felnőtt válaszadóra vonatkozó felmérés eredménye szerint a kérdezettek negyede jobban bízik a mesterséges intelligenciában, mint egy politikusban.

A mindenkori politikai vezetés mesterséges intelligencia kutatásához füződő attitűdje pedig hatással lehet e kutatások ösztönzésére vagy éppen ellehetetlenítésére. Napjainkban Magyarországon és világszerte is a mesterséges intelligencia kormányzati szintű támogatottsága a jellemző. Az ok voltaképpen egyszerű: az „MI $\leftrightarrows$ világ” kölcsöhatás politikai, társadalmi, gazdasági, időbeliségét tekintve pedig történelmi jelentőséggel bír! 


\section{Hadtudomány-MI}

\section{kölcsönhatás kutatása}

Mint Csutak (2018, 34. o.) írja: „Az első öbölháború legendás amerikai parancsnoka, Norman Schwarzkopf tábornok elhíresült bon mot-ja volt 1991-ből, hogy nyavalyás számítógépekkel nem lehet csatát vívni, ellenben 2018-ban kis túlzással kijelenthetjük, hogy a mai posztmodern korban már nem lehet - vagy csupán nagyon korlátozott módon - számítógépek igénybevétele nélkül komoly és korszerű hadviselést folytatni. Az amerikai tudományos-fantasztikus irodalom világából 1982 óta kölcsönvett kibertér fogalom és a rövidesen hozzákapcsolódó kiberhadviselés ma már érzékelhető valóság és új alkalmazott hadviselési forma." A kiberhadviselés dióhéjban a számítógépes alkalmazások és rendszerek elleni támadások (azok előkészítésére és kivitelezésére), s ezek elhárítására vonatkozik. Tekintve, hogy a mesterséges intelligencia is elektronizált, számítógépes környezetben létezik, így fejlődése óhatatlanul hat a kiberhadviselésre is, és viszont. Mondhatni, a Clausewitz-féle ,a háború a politika folytatása más eszközökkel" megállapítás MI verziója „,a háború a politika folytatása háborús MI eszközökkel” lehet a jövőben.

Ide kívánkozik egy, e tanulmányban már megszokott sci-fi irodalmi, filmes utalás: a Terminátor (a címadó fóhős is robot!) című filmben a Skynet (egy katonai védelmi célokra tervezett mesterséges intelligencia) program öntudatra ébredt, s az emberiség ellen fordult. Ennek jelentősége abban van, hogy az MI katonai alkalmazá-

\begin{abstract}
sát befolyásoló társadalmi, politikai közvélemény mögötti tömeg az esetek döntő részében nem az MI terén magasan képzett személyekből áll, hanem inkább az MI-vel szembeni attitűdjét formáló tapasztalatait populáris irodalmi és/vagy filmélményekből, többé vagy kevésbé megbízható (olykor teljesen megbízhatatlan) híradásokból, közösségi média forrásokból szerzi. Az MI-vel kapcsolatos társadalmi attitűd formálásában az említett médiának jelentős szerepe van, amit az MI-t hadtudományi, politikai célra alkalmazók sem hagyhatnak figyelmen kívül.
\end{abstract}

A mesterséges intelligencia nem csak stratégiai tervezői (adatelemzői, döntés előkészítési, kockázatelemzési stb.) szinten vehet részt a hadviselésben, hanem taktikai szinten is (gondoljunk a harci robotok, önvezérelt felderítő/támadó drónok, hajók, szárazföldi jármúvek, rakéták, lövedékek, lőfegyverek, a katonai célú adatbányász szoftverek stb. világára). Azonban mint arra fent már utaltunk, a túl okos fegyverek ellen iparági összefogás született (Dajkó, 2018a).

A hadtudomány és az MI viszonyát tekintve fontos kutatási terület lehet, annak feltérképezése, hogy milyen biztonságpolitikai, kiber-védelmi kihívásokkal szembesülhet egy olyan ország (vagy bármilyen célcsoport), amely szélsőséges mértékben áll át az MI gazdaságra. Ilyen esetben az MI kibertámadások célpontjává válhat, s megsemmisítése vagy hibás (legalábbis a fenntartói szándékának nem megfelelő) működésre késztetése totális összeomláshoz, káoszhoz vezethet. A központi szerepet játszó MI kiiktatása vagy múködési 
zavarának előidézése tehát olyan hatásalapú múveletnek tekinthető, amely akár viszonylag csekély befektetéssel (számítógépes vírussal) is sorsdöntő következményekkel járhat a múvelet vagy akár az egész háború kimenetét tekintve.

\section{Néhány további példa a világ-MI}

kölcsönhatásra vonatkozó kutatások terén

Gazdaságtudomány: milyen gazdasági következménye van az MI bevezetésének, vagy figyelmen kívül hagyásának? Fordítva: hogyan hat a gazdaság a mesterséges intelligenciára vonatkozó kutatásokra többek között azok finanszírozására?

Történelemtudomány: a mesterséges intelligencia segítséget jelenthet a korabeli szöveges források fordításában, írások megfejtésében, képi és szöveges információkat érintő adatbányászatban. A történészek pedig idővel az MI történetiségére fókuszálhatnak.

Irodalomtudomány, média, filmmúvészet: különösen a tudományos-fantasztikus müfaj lehet megtermékenyítő hatású a mesterséges intelligenciát célként/eszközként tekintő kutatók számára. Az irodalmi müvek, filmek alkotóinak pedig a mesterséges intelligencia nyújthat ihletet adó témát. Lásd még: Tolcsvai (2018).

Matematika: a mesterséges intelligencia kutatói a matematikai alapokat kaphatják e tudományág művelőitől, míg a matematikusok hasznos segédeszközre tehetnek szert a mesterséges intelligencia alkalmazásakor.
Nyelvtudomány: beszéd-, szövegfelismeró MI-k fejlesztésében vehetnek részt a nyelvtudomány képviselői. A mesterséges intelligencia nyelvészeti alkalmazása - $\mathrm{s}$ általában fogalomhasználata - visszahat a nyelvre, annak tudományos kutatására is.

\section{Zárógondolatok}

A mesterséges intelligencia tudományos kutatások célja és eszköze is lehet, ugyanakkor tudományos érdeklődésre tarthat számot a világra gyakorolt (kölcsön)hatása is.

E tanulmány rámutatott arra, hogy a mesterséges intelligencia témakör oly sokrétű, hogy minden tudományterület, illetve művészeti ág képviselője csatlakozhat hozzá valamilyen szálon.

Célja szerint e cikk az említett csatlakozásra ösztönözni is szeretné Olvasóit! Egyrészt azzal, hogy a fentiekben nagyszámú konkrét példán keresztül mutattuk be, hogy különböző diszciplinák felől, miként közelíthetünk a mesterséges intelligencia kutatásához, felhasználáshoz. Másrészt a Szerzô (a tanulmány elején megadott e-mail címén keresztül történő kapcsolatfelvétel után) ingyenes témaválasztási konzultációt, tanácsadást is biztosít az MI-vel még éppen ismerkedő kutatók, mûvészek számára.

\section{Irodalom}

1536/2016. (X. 13.) Korm. határozat a köznevelési, a szakeképzési, a felsöoktatási és a 
felnöttképzési rendsz̧er digitális átalakitásáról és Magyarország Digitális Oktatási Stratégiájáról

1168/2019. (III. 28.) Korm. határozat $A$ „S rakképrés 4.0 - A sqakeképrés és felnöttképzés megújitásának középtávú szakmapolitikai stratégiaja, a szak.képzési rendszer válasza a negyedik ipari forradalom kihivásaira" címü stratégia elfogadásáról és a végrehajtása érdekében szülkséges intézkedésekröl

1341/2019. (VI. 11.) Korm. határozat a Digitális Kompetencia Keretrendszer fejlesztéséröl és bevezetésének lépéseiröl

Abu85 (2019): Saját hardverrel venné be az. önvezetó" autók piacát a Tesla. Letöltés: 2019.06.22. Web: https://m.prohard ver.hu/hir/sajat_hardverrel_venne_be _onvezeto_auto_piac.html

AI HLEG (High-Level Expert Group on AI, 2018): A definition of AI: Main capabilities and scientific disciplines. Letöltés: 2019.07.02. Web: https://ec. europa.eu/futurium/en/ai-allianceconsultation/guidelines\#Top

AI HLEG (High-Level Expert Group on AI, 2019): Ethics Guidelines for Trustworthy AI. Letöltés: 2019.07.10. Web: https://ec.europa.eu/futurium/en/aialliance-consultation/guidelines\#Top

Altrichter Márta, Horváth Gábor, Pataki Béla, Strausz György, Takács Gábor és Valyon József (2006): Neurális Hálózatok. Panem Könyvkiadó Kft., Budapest.

Antalné Miss Lilla (2019): Válj digitális pedagógussá most. Továbbképrés pedagógusok- nak öt órában. T-Systems Magyarország Zrt., Budapest.

Bartneck, C., Suzuki, T., Kanda, T. and Nomura, T. (2007): The influence of people's culture and prior experiences with Aibo on their attitude towards robots. AI and Society, 21:217-230, 2007. doi: 10.1007/s00146-006-0052-7

Birkás Péter (2019): Magyar tananyag segit, hogy a diákok elsajátithassák a jövöt alakitó technológiákat. Letöltés: 2019.06.15. Web: https://24.hu/tech/2019/06/ 14/makerspace-hu-tananyag-dokkkonferencia/

Bolcsó Dániel (2019): A kiberbáborúban minden cég célpont. Letöltés: 2019.06.30. Web: https://index.hu/techtud/2019 /06/28/kiberbiztonsag_kiberhirszerze s_black_cell_recorded_future_adatlop as_adatszivargas/

Cawsey, A. (2002): Mesterséges intelligencia Alapismeretek. Panem, Budapest.

Csutak Zsolt (2018): Új idők új hadviselése - kognitív biztonság az információs és a kiberhadviselés korában. Honvédségi Szemle, 2018/5. 33-45.

Crowder, J. A. \& Friess, Sh. (2012): Artificial Psychology: The Psychology of AI. Conference paper (March 2012).

Czinkóczi Sándor (2018): Több mint 400 ezer dollárért ment el a kép, amit egy algoritmus festett. Letöltés: Web: https://444.hu/2018/10/25/tobbmint-400-ezer-dollarert-ment-el-a-kepamit-egy-algoritmus-festett

Dajkó Pál (2018a): Iparági összefogás a túl okos fegyverek ellen. Letöltés: 2018.07.20. 
Web: https://itcafe.hu/hir/ai_mi_ fegyver_nyilt_level.html

Dajkó Pál (2018b): A Google algoritmusa megmondja, hogy meghalsz-e a kórbáz̧ban. Letöltés: 2019.01.08. Web: https:// itcafe.hu/hir/google_ai_mi_korhaz.ht $\mathrm{ml}$

Dajkó Pál (2019a): Még mindig sereghajtók vagyunk a digitális versenyképesség terén. Letöltés: 2019.06.30. Web: https:// itcafe.hu/hir/eu_desi_2019.html

Dajkó Pál (2019b): Finnország az AI tanitásában látja a jövót. Letöltés: 2019.03.11. Web: https://itcafe.hu/ hir/ai_mi_finnorszag.html

Dajkó Pál (2019c): Parkolórobotok a repülótéren. Letöltés: 2019.06.22. Web: https://itcafe.hu/hir/parkolas_robot. $\mathrm{html}$

Dajkó Pál (2019d): Robotizált lakással ujit a₹ IKEA. Letöltés: 2019.06.10. Web: https://itcafe.hu/hir/ikea_lakas_robo t.html

Drajkó Zsombor (2019): Szeretnéd, hogy ember helyett robot gondozza idós, beteg édesanyádat? Letöltés: 2019.06.21. Web: https://qubit.hu/2019/02/19/szeretn ed-hogy-ember-helyett-robotgondozza-idos-beteg-edesanyadat

Delcker, Janosch (2019): Finland's grand AI experiment. Inside Finland's plan to train its population in artificial intelligence. Letöltés: Web: https://www.politico .eu/article/finland-one-percent-aiartificial-intelligence-courses-learningtraining/\#print
Digitális Jólét Program (DJP): DJP Digitalizációs fogalomtár. letöltés: 2019.07.20. Web: https://djp.startupguide.hu/

Európai Bizottság (2018): Mesterséges intelligencia: a Bizottság megvitatja az etikeai és társadalmi hatásokat világnézeti szervezetekkel (sajtókö̊llemény). Letöltés: 2019.06.22. Web: http://europa.eu/ rapid/press-release_IP-18-4160_hu. htm

Freeland, B. (2018): Should We Be Worried About Cybernetic Mental Illness? Letöltés: 2019.06.22. Web: https://medium. com/@benfreeland/should-we-beworried-about-cybernetic-mentalillness-97a97460f604

Futó Iván (szerk.)(1999): Mesterséges intelligencia. Aula Kiadó, Budapest.

Gubán Miklós (2014): Mesterséges intelligencia. Budapest: Budapesti Gazdasági Főiskola. Letöltés: 2019.07.20. Web: https://www.tankonyvtar.hu/hu/tarta lom/tamop412A/2011-0003_02_ mesterseges_intelligencia/osszefoglala s_3Ivom3STccvrnRd3.html

Herczeg Márk (2018): Egyes MI-cégeknél magukat mesterséges intelligenciának tettetô emberek dolgoznak. Letöltés: 2018.07.06. Web: https://444.hu/ 2018/07/06/egyes-mi-cegeknelmagukat-mesterseges-intelligencianaktetteto-emberek-dolgoznak

Horváth Bence (2016): Egy AI egész jó arányban jósolta meg emberi jogi ügyek. kimenetelét. Letöltés: 2018.03.11. Web: https://444.hu/2016/10/24/egy-ai- 
egesz-jo-aranyban-josolta-meg-emberijogi-ugyek-kimenetelet

Horváth Bence (2018a): Rá lehet-e bizni robotokra a biróságokat? Letöltés: 2018. 12.10. Web: https://444.hu/2018/ 11/19/ra-lehet-e-bizni-robotokra-abirosagokat

Horváth Bence (2018b): Az. AI-fejlesztöok között is egyre többen félnek attól, hogy rossz. kezekbe kerülbetnek az eredményeik. Letötés: 2018.12.27. Web: https:// 444. hu/2018/12/09/az-ai-fejlesztokkozott-is-egyre-tobben-felnek-attolhogy-rossz-kezekbe-kerulhetnek-azeredmenyeik

IT café (2018a): Az emberek többsége elfogadna utasitásokat robottól is a munkahelyén. Letöltés: 2019.06.25. Web: https://itcafe.hu/hir/oracle_ai_felmer es.html

IT café (2018b): A fiatalok nem félnek használni az. AI-t. Letöltés: 2018.12.03. Web: https://itcafe.hu/hir/honor_ai_ felmeres.html

IT café (2018c): Majdnem minden kisiskolás használ okoseszközt. Letöltés: 2019. 01.10. Web: https://itcafe.hu/hir/nn_ gyerekek_felmeres_okoseszkoz.html

IT café (2018d): Az.Accenture üj AI-botokat fejlesztett ki betegek számára. Letöltés: 2019.01.20. Web: https://itcafe.hu/ hir/accenture_ella_ethan_bot.html

IT café (2019a): Az MI bajtja a digitális gazdaságot. Letöltés: 2019.01.11. Web: https://itcafe.hu/hir/huawei_gci_fel meres.html
IT café (2019b): Újitó ötleteket várnak a pedagógusok Digitális Módszertárába. Letöltés: 2019.07.20. Web: https:// itcafe.hu/hir/digitalis_modszertar_te mpus.html

IT café (2019c): Végre kapnak jelentós állami támogatást a robotépitő diákok. Letöltés: 2019.05.12. Web: https://itcafe.hu/hir /wro_robotika_magyarorszag.html

Ludvigh Károly (2019): Mesterséges intelligenciával deritik fel a közúti veszélyeket Angliában. Letöltés: 2019. július 26. Web:

https://totalcar.hu/magazin/hirek/20 19/07/24/mesterseges_intelligenciava 1_deritik_fel_a_kozuti_veszelyeket_an gliaban/amp.

MacDorman, K., Vasudevan, S. and Ho, C. (2009): Does Japan really have robot mania? Comparing attitudes by implicit and explicit measures. $A I$ \& Society, 2009, 23(4):485-510 doi: 10.1007/s00146-008-0181-2

Magyarorsáa Digitális Oktatási Stratégiája (2016). Letöltés: 2019.01.22. Web: https://www.kormany.hu/download/ a/59/d0000/Magyarorsza $\% C C \% 81 \mathrm{~g}$ $\% 20$ Digita $\%$ CC $\% 81$ lis $\% 20$ Oktata $\% C$ C $\% 81$ si $\% 20$ Strate $\% C C \% 81$ gia $\% C C \%$ 81 ja.pdf

Mesterséges intelligencia elektronikus almanach (2011). Letöltés: 2019.07.01. Web: https://www.tankonyvtar.hu/en/tarta lom/tamop425/0026_MI_almanach_ 4_4/index.html 
Mesterséges Intelligencia Koalíció. Letöltés: 2019.07.10. Web: https://digitalisjolet proram.hu/hu/tartalom/mestersegesintelligencia-koalicio

Mező Ferenc és Mező Katalin (2019): Az OxIPO-modell - az interdiszciplináris kutatások egy lehetséges értelmezési kerete. OxIPO - interdiszciplináris tudományos folyóirat, 2019/1, 9-21. doi: 10.35405/OXIPO.2019.1.9

Microsoft New Center (2019): A mesterséges intelligencia tudásukat osztották meg civil szervezetek.kel a startupok Budapesten. Letöltés: 2019.06.10. Web: https:// news.microsoft.com/hu-hu/2019/06/ 05/a-mesterseges-intelligencia-tudasukat-osztottak-meg-civil-szervezetekkela-startupok-budapesten/

Net1: A mesterséges intelligencia hatása az ipari forradaloméhoz mérhetó. Letöltés: 2019. 01.12. Web: http://m.sg.hu/cikk. php?cid=133280\&cim =a_mesterseges _intelligencia_hatasa_az_ipari_forradal omehoz_merhet

Net2: Informatikai gigafelvásárlás zajlott le: 34 milliárdért vett céget az. IBM. Letöltés: 2019.07.10. Web: https://www. portfolio.hu/vallalatok/it/informatikai -gigafelvasarlas-zajlott-le-34-milliardert -vett-ceget-az-ibm.330573.html?amp

Net3: Mekekora magyar informatikai óriás jön létre? Letöltés: 2019.07.10. Web: https://www.portfolio.hu/vallalatok/t elekom/mekkora-magyar-informatika i-orias-jon-letre.330501.html?amp

Net4: Digitális oktatási programot indit a $T$ Systems. Letöltés: 2019.06.10. Web: https://www.origo.hu/techbazis/201

90605-t-systems-modern-iskola-

program.html

Net5: A konyhában is megjelent a mesterséges intelligencia. Letöltés: 2019.07.17. Web: https://sg.hu/cikkek/it-tech/137151/ a-konyhaban-is-megjelent-a-mester seges-intelligencia

Net6 (2019): Street View képeken ellenörzi a táblákat a mesterséges intelligencia. Letöltés: 2019.06.22. Web: https://bitport. $\mathrm{hu} /$ street-view-kepeken-ellenorzi-atablakat-a-mesterseges-intelligencia

Net7: Mesterséges intelligencia segitheti a légiforgalom-irányitókat. Letöltés: 2019.05.01. Web: http://m.sg.hu/ cikk.php?cid=135879\&cim = mesterseg es_intelligencia_segitheti_a_legiforgalo m_iranyitokat

Netx8: Kiváló lehet a börrák kiszürésében a mesterséges intelligencia. letöltés: 2019. 05.01. Web:http://m.sg.hu/cikk. php? cid=135984\&cim=kivalo_lehet_a_b_r rak_kisz_reseben_a_mesterseges_intel ligencia

Net9: A mesterséges intelligencia óriási segitség a dekarbonizációban. Letöltés: 2019.07.23. Web: https:/ /ajovoenergiaja.blog.hu/ 2019/07/22/a_mesterseges_intelligen cia_oriasi_segitseg_a_dekarbonizaciob an

Net10: Idén mesterséges intelligencia is indult az. Eurovizión. Az Oracle AI és gépi tanulási technológiája irta az idei Euroviziós Dalfesztivál nem hivatalos himnuszát. Letöltés: 2019.06.10. Web: http://www.techno krata.hu/tudomany/2019/05/16/iden 
-mesterseges-intelligencia-is-indult-azeurovizion/

Net11: Itt a neurális beatboxgép, ami slágert csinál a zajokból, amiket kiadsz. Letöltés: 2018.09.01. Web: https://444.hu/ 2018/08/07/itt-a-neuralis-beatbox gep-ami-slagert-csinal-a-zajokbolamiket-kiadsz

Net12: Személyes izlésnek megfelelö zenét kreálhat a mesterséges intelligencia? Letöltés: 2018.12.10. Web: http://m.sg.hu/ cikk.php?cid $=134075 \&$ cim $=$ szemelyes _izlesnek_megfelel_zenet_krealhat_a_ mesterseges_intelligencia

Net13: Olyan Harry Potter-történetet irt a mesterséges intelligencia, hogy a rajongók sírva követelik a folytatást. Letöltés: 2018.12.03. Web: https://mivoltma. 444.hu/2017/12/14/olyan-harry-pot ter-tortenetet-irt-a-mesterseges-intelli gencia-hogy-a-rajongok-sirva-kovetelik -a-folytatast?_ga $=2.64115308 .213349$ 0847.1564015914-431422869.156401 5914

Net14: Elképesz̨tó emberi képességet sajátitott el a Facebook mesterséges intelligenciája. A mesterséges intelligencia fejlödése lenyügözó: már létezile egy szoftver, ami képes blöffölni. Letöltés: 2019.07.15. Web: https://fe mina.hu/terasz/mesterseges-intelligen cia-fejlodese/amp

Net15: Ha rosszkor pislog, lemarad arról, ahogy a mesterséges intelligencia kirakja a Rubik-kockát. A Kaliforniai Egyetem kutatói által létre bozott mesterséges intelligencia valamivel több mint egy másodperc alatt forgatta ki az ikonikus játékot. Letöltés: 2019.07.17. Web: https://hvg.hu/tudomany/20190716_ mesterseges_intelligencia_rubik_kocka _kaliforniai_egyetem

Net16: Az UR3 Életre Kelti Myro-t, a szórakoztató robotot - A Nokinomo francia interaktiv design ügynökség létrehozta Myrot, a szórakoztató robotot. Letöltés: 2019.03.11. Web: http://www.technokrata.hu/tudomany/2019/01/30/azur3-eletre-kelti-myro-t-a-szorakoztatorobotot/

Pokol Béla (2018): A mesterséges intelligencia társadalma. Kairosz Kiadó, Budapest.

Rajczy István (2019): Mesterséges intelligencia. Infojegyzet. Országgyűlés Hivatala, Budapest. 1-4. o. Letöltés: 2019.07.21. Web: https://www.par lament.hu/documents/10181/178921 7/Infojegyzet_2019_11_mesterseges_i ntelligencia.pdf/6ec90247-a26c-30edbe63-c4e3f052b835

Rácz Gergő (2019): Jegybankárok gondolatait is olvassa a mesterséges intelligencia. Könynyebben kiszámitható a monetáris politika iránya gépi segitséggel. Letöltés: 2019. 06.22. Web: https://magyarnemzet.hu /gazdasag/jegybankarok-gondolataitis-olvassa-a-mesterseges-intelligencia7024541/

Riek, L. D., Adams, A. \& Robinson, P. (2011). Exposure to Cinematic Depictions of Robots and Attitudes Towards Them. Lab Report. Cambridge: Cambridge (UK): University of Cambridge.

Riek, L. D., Mavridis, N., Antali, S., Darmaki, N., Ahmed, Z., Al-Neyadi, 
M. and Alketheri, A. (2010): Ibn Sina steps out: Exploring Arabic attitudes toward humanoid robots. In In Proc. of The Second Int'l Symposium on New Frontiers in Human-Robot Interaction at AISB 2010, 2010

Rosta Gábor (2018a): Telefonnal vezethetnénk a Ford autóit. Letöltés: 2019.06.22. Web: https://itcafe.hu/hir/telefonnal _vezethetnenk_a_ford_autoit.html

Rosta Gábor (2018b): Chiptuninggal javulhat a Tesla robotpilótája. Letöltés: 2019.01. 10. Web: https://itcafe.hu/hir/chip tuninggal_javulhat_a_tesla_robotpilota ja.html

Rosta Gábor (2018c): Maguktól mennek Osló busqai. Letöltés: 2019.06.25. Web: https://itcafe.hu/hir/maguktol_menn ek_oslo_buszai.html

Rosta Gábor (2018d): AI segít az Alzheimer felfedezésében. Letöltés: 2019. 01.12. Web: https://itcafe.hu/hir/ai _segit_az_alzheimer_felfedezeseben.ht $\mathrm{ml}$

Rubio, D. \& Lastra-Anadon, C. X. (2019): European Tech Insights 2019. Mapping European Attitudes to Technological Change and Its Governance. Madrid: Center of the Governance of Change. Letöltés: 2019.07.20. Web: http://docs.ie.edu/ cgc/European-Tech-Insights-2019.pdf

Sarkadi Zsolt (2017): Egyre több amerikai és brit ügyvédi iroda használ algoritmusokat a gyakornokok és ügyvédjelöltek belyett. Letöltés: 2018.03.11. Web: https://444. hu/2017/05/06/egyre-tobb-amerikaies-brit-ugyvedi-iroda-hasznal-algorit musokat-a-gyakornokok-es-ugyvedje loltek-helyett

Sarkadi Zsolt (2018a): Ő itt CIMON, a mesterséges intelligencia, aki ürhajósokat segit majd a Nemretközi Ürállomáson. Letöltés: 2019.01.21. Web: https://444.hu/ 2018/06/29/o-itt-cimon-a-mesterse ges-intelligencia-aki-urhajosokat-segitmajd-a-nemzetkozi-urallomason

Sarkadi Zsolt (2018b): Mesterséges intelligencia olvasta a hireket a kinai hirügynökségnél. Letöltés: 2018.12.03. Web: https:// 444.hu/2018/11/09/mesterseges-in telligencia-olvasta-a-hireket-a-kinaihirugynoksegnel

Szabó Dániel (2019): A bankok már nem a pénzre vigyáznak leginkább. Letöltés: 2019.06.10. Web: https://www.napi. hu/tech/a_bankok_mar_nem_a_penzre _vigyaznak_a_leginkabb.685511.html

Szakképzés 4.0 - A sqakképzés és felnöttképrés megújitásának köréptávú sqakmapolitikai stratégiája, a szakeképzési rendszer válasza a negyedik ipari forradalom kibivásaira. Letöltés: 2019.07.01. Web: file: // /F:/KFSt $\%$ C3\%BAdi $\% \mathrm{C} 3 \% \mathrm{~B} 3 /$ KFS\%20LAPOK/Mesters\%C3\%A9g es\%20intelligencia/MI_2019_1/MFta nulm $\% \mathrm{C} 3 \%$ A1 ny $/$ Szakk $\% \mathrm{C} 3 \% \mathrm{~A} 9 \mathrm{pz}$ $\% \mathrm{C} 3 \% \mathrm{~A} 9 \mathrm{~s} \% 204-0-$ strat $\%$ C $3 \%$ A9gia.pdf

Szalai Péter (2018a): Újabb lépés az önvezetö hajók irányába. Letöltés: 2019.01.10. Web: https://itcafe.hu/hir/intell-rollsroyce_hajo.html

Szalai Péter (2018b): Mesterséges intelligenciával kutatják a Parkinson-kórt. Letöltés: 
2019.01.08. Web: https://itcafe.hu/ hir/ai_parkinson.html

Szalai Péter (2019): A mesterséges intelligencia ij alapokra helyezheti a környezetvédelmet. Letöltés: 2019.03.11. Web: https://it cafe.hu/hir/mesterseges_intelligencia_ kornyezetvedelem.html

Szepesi Anita (2019): Mesterséges intelligencia: fontos bejelentést tett Palkovics. Letöltés: 2019.06.22. Web: https://www. napi.hu/magyar_gazdasag/mesterse ges_intelligencia_fontos_bejelentest_ tett_palkovics.686573.html

Tolcsvai Nagy Gábor (2018): A bumán tudományok és a gépi intelligencia. Gondolat Kiadó, Budapest.

Váczi István (2019): Agyba ültetett csipekkel turbózzák fel a memóriát. Letöltés: 2019. 06.22. Web: https://g7.hu/elet/2019 0616/agyba-ultetett-csipekkel-turboz zak-fel-a-memoriat/

Világi Máté (2019): Elon Musk már az. agyunkba drótozna számitógépeket. Letöltés: 2019.07.18. Web: https://index. hu/techtud/2019/07/17/neuralink_a gyhoz_kapcsol_szamitogepet/amp

Virághalmy Sarolta (2019): A mesterséges intelligencia megtalálja és kivágja a beteg sejtet. Letöltés: 2019.07.16. Web: https://www.vg.hu/kozelet/technolo gia-tudomany/a-mesterseges-intelli gencia-megtalalja-es-kivagja-a-betegsejtet-1632002/

Z. Karvalics László (2015): Mesterséges intelligencia - a diskurzusok újratervezésének kora. InformációsTársadalom, XV. évf. (2015) 4.szám, 7-41. o. doi: 10.22503/inftars.XV.2015.4.1 


\title{
GONDOLATOK A MESTERSÉGES INTELLIGENCIA, A GÉPI TANULÁS KAPCSÁN
}

\author{
Szerző: \\ Gyarmati Péter (PhD, Prof.Emeritus) \\ Simonyi Professor for the Public \\ Understanding of Science and Professor of \\ Mathematics on the Computer Science
}

Szerző e-mail címe:

gyarmati@gyarmati.dr.hu

\author{
Lektorok: \\ Vámos Tibor (Prof. Dr. akadémikus) \\ MTA SZTAKI \\ Mező Ferenc $(\mathrm{PhD})$ \\ $\mathrm{K}+\mathrm{F}$ Stúdió Kft.
}

...és további két anonim lektor

\begin{abstract}
Absztrakt
A mesterséges intelligencia és a gépi tanulás manapság a digitális technikákat fejlesztők mindennapos feladatai közé tartozik. Szinte naponta hallunk újabb és újabb csodákat, amelyeket robotok végeznek, számítógépi programokról, amelyek korábban megoldhatatlannak számító feladatokat oldanak meg. Vajon van-e, egyáltalán létezik-e elméleti megalapozása, tudjuk-e, lehetséges-e, hogy gépek gondolkozzanak? Izgalmas és mindmáig nyitott a kérdés. A tanulmány az evvel kapcsolatos érvek viták körébe vezeti be az olvasót.
\end{abstract}

Kulcsszavak: mesterséges inteligencia, gépi tanulás

Diszciplinák: matematika, informatika

\begin{abstract}
THOUGHTS ABOUT ARTIFICLAL INTELLIGENCE, MACHINE LEARNING

Artificial intelligence and machine learning are nowadays one of the daily tasks of digital technology developers. Almost daily, we hear more and more miracles performed by robots, and about computer programs that solve previously impossible-looking problems. Is there a theoretical foundation at all, do we know whether it is possible for machines to think? The question is exciting and still open. The study introduces the Readers about the arguments and debates of this issue.
\end{abstract}

Keywords: artificial intelligence, machine learning

Disciplines: matematics, informatics

Gyarmati Péter (2019): Gondolatok a mesterséges intelligencia, gépi tanulás kapcsán. Mesterséges intelligencia - interdiszciplináris folyóirat, I. évf. 2019/1. szám. 31-39.

doi: 10.35406/MI.2019.1.31 
„- Akkor ąt mondom, csinálj lehetetlent!

- Ha megmondod, mi az, a lehetetlen, akkor megcsinálom."

(Gyarmati Péter)

A gépi tanulás, a mesterséges intelligencia mindent elárasztó fontosságának és fejlesztésének korszakát éljük. Hatalmas verseny formálódik a gazdasági életben az eredményekből készíthető eszközök eladásának piaci részesedése terén - tökéletesen igazolva Neumann János egykori kijelentését, mely szerint „a fejlődés ellen nincs gyógymód” (Neuman, 1949): „A fejlődés ellen nincs gyógymód, a tudomány a jövőben inkább a szabályozás és vezérlés, a programozás, az adatfeldolgozás, a kommunikáció, a szervezés és a rendszerek problémáival törődik majd."..

Ahhoz, hogy megértsük ezt a mostani hatalmas érdeklődést érdemes visszatekintenünk a nem is távoli múltba, amely megalapozta mai tudásunkat.

“Tudnak-e a gépek gondolkodni?" merült fel a kérdés (Berkeley, 1949), mivel a számítógépek és társaik olyan tevékenységeket folytatnak, amelyeket az ember az agyával végez. „Egy gép információkat tud feldolgozni, számol, következtet és választ; az információkkal kapcsolatosan racionális múveleteket hajt végre. A gép tehát gondolkodni tud."

A kérdés, illetve az állitás annak idején rendkívül heves, sok esetben szélsőséges, szenvedélyektől túlfütött vitát váltott ki. Ez érthető is, hiszen a kérdés mélyen gyökerező érzelmi és vallási meggyőződéseket is érint. Berkeley-vel szemben a másik szélsőséges álláspontot az egyház képviselte: a gép azért nem tudhat - elvileg - gondolkodni, mert a gondolkodás a lélek tulajdonsága, amely isteni eredetư. Ismét mások azt az álláspontot képviselték, hogy a gépek azért nem képesek gondolkodni, mert a gondolkodás lényegénél fogva az éló anyaghoz, az agyvelőhöz van kötve, a gépek pedig élettelen anyagokból állnak. A kérdés a szakembereket is mélyreható vizsgálódásokra késztette. Ezek során hamarosan kiderült, ahhoz, hogy a kérdésre válaszolni tudjunk, előbb meg kell vizsgálni, mégpedig nemcsak általánosságban, hanem konkréten is, mit jelent tulajdonképpen a „gondolkodás” fogalma. Már a mottóban is felmerült az egzaktság hiánya, ami mindig valamilyen fogalmi területről ered.

A felvetett kérdésre nyilvánvalóan más és más felelet adható, aszerint, hogy milyen társadalom talaján, milyen szempontból, sőt milyen alapképzettségủ szakember igyekszik a választ megfogalmazni. A fiziológusok, feltéve, hogy a kérdéssel egyáltalán foglalkoztak, kissé tartózkodó, óvatos álláspontra jutottak. Stanley Cobb, angol fiziológus a következőket írja: „Az agy a tudat szerve. Az embernél az agyveló hallatlan bonyolultsága az, ami a gondolkodást lehetővé teszi, de az agyveló anatómiájának és fiziológiájának bármilyen mélyreható tanulmányozása sem tudja önmagában megmagyarázni a tudatot. A gondolkodás olyan eseménysorozat, amely az agyvelő egyes részeiben, külső ingerek hatására keletkező, valamint más agyvelőkből érkező információk kölcsönhatásától függ.” Ez 
a meghatározás azért érdekes, mert a gondolkodást reális - tehát anyagi -, a külvilágból érkező ingerekre reakcióként bekövetkező eseménysorozatnak fogja fel. Másrészt azonban éppen az agyvelő logikai szerkezetének bonyolultsága miatt eleve lemondó jellegü.

A. M. Turing angol matematikus már 1936ban kimutatta, hogy minden olyan számot (például valamely matematikai probléma megoldását), amelynek kiszámítására úgynevezett effektiv eljárást (mai szaknyelven szólva: algoritmust) meg tudnak adni, vagyis amelynél a számítási eljárást egyértelmû módon véges számú szabályba lehet foglalni, egy (akkor még csak hipotetikus) automata segítségével ténylegesen ki is lehet számítani. Az ilyen automatát azóta Turing-gépnek nevezik.

A számítógép vonatkozásában (vö.: Gyarmati, 2014) ugyanezt a tételt W. S. McCulloch (fiziológus) és W. Pitts (matematikus) úgy fogalmazta meg, hogy minden olyan eljárást, amelyet teljesen és egyértelmű módon szavakkal ki lehet fejezni, véges számú univerzális kapcsolóelem alkalmas kombinációjával meg is lehet valósítani (McCulloch és Pitts, 1943). Ilyen az élő idegsejt is, állítják.

Ebből viszont Neumann János vonta le azt a fontos következtetést, hogy a mindenkori technikai korlátokon belül a számítógépeket minden olyan múvelet végrehajtására programozni lehet, amelyeket egyértelmű szabályokba lehet foglalni. Mindaz, ami šóbeli formában, szóbeli kérdésekekel kifejezhetố, realizálható is!
A. M. Turing, félretéve minden érzelmi és vallási motívumot, az összes lényeges körülmények számbavétele alapján a következő eredményre jutott: egy gépről akkor lehet azt állítani, hogy ,gondolkodik”, ha egyértelmüen meghatározott kísérleti feltételek között az ember által feltett tetszőleges kérdésre olyan módon tud válaszolni, hogy a kérdező arra a következtetésre jut, hogy azok embertől származnak. Eszerint a gondolkodás definíciója operatív, vagyis a kívülről megfigyelhető viselkedés ekvivalenciája.

\section{Ütköző nézőpontok}

A helyes kérdésfeltevés tehát nem az, hogy tudnak-e a gépek gondolkozni, hanem: milyen múveleteket lehet a gépbe programozni? Milyen fokon képes az adott gép gondolkodni? 1962-ben már sikerült a számítógépekkel logikai problémákat megoldani, matematikai tételeket bizonyítani. Úgy gondolták, hogy az évszázad végére nyugodtan beszélhetünk majd gépi gondolkodásról anélkül, hogy ez bármiféle ellentmondást váltana ki annak ellenére, hogy számosak az ellenvélemények.

Érdemes ezeket áttekinteni, és az alábbiakban meggondolásra ajánljuk:

1. Teológiai ellenvetés. A gondolkodás az emberi lélek funkciója, isten adta, de nem adta azt egyetlen más állatnak, vagy gépnek sem.

Ellenérv ezzel szemben, hogy az Ótestamentum szerint bizonyos állatoknak szintén van lelkük. A lélekhez pusztán meg- 
felelő agyvelővel kell ellátni, amely mutáció kérdése csupán. Aztán itt van még, hogy a mohamedán nézet szerint a nőknek nincs lelkük. Végül a teológiai érvek csak addig élhetnek, amíg a kellő természettudományos tudás nem áll rendelkezésünkre.

2. Struccpolitika. A gondolkodó gépek követkerzményei beláthatatlanok, remébjük ilyen nem fog bekövetkeezni. Az ok az emberi felsöbbrendüség érzete, illetve elvesatésének félelme.

A valóság, hogy az üzleti viszonyok mit sem törődnek bármilyen félelemmel, következménnyel, a fejlődést nem lehet megállítani.

3. Matematikai ellenvetés. A diszkrét állapotú gépek teljesitöképességének korlátai vannak. A Gödel-tétel értelmében bármely elegendöen teljesitó képes logikai rendszerben lehet olyan állitásokat megfogalmazni, amelyeket a rendszeren belül sem megcáfolni, sem bizonyitani nem lehet, kivéve, ha maga a rendszer ellentmondást tartalmaz. (Gödel, 2003). A következmény, hogy a logikai gép válasza hibás lesz, vagy egyáltalán nem válaszol.

Ellenérv, hogy ugyan az emberi eleme mindig képes válaszolni, de vajon mennyi a hibás a válaszok között. Nyilván vannak emberek, akik okosabbak egy adott gépnél, de nyilván vannak, lehetnek olyan gépek, amelyek nála okosabbak és így tovább.
4. Öntudat. Mindaddig, amig egy gép nem tud szonettet, vagy koncertet irni az átérzett gondolatok alapján, hanem tisztán a szimbólumok véletlen elrendezése követkežtében, nem tudunk egyetérteni a\%zal, hogy a gép egyenértékü az agyvelövel, amely nem csak megirja, banem tudja is, hogy megirta. Semmiféle mechanižmus nem tud örömet érezni sikere fölött (mesterséges jelzése olcsó ötlet lenne).

Nyilván vannak különböző szintű korlátok, miként az fennáll az embereknél is. Ha A azt hiszi, hogy „A gondolkodik és B nem”, továbbá, ha $\mathrm{B}$ úgy gondolja, hogy „B gondolkodik és A nem", és ezen vitáznak, akkor csak azt tehetjük fel, hogy mindenki gondolkodik - különben nem lehetne vita. Nem arról van szó, hogy valaki, vagy valami papagáj módjára betanult szöveget ad eló.

5. Képességek biánya. Lehetséges, hogy a ä összes emlitett dolgokat végrehajtó gépet lehet csinálmi, de sohasem tudnak olyat, amely bármely $X$ dolgot végre tudna bajtani. Itt $X$ alatt számos tulajdonságot lehetne emliteni, például a gép legyen kedves, segitókész, szép, barátságos, legyen bumorérzéke, szeresse a tejszines epret, ébresszen szerelmet, stb..

Valóban, gépeink többsége csúnya, a célnak éppen megfelelő kivitelűek, a cél változására reagálni képtelenek, stb.. A miniatürizálás, a nanotechnológia, új anyagok felfedezése lehetőséget adott nagy kapacitású és gyors eszközök fejlesztésére, amelyek már meglehetősen függetlenek külső formájuktól, tehát lehetnek akár szépek is. Elegendő memóriá- 
val rendelkeznek, képesek emlékezni, tanulni, sőt az emberi agynál lényegesen nagyobb kapacitással és sebességgel, mi több pontosan, és megbízhatóan működnek. Láthatjuk, nincsenek határok, pusztán az elért eredmények hiányosak. Van még bőven teendő és evvel együtt lehetőség.

6. Tévedés joga. A gépek, alkotásuk értelmében, tévedhetetlenek. Ha nem igy lenne, nem alkalmaznánk öket. Termész̨etesen nem a meghibásodásról van itt sqó.

Mondatnánk, hogy ez miért baj? Elméletileg egy megoldás változatairól van szó, amelyek értéke különböző lehet, például helyes, kevésbé helyes, kielégítő, valamilyen értelemben rossz, téves. A gépi tanulás képességétôl kezdve megállapíthatjuk, hogy a gép is juthat különböző következtetésekre, miként az ember is ilyen alapon téved, mivel a tanult dolgok más környezetből származnak, mint alkalmazásuk.

7. Lady Lovelace (ót tartjuk az elsö gépi programozónak, a Babbage által kifejlesztett analitikus gépen) felvetése. A gépek nem képesek kezdeményezni, üjat alkotni.

Az ellenvetés legelőször az, hogy a kijelentés kizárólag a rendelkezésére álló, megfigyelt eszközökre vonatkozhatott.

Másodsorban a kérdés: vajon képes-e egy gép meglepetést okozni, azaz olyat tenni, amire nem számítottunk? Nyilvánvalóan, például amikor kiderül, hogy bizonyos feltételezésem, számításom nem volt helyes, mert a gép más eredményt hozott ki, vagy adatbázisából már tudja és közli, hogy elfogyott a színházjegy, de a következő előadásra tud szerezni. Az alapja a mindig aktuális adatbázis - onnan vásárol mindenki belépôt. Tehát a gép tudja, mi nem, a gép szólhat, ha minket érdeklő előadás lesz.

8. Folytonos és diszkéét ellentmondása. Az embert a környezeti hatások folytonosan érintike, és azokra folytonosan reagál. Dis₹łkét módon a reagálásban kiesések lesżnek.

A felvetés óta a neurológiában elért felfedezések az agyvelő diszkrét működését bizonyították. Ahol szükséges az idegek képesek folyamatosan fenntartani a jelzésüket. A gépek is teljesen alkalmasak erre: a vezérlés, a szabályozás diszkrét, a beavatkozás folytonos. Szinte minden kibernetikai rendszer így épül fel.

9. A viselkedés kötetlensége. Lehetséges-e olyan szabálygyüiteményt készíteni, amely az ember, a társadalom számára leirná, hogy bármilyen esetben mit csináljon, hogyan viselkedjen? Ha ez így lenne, akkor az ember is gép lenne, pedig az ember nem lehet gép!

Ellenérv az, hogy a természet, a természeti törvények szabályoznak bennünket teljes egészében, hiszen annak részei vagyunk, mégsem tartjuk magunkat gépeknek. Tudjuk 
viszont, hogy politikusaink, jogászok és mások igénybevételével, erősen „dolgoznak” mindenféle viselkedési szabályok minél teljesebb megfogalmazására. Mindennapos kifejezés a „zéró tolerancia”. Szerencsénkre ez eddig még nem sikerült. Ha csak az erőszak a megfelelő módszer, ahhoz viszont nem kevés csodagéppel kell rendelkezünk: hadi eszközökkel és módszerekkel.

10. Percepció az érzéészerveken túl. Telepátia, gondolatolvasás, elörelátás, akaratátvitel jelenségei még a tudományos felfogásunkat is zavarja, nem hogy gépet készíthessünk ilyen célra.

A percepció más jellegű alkalmazásának egyik fon-tos eleme a hálózatok létrejötte. Nagyon széles skálában ma is kaphatunk kérdéseinkre úgy és olyan választ, amelyek túl vannak érzékszerveink képes-ségén. Már csak a mumusok, kísértetek hiányoznak onnan, talán még ezeket is képes lesz a jövő nem-zedéke előállítani és a világhálón megjeleníteni.

11. Természetes út. A természetnek néhány millió évbe került az emberi intelligencia létrehozása. Vajon az embernek - figyelemmel a felgyorsult tudományos-technikai fejlódésre és eredményeire mennyi idöbe telike a mesterséges intelligencia kiteljesitése egészen az emberi intelligencia szintjêig? Egyáltalán képes lesz-e erre?

A természet a sokféleséggel, a mutációval, és jelentôs környezetváltozásokkal oldotta meg ezt a feladatot. Az élő egyedek szaporodnak, reagálnak a környezetükre és energiaforgalmú működési ciklusuk van. Az élő utánzására legalább e tényezők mesterséges megvalósítása szükséges.

Az egyedek a környezettel és egymással való kapcsolatukból tanulnak és ennek bizonyos részeit a szaporodás során tovább örökítik, valamint a mutáció révén továbbfejlesztik, változtatják. Ami ebből ,tudatos”szándékos célzatú azt nevezhetnénk fejlesztésnek, a többi változás véletlenszerű, ez hozza létre a sokféleséget. Ez a definíció talán nem így pontos, de mindenképen a szaporodás során egymásra épülő környezeti tapasztalatszerzés és a mutáció hozta és hozza létre a törzsfejlődést, melynek kirívó esete az emberi agyvelő. Mai, legjobb tudásunk szerint ez a mi természet adta képességünk, amely a tudás, az intelligencia, az öröklés, a tapasztalatszerzés és a tanulás útján jön létre. Tehát az intelligencia minden egyes emberben az élete során kialakuló folyamat és annak eredménye!

Egy apró kis hiba van azonban ebben az okfejtésben, nevezetesen az öröklés során az agyvelőbe „beépülő” intelligencia rész. Ezt részben magyarázhatjuk az ősök, elődök által szerzett tudás tovább örökítésével, de az első ilyen öröklés, vagy annak képessége már vitatható. Isten, avagy valamilyen teremtő eredetű-e, esetleg a természet játéka, vagy véletlen? Frankensteint és társait az ember teremtette, de mindenkor érezték az „éltető szikra” szükségességét, hozzáadását, amely nélkül lelketlen, holt dolog marad (Mary Shelley „Frankenstein, avagy a modern Prométhe- 
usz" című regényét 19 évesen írta 1816-ban; a mû 1977-es, elsô magyar fordítása Göncz Árpád munkája). A modern irodalom is odáig jut, hogy bárminemû mesterséges intelligencia megvalósítható, de az, az ember nélkül teljességgel értelmetlen marad.

\section{Ember és gép együttmüködése}

A mesterséges intelligencia magas fokának inkább a veszélyét jelzik, amikor is a gépek uralkodóvá válnak és az ember ellen fordulnak. Nyilvánvaló feltételezés ez, hiszen az emberek is állandóan egymás ellen fordulnak. Ez egy kettősség, ami régóta létezik a világunkban, egyrészről bizonyos intelligenciával ellátott eszközöket alkotunk, másrészről törvényekkel, szabályokkal, előírásokkal rábízzuk, azaz ezen eszközök „fennhatósága” alá rendeljük magunkat, valamilyen érdekből kifolyólag. Például, ha az autó motorja jár, akkor a fedélzeti vezérlő számítógép bezárja az ajtókat valamilyen meggondolt védelmünk érdekében. Semmilyen kérésre nem nyitja ki, kizárólag a saját programja előírásai szerint fog cselekedni. Még súlyosabb példa az a terjedő nézet, hogy egyre kevesebb dolgot kell megtanulnunk, mivel - szükség esetén - azt a „gép tudja” és mindig rendelkezésünkre áll. Ez mindaddig megfelelő lehet, ameddig a gép a cselekvő és azt biztosan és mindig helyesen teszi. De valóban így van/lehet ez minden alkalommal? Mert ha mégsem, akkor ki veszi észre és ki változtat rajta? Hiszen a „tudás” a gépben van!

Az ellenvetések ellenére, tehát megállapíthatjuk, hogy a gépek képesek gondolkodni, alkalmasak olyan dolgokra, viselkedésre, melyeket eddig csak az embernek tulajdonítottunk. Igaz, azt is tudjuk, hogy ez nem egy darab komplett gépet jelent, de hát az emberiség sem pusztán egy, hanem teljes társadalom. Azt is megtudtuk, hogy miként az ember nem tévedhetetlen, úgy a gép sem mindig az, kivéve, ha ez a kifejezett szándékunk, miként azt az automatáktól elvárjuk. A gép is mindig az adott környezetben tanul és alkalmazza a tapasztalatait.

Ez az állítás újabb kérdéseket vet fel!

Vajon a gondolkodás valóban mindenféle algo-ritmusok bonyolult együttmúködésének eredménye, vagy itt is létezik egy bizonyos „minőségi ugrás”, amely elválaszt, miként az, az élő és élettelen között az eddigi legjobb ismereteink szerint fennáll?

A kérdésre adandó válasz nyitott, azonban ez nem akadályozhatja az ember világának mindenek feletti fejlődési szándékát, jelen esetben a gépi tanulás, a mesterséges intelligencia, a robotika, az antropomorf eszközök egyre magasabb fokú fejlesztését.

A választ állandóan keressük és rész megoldásaink is vannak. Neumann János (1955) egy tanulmányában ezeket írja: „Az emberi értelem sok olyan tulajdonsággal rendelkezik, amelyeket nem lehetséges automatikusan megközelíteni. A logika ezen típusa, amelyet általában az »intuitív« szóval jelölnek, olyasmi, amiről még rendes leírásunk sincs. A legjobb, legtöbb, amit tehetünk, hogy felosztjuk az összes folyamatot olyanra, amelyeket a gépek és olyanokra, amelyeket az emberek tudnak elvégezni; és azután kitalálunk módszereket, amelyekekel ez a kettö összekapcsolhato". Ma is így gondoljuk, ez 
a fejlődés útja: célunk van, feladat van, a végső megoldás talán nem lehetséges, de nem is szükségszerū.

\section{Remények és eredmények}

A gondolkodó gép eszméjének megszületése azonnal reményeket adott az intelligencia gépesítési álmához. Az első mesterséges intelligencia kongresszus terve 1955-ben merült fel (McCarthy és tsai, 1955) és a rendezvényt 1956-ban Dartmouthban tartották és a LISP első változata már 1958-ban elkészült.

Deklaratív, nem utasítás, jellegú programnyelvek: a LISP, az ERLANG, a PROLOG, az SQL, bizonyos értelemben a HTML-k és társaik. Ezek a mesterséges intelligencia logikájának megfelelőek.

A remény hamar szertefoszlott, kiderült, hogy az emberi okoskodás bármilyen leírása pusztán logika, sőt abban a pillanatban, hogy elkezd gépen működni, algoritmussá válik, tehát nem intelligencia többé.

$\mathrm{Az}$ algoritmus nem intelligencia, hanem állapot szekvencia, vagy rekurzor, amint arról a számítástudományi szakirodalomban bőven olvashatunk. Tipikus példa a perceptron (Gyarmati, 2011), amely pusztán a neuron közelítése mesterséges modellel, s távol van egy bizonyított definíciótól. Kétségbeesésre azonban nincsen semmi ok, mivel az eredmény - a perceptron modell és változatai - számos területen jól alkalmazható eszköz: felismerő- és kereső algoritmusok, stb. területén.

A karakter-, a beszéd-, a nyelv-, a kép felismerés voltak a kezdetek feladatai, amelyek több-kevesebb buktatóval még ma is feladatnak tűnnek. Számos eredményt ért el még a mesterséges intelligenciából fakadó technika, elsősorban a kognitív tudományok területén a szakértői rendszereken át, a statisztikus elméleteken keresztül, amely a robotikával, az adatbányászattal, az automatika kérdéseivel, egészen az ember-gép kapcsolat beszélő és beszéd felismerő csodákig terjed.

Közismert a hasonlat, hogy az intelligencia a forma-homok az öntéskor, a mesterséges intelligencia a mara-dék a homok eltávolítása után. Éppen a mesterséges intelligencia a bizonyíték arra, hogy az intelligencia jelen volt. $\mathrm{Az}$ intelligencia elmaradhatatlan, még ha pillanatai voltak csak.

\section{Zárógondolatok}

Nem szunnyad a „Gondolkozik-e a gép?” kérdés, legfeljebb más, újabb formákban jelenik meg: talán nem is csak egy út - az emberi - létezik az intelligenciához, szólnak a legújabb gondolatok.

Bizonyos vagyok benne, hogy a mesterséges intelligencia területe mindig megújul (vö.: Russel és Norvig, 2003), képes az újabb kihívásoknak eleget tenni és hasznos dolgokra fordítani, az elért eredményeit. Ugyanakkor ne feledjük a veszélyeket, amelyeket éppen az ember képes gépeibe beleépíteni, vagy szándékosan esetleg szándéktalanul is beavatkoz- 
ni legtöbbször valamilyen érdek alapján és minden humán felelősség mellőzésével. A tudósok mellett, most már a technikusnak - a programozónak, a mesterséges intelligencia építőjének és művelójének - is hatalmas a felelőssége.

\section{Irodalom}

Berkeley, E.C. (1949): Giant brains or Machines that think. New York (USA) : John Wiley \& Sons Inc.

Gödel, K. (2003): Néhány tétel a matematika megalapozásáról és ezek következményeirôl. In Csaba Ferenc (szerk.)(2003): $A$ matematika filozófiája a 21. század küszöbén. Osiris Kiadó, Budapest. 61-88.

Gyarmati, P. G. (2011): Some words about networks, ch.17. Perceptron pp. 117-122. TCC COMPUTER STUDIO

Gyarmati, P. G. (2014): A contribution to the Hungarian computer bistory, 1958-1968. Letöltés: 2019.07.20. Web: http://www. freeweb.deltha.hu/gyarmati.dr.hu/compu ter/computer-saga.pdf

McCarthy, J., Minsky, M., Rochester, N. \& Shannon, C. (1955): A Proposal for the Dartmouth Summer Research Project on Artifi-cial Intelligence. Letöltés: 2019.05.10. Web: http://www.formal.stanford.edu/jmc/his tory/dartmouth/dartmouth.html.

McCulloch, W.S. \& Pitts, W. (1943): A logical calculus of the ideas immanent in neurons activity, Bull. Math. Biophys., 1943, vol. 5, pp. 115-133.

Neumann, J. von (1955): The Impact of Recent Development in Science on the Economy and Economics. (speech delivered) published in: Looking Ahead, 1956, No. 4, also in Bródy, A. \& Vámos, T. (eds.) (1995): The Neumann Compendium. London (GB): World Scientific

Neumann J. (1965): A legújabb tudományos fejlõdés hatása a gazdaságra és a közgazdaságtanra. In Neumann János: Válogatott elõadások és tanulmányok. Közgazdasági és Jogi Könyvkiadó, Budapest. 100-102.

Neumann János (1965): Válogatott elöadásoke és tanulmányok. Közgazdasági és Jogi Könyvkiadó, Budapest.

Russell, S. J. \& Norvig, P. (2003): Artificial Intelligence: A Modern Approach (2nd ed.), Upper Saddle River, New Jersey: Prentice Hall.

Turing, A. (1950): Computing Machinery and Intelligence. Mind, LIX (236): 433-460, doi: $10.1093 / \mathrm{mind} /$ LIX.236.433 


\section{PARADIGMAVÁLTÁSOK \\ AZ ELEKTRONIKUS TANULÁSI KÖRNYEZETEK FEJLŐDÉSÉBEN I.}

\section{Szerzők:}

Molnár Balázs $(\mathrm{PhD})$

Debreceni Egyetem

Szerző e-mail címe:

molnarb@ped.unideb.hu

\section{Lektorok:}

Kelemen Lajos (PhD)

Okoskocka Kft.

Ildikó Pšenáková (PhD)

Trnava University in Trnava (Szlovákia)

...és további két anonim lektor

\section{Absztrakt}

A cikksorozat az elektronikus tanulási környezetek technológiai (gépi oldal) és pedagógiai (emberi, felhasználói oldal) paradigmaváltásait mutatja be. Az első rész a fogalmi keretek tisztázása utána az elektromos célgépek (konkrét tanulási feladathoz konkrét céleszközt használunk) korszakát mutatja be és elemzi, amely az e-learning első nagy technológiai paradigmáját jelenti.

Kulcsszavak: oktatás, tanulás, tanítási eszközök, e-learning

Diszciplínák: neveléstudomány, technikatörténet

\section{Abstract \\ PARADIGM SHIFTS \\ IN THE DEV ELOPMENT OF ELECTRONIC LEARNING ENVIRONMENTS I.}

This series of articles presents the technological and pedagogical paradigm shifts of electronic learning environments. In the first part the conceptual framework is clarified then the era of special purpose electric machines (using specific target device for specific learning task) is introduced and analized, which represents the first major technological paradigm of elearning.

Keywords: education, learning, teaching tools, e-learning

Disciplines: Pedagogy, Technical History

Molnár Balázs (2019): Paradigmaváltások az elektronikus tanulási környezetek fejlődésében I. Mesterséges intelligencia - interdiszciplináris folyóirat, I. évf. 2019/1. szám. 41-52.

doi: 10.35406/MI.2019.1.41 


\section{Az elektronikus tanulás értelmezési keretei}

Az e-learning, „elektronikus tanulás” fogalmának tisztázására számos kísérlet történt. Kovács Ilma a definíciós próbálkozásoknak két fő típusát különböztette meg:

„1. Szűkebb értelmezés (visszaszorulóban): teljességében vagy csak részben hálózatra (lokális vagy internet) felvitt képzési rendszerek (beleértve: a tanítást, a tanulást, az információk keresését, a kommunikációt, az interaktivitást).

2. Tágabb értelmezés (terjedőben): bármely elektronikus technológiára/eszközre támaszkodó vagy annak segítségével kivitelezett képzés (a CD-ROM-tól és a számítógéppel támogatott tanulástól a videokonferenciáig, a mûholdak által közvetített képzésekig és a virtuális oktatási hálózatokig)." (Kovács 2007, 79. o.)

Az e-learning szűk értelmezésére eklatáns példa a magyar szakirodalomból Komenczi Bertalan egy korai (2004) megközelítése, amelyben az elektronikus tanulást olyan tanulásszervezési eljárásnak tekintette, ahol online technológiát alkalmazó számítógépek játsszák a főszerepet és távoktatási formában valósul meg a tanulás (1. ábra).

A tág értelmezésből született definíciókra is számtalan példát találhatunk. Az Európai Unió „Az egész életre kiterjedő tanulás európai programjában" is már egy ilyen meghatározás szerepelt (2001), amelyben az elearninget „infokommunikációs technológiával segitett tanulás"-ként írták körül (Making a European Area of Life Long Learning a Reality. Communication from the Commission, 2001,
32. o.). Az IKT gyűjtőfogalmát kikerülő definíciók közül említsük meg Abbas és munkatársainak a meghatározását: „Az e-learning lazán definiálható úgy, mint alkalmazások és folyamatok széles tárbáza, amelyek elektronikus médiát és eszközöket alkalmaznak szakmai tudás átadására” (közli: Nagy 2016, 7), vagy az újabb források közül Bánkeszi és munkatársai megközelítését, amelyben az e-learninget IKT-eszközökre építő szemléletmódként definiálják: „az e-learning vagy elektronikus tanulás olyan oktatási szemlélet, amely magában foglalja a tanulás és az. oktatás folyamatának. IKT es₹közökekel támogatott, formailag, tartalmilag és módszertanilag is újszerú formáit." (Bánkeszi és tsai, 2017, 545. o.).

1. ábra: Az e-learning Komenczi Bertalan-féle értelmezése (Forrás: Komenczi, 2004 alapján)

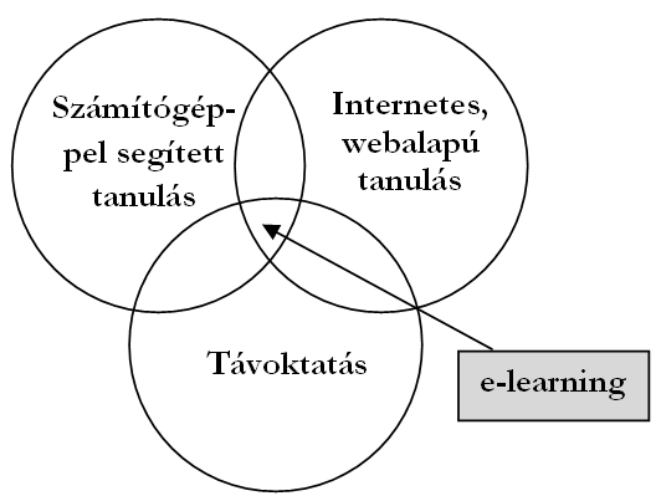

A tág értelmezésben a központi elem tehát az, hogy elektronikus eszközöket használunk a (bármilyen formában megvalósuló) tanulás folyamatában. Az elektronikus eszköz játszhat alapvetô szerepet is a folyamatban (Kovács Ilma erre az elektronikus technológiá- 
ra/eszközre támaszkodó kifejezést használta), de betölthet kiegészítő, segítő pozíciót is (Kovács meghatározásával élve: elektronikus technológia/ eszköz. segitségével kivitelezett képrés). A használati mélység két szintjét jól mutatja a pedagógia szakirodalomban gyakran használt IKT alapú oktatás és az IKT-vel támogatott oktatás kettős fogalomköre is (Lengyelné Molnár és tsai, 2013).

Az e-learning szúk értelmezésében valamilyen online eszköz játszik tehát szerepet, a tág definíciókban valamilyen IKT, vagy még tovább tágítva a fogalmat, valamilyen elektronikus eszköz. Az e-learninget azonban még szélesebb perspektívában is értelmezhetjük, mivel már a digitális korszak előtt is léteztek elektromos technológián alapuló információs és kommunikációs eszközök, melyek felhasználhatók voltak a pedagógiai folyamatokban.

Kovács Ilma is utal erre a lehetőségre: „A telefon már 1876-tól (Bell) igazi forradalmat váltott ki, hiszen egyidejüleg küzdötte le a földrajzi és idöbeli korlátokat: az ember már maga választhatta meg, bogy kivel akar beszélgetni, mikor és miröl akar valakit informálni, kivel akar kommunikálni." (Kovács 2007, 51. o.), de más kutatók is az elearning eszközrendszeréhez tartozónak vallják ezeket a korai infokommunikációs berendezéseket. Jól ismert Pownell és Bailey szakaszolása (2001), amelyben a szerzók az elearning eszközök négy generációját, „hullámát" különböztették meg. Ebben a rendszerben az első nemzedék ezeket az eszközöket fedi le: az első hullám már 1970 előtt elkezdődött és a hangalapú technikák (lemezjátszók, magnókazetták) jelentették - eleinte - a fő vázát. A második hullám a hetvenes években indult a személyi számítógépek megjelenésével. A harmadik hullám 1990. körül kezdődött az internet elterjedésével és a világháló megjelenésével. Végül a negyedik hullám az új évezred elején vette kezdetét a hordozható eszközök (pl. a laptopok és a mobiltelefonok) elterjedésével (közli: Seres, 2013).

Ha a fenti megközelítésmódokat összegezzük, akkor azt látjuk, hogy az egyes definíciókban szereplő e-learning eszközök egy táguló koncentrikus kört határoznak meg (2. ábra). Minél „,beljebb” vagyunk, annál szúkebb a definíció, minél külsőbb kört, nagyobb halmazt választunk alapnak, annál tágabb értelmezést adunk (technológiai szinten) az elearningnek.

2. ábra: Az e-learning definiciókban szereplö eszkeözök rendszere (forrás: a Szerzö)

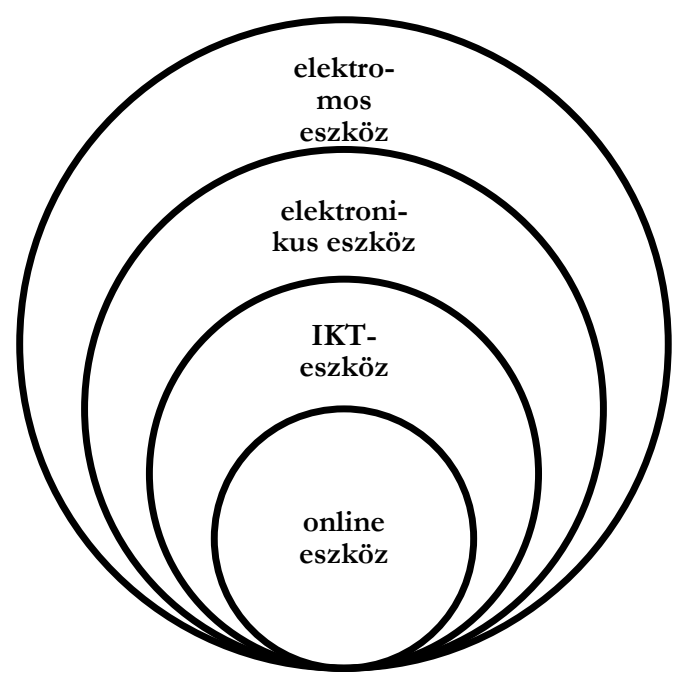


Amennyiben a paradigmaváltások elemzése során az e-learning minél szélesebb spektrumát szeretnénk lefedni, úgy a legmegengedőbb definíciókból érdemes kiindulni. Ezek alapján a továbbiakban az e-learningre olyan tanulási tevékenységként tekintünk, amelyben felhasználunk valamilyen elektromos (napjainkban természetesen már inkább elektronikus) es₹közt, hogy támogassuk (de nem feltétlenül erre alapozzuk!) a pedagógiai folyamatot.

Az „eszköz” megléte, annak változásai tehát, a definícióból kiindulva, elengedhetetlen a fô paradigmák meghatározásához. Az egyes e-learning generációk meghatározása azonban más szempontokból is történhet (bővebben lásd Berecz 2017). A pedagógiai folyamatokban mindig szerepet játszik az ember is, így a technikán túl az ember-gép interakciók emberi oldalára is figyelnünk kell. Ennek megfelelően cikksorozatunkban erre a két fő komponensre (ember és gép) fogunk koncentrálni, ezek alapján tárgyaljuk a paradigmaváltásokat. Egyrészt technológiai szempontból („gépi oldal”) adjuk meg a fő paradigmatikus változásokat, másrészt pedagógiai szempontból („emberi oldal”). Ez a két idővonal, mint látni fogjuk, egymásba fonódik, alakítja egymást, mégsem vannak mindig szinkronban egymással.

Az e-learning generációkat tárgyaló munkák az egyes generációk kronológiai besorolásához gyakran kezdő és záródátumokat adnak meg. Jelen tanulmányunkban azonban csak a kezdő időpontok (évtizedek) megadását tartjuk indokoltnak, ugyanis az egyes generációk sokáig egymás mellett élhetnek, ha- sonlóan például a fűnyíráshoz: ha szükséges, elővesszük a kaszát vagy a sarlót, de bekapcsolhatjuk a kézi, motoros fünyírót is, míg a szomszédban már vígan dolgozik egy robotfünyíró. Ennek megfelelően megtörténhetett, hogy 1998-ban, idegennyelv-órán, még magnóról hallgatták a tanulók az anyanyelvi beszédet (első generációs e-learning eszköz), informatika órán offline tanulták a teknőcgrafikát (második generációs eszköz), ugyanakkor voltak, akik otthon már online gyüjtöttek anyagot a tanulmányaikhoz (harmadik generációs eszköz). Természetesen az egyes eszközök arányai fokozatosan eltolódnak, a korábbi generációk lassan ,kikopnak” a napi gyakorlatból, míg az újabbak egyre nagyobb teret nyernek. Ez azonban nem egyik napról a másikra történik.

Cikksorozatunk első részében a technológiai paradigmák, paradigmaváltások bemutatását kezdjük el.

\section{Első generációs eszközök (elektromos céleszközök kora, 1890-es évektől)}

Az előző rész gondolatmenetéből kiindulva viszonylag egyszerűnek tűnik az e-learning első paradigmájának meghatározása: a tanítási-tanulási folyamatokban elektromos, analóg eszközök jelennek meg, vannak jelen. Ezt a paradigmatikus váltást azonban célszerű szűkítenünk, kizárva azokat az eszközöket, amelyek magát az elektromosság jelenségét hivatottak bemutatni, ebben az esetben az elektromosság ugyanis önmagáért jelenik meg a tanítási-tanulási folyamatokban, pusztán tartalmi, nem pedig folyamattényezőként (az 
elektromosság, tananyagként való megjelenésére remek példa Purgine János 1746-ban megjelent verses tankönyve a „De vi electrica carmen didacticum"). Olyan elektromos eszközökre koncentrálunk tehát a továbbiakban, amelyek egyéb tanulási tartalmak közvetítését támogatták.

Az 1820-as évektől kezdve egyre többen kísérleteztek az elektromosságban rejlő információközvetítő lehetőségekkel. Az első gyakorlatban is jól használható eszköz a Morse-féle vezetékes távíró volt, amelyet 1838ban mutattak be. A XIX. század közepén már szép számmal találhatunk postai úton mûködő távoktatási kurzusokat, azonban a telegráf nem forradalmasította az oktatás ezen ágát - a betűnként vagy szavanként fizetett díjak egyszerūen túl magasak voltak (Mackay 2013). Az osztálytermi oktatásban sem lehetett igazából szerepet találni neki.

(1.) A század második felében azonban már megjelentek azok a technikák is, amelyek a jelenléti oktatás igényeihez igazodva képesek voltak különböző típusú információkat hatékonyan tárolni és előhívni. Tetszőleges hangok elektromos technikával történő rögzítésére és előhívására alkalmas első eszközt, a fonográfot, Thomas Alva Edison (18471931) 1878-ban szabadalmaztatta és abban az évben már kiskereskedelmi forgalomba is került az első változata. Mint látni fogjuk a korszak egyéb találmányainál is, a pedagógiai célú felhasználás lehetőségeit is gyorsan meglátták az oktatással, neveléssel foglalkozó szakemberek. A fonográf oktatási célú felhasználásáról 1891-ben született az első ismert fel- jegyzés (Mark - Gary, 2007). Az előre rögzített hangfelvételek visszaadására - bár otthoni vagy iskolai felvételek készítésre nem volt alkalmas - jóval praktikusabb eszköz, a gramofon is rövidesen megjelent, amely Emile Berliner (1851-1929) invenciója volt. Berliner 1894-ben kezdte el a gramofon tömeggyártását, illetve a lemezkiadást az Egyesült Államokban. A következő években, évtizedekben mind maga a készülék, mind a hanglemezek komoly fejlődésen mentek át (pl. 1904-ben vezették be a mindkét oldalon lejátszható lemezeket, megduplázva a tárolt hang mennyiségét), amely eredményeképp a gramofonból fokozatosan alakult ki a harmincas-negyvenes évekre a mai értelemben vett lemezjátszó.

Valdemar Poulsen (1869-1942) dán mérnök 1898-ban készítette el az első, gyakorlatban is használható mágneses hangrögzítő berendezést, majd Fritz Pfleumer (1881-1945) német-osztrák mérnök 1928-ban szabadalmaztatta a mágnesszalagot. Ez alapján debütálhatott 1935-ben az első AEG által gyártott, K1 típusjelű magnó. A magnetofontechnológia Németországon kívüli elterjedése azonban csak a második világháború után kezdődött el. A fejlesztéseknek és a csökkenő áraknak köszönhetően az oktatási célú alkalmazása az ötvenes évekre mind gyakoribbá vált. A hordozhatóságot tovább növelte a kompaktkazetták megjelenése a hatvanas évek közepén, amely az első (Sony gyártmányú) walkman 1979-es megjelenéséhez vezetett (Kimizuka, 2012). A rögzített hang ezzel vált a formálódó m-learning (mobil-tanulás) vezérhajójává. Az audio eszközök következő nagy generációja a CD és annak hordozható 
lejátszója (az első, ún. „Discman”-t szintén a Sony kezdte el gyártani 1984-ben) már a digitális eszközök közé tartozott, az e-learning következő nemzedékéhez.

(2.) Az oktatásban használt vizuális eszközök (pl. illusztrált tankönyvek) komoly múltra tekintenek vissza. Témánk szempontjából a különböző vetítőeljárások bírnak nagy jelentôséggel. Ezek kezdetben teljesen mentesek voltak az elektromosságtól, az általában üvegre festett képeket mécses, gyertya, később olajégő, borszeszégő vagy petróleumlámpa fénye vetítette ki. Az első vetítőgép a laterna magica volt, amely prototípusát az itáliai humanista mûvész, Leone Battista Alberti (1404-1472) építette 1437-ben. Ez a találmány azonban többször is feledésbe merült és „újra fel kellett találni”, míg az 1600-as évektől kezdve már megszilárdult a jelenléte. A XVIII. századra nem csak a pedagógia ismert szemléltetőeszközévé nőtte ki magát, de megszülettek az elsô mozgó laternaképek is (Nekes, 2009). A XIX. században már, „a film” megszületése előtt, számos mozgóképes megoldással találkozhatunk, ilyen volt például a fenakisztoszkóp, zoetróp, praxinoszkóp vagy az egyszerū pörgetős füzet, a kineográf is.

Akár az állóképek, akár a mozgóképek megjelenítése, kivetítése lehetséges volt tehát elektromos technika nélkül is, ám az elektromosság forradalmasította ezeket a korai eszközöket. Elsősorban két olyan találmányt kell megemlítenünk ezzel kapcsolatban a XIX. században, amely minőségi ugrást jelentett a vizuális eszközök világában. Az egyik a vetítőgépek fényerejét megsokszorozó izzólámpa volt, a másik a filmszalagok továbbításához szükséges egyenletes forgómozgást biztosító elektromotor, amely nem sokára a korai mechanikus megoldások sokkal hatékonyabb alternatíváját jelentette (a hangosfilm megjelenésétől kezdve különösen fontossá vált az állandó sebesség). Természetesen egyéb elektromossággal kapcsolatos találmányokat (pl. az „áram” előállításához, tárolásához, a továbbítás folyamatához kapcsolódóan) is megemlíthetnénk, azonban közvetlen hatásában mégis talán ez a két eszköz volt meghatározó.

$\mathrm{Az}$ első ismert elektromos árammal működtetett izzót Sir Humphrey Davy (17781829) alkotta meg 1802-ben, amely elindította a kísérletező kedvet és a következő évtizedekben sorra születtek a kapcsolódó találmányok, fejlesztések. A kereskedelmi forgalomra alkalmas, kellő hatékonyságú izzólámpát azonban csak 1879-ben szabadalmaztatta Edison. Ezután azonban az elektromos világítás rohamtempójú elterjedése következett.

Az elektromotor, villanymotor (Jedlik Ányos kifejezésével élve: villamdelejes forgony) megalkotása még régebbre nyúlik, hiszen az első elektrosztatikus motorokat Andrew Gordon (1712-1751) és Benjamin Franklin (1706-1790) építették a XVIII. század közepén. Az egyen- és váltóáramú motorok építése az 1820-as évektől kezdve gyorsult fel (pl. 1821-ben Faraday építette meg az első egypólusú villanymotort), majd az izzólámpához hasonlóan számos feltaláló egymásra épülő fejlesztései révén váltak egyre hatékonyabbá és megbízhatóbbakká. Thomas 
Davenport (1802-1851) 1837-ben szabadalmaztatott egyenáramú elektromotorja 600 fordulatot tudott percenként elérni és korlátozottan bár, de a gyakorlatban is felhasználták (szerszámgép, nyomdagép működtetésére). Az első nagyteljesítményű, modern technikai megoldásokat használó villanymotorok az 1880-as, 90-es években kerültek kereskedelmi forgalomba. A századforduló környékére így a vetített (mozgó)kép mindkét elektromos összetevője, a nagy fényerôt biztosító izzólámpa és a megbízható elektromotor is készen állt arra, hogy integráns (alkat)részeivé váljanak a vizuális, majd audiovizuális taneszközök XX. századi forradalmának.

A vetítéssel összekapcsolt, mai értelemben vett film Auguste (1862-1954) és Louis Lumiere (1864-1948) munkásságához kapcsolódik, akik 1895. február 13-án szabadalmaztatták a technológiát. Még abban az évben, az első nyilvános (és fizetôs) vetítésen tíz rövidfilmet vetítettek le az érdeklődőknek. A filmben rejlő pedagógiai lehetőségek annyira nyilvánvalóak voltak, hogy lényegében azonnal elkezdődtek az ezzel kapcsolatos munkálatok. Az első magyar ismeretterjesztőoktatási célzatú filmet, alig hat évvel később, 1901-ben készítették Pekár Gyula „A táncz” című előadásához kapcsolódóan (Szabó Sóki, 2009). A gyors fejlődést jól illusztrálja, a George Klein által összeállított 1910-es amerikai oktatófilmlista is, a Catalogue of Educational Motion Pictures, amely 30 témakörben, 1065 címet tartalmazott (Saettler, 2004). A fejlődéssel a magyar pedagógia is igyekezett lépést tartani: 1913-ban, Ágotai Béla (1864-1956) vezetésével, Budapesten meg- alakult a Pedagógiai Filmgyár, amely, szervezeti átalakulásokkal ugyan, de 1940-ig múködött (Bíró 2011).

A film a későbbiekben hangossá (általában a Warner Brothers A dzsesszénekes címú 1927es filmjétől datálják), majd színessé vált (ha a korai színezős eljárásoktól eltekintünk, akkor a harmincas években születtek az első sikeres próbálkozások). Ezek az új technikák több csatornássá (kép-hang) és intenzívebb élménnyé tették a befogadást.

Nem csak a filmek megtekintése, de a filmek készítése is lehet pedagógiai célzatú tevékenység, ehhez pedig a házi filmfelvevő kamerák megjelenése volt szükséges. Az első valóban jól használható otthoni kamera az Aeroszkóp volt, amelyet 1909-ben szabadalmaztatott Kazimierz Prószyński (1875-1945) lengyel feltaláló - igaz, ez még sűrített levegővel működött. Az elektromos házi kamerák használatát elsősorban az akkumulátor problémája hátráltatta, de az 1960-as évekre, a Super 8 filmformátum elterjedésének idejére már sikerült ezt megoldani.

Oktatási szempontokból kiemelkedő jelentőségú állókép vetítési technológiának számított az „írásvetítő”, amely a nyolcvanas, kilencvenes években gyakori vendég volt a magyar iskolai osztálytermekben is. Az állóképvetítők képesek lehetnek átlátszó vagy nem átlátszó objektumok kivetítésére is (episzkóp, epidiaszkóp). Habár az első típusokat már a XIX. században kifejlesztették, a valódi áttörésre a XX. század közepéig kellett várni.

Az írásvetítő, a mai prezentációs eszközök analóg elődje, eleinte festett üveglapokat, később átlátszó fóliát használt. Már a XIX. szá- 
zad második felében voltak próbálkozások, de csak az 1930-as években jelentek meg, terjedtek el az átlátszó fólia kialakításához szükséges műanyagok, majd az ötvenes években az olcsó műanyag lencsék - ezek forradalmasították és tették tömegesen elérhetôvé a technológiát. Az első modern írásvetítôt 1962-ben mutatta be egy fiatal fizikus, Roger Appeldorn (1935-) vezette team az USA-ban, amely hamarosan az oktatásban is elterjedt.

(3.) Az e-learning első generációjában megjelentek tehát az auditív anyagok rögzítésére és lejátszására alkalmas eszközök (fonográf, gramofon, lemezjátszó, magnetofon stb.). Az elektromosság forradalmasította a vizuális/audiovizuális szemléltetést elősegítő vetítőeszközöket (diavetítô, írásvetítő, filmvetítő stb.), mozgóképkészítő eszközöket (filmfelvevő kamera). A harmadik nagy terület, amely alapjaiban változtatta meg és tette „elektromossá" a tanulást, a híradástechnika volt, amely olyan eszközöket adott a pedagógia számára, melyekkel a tanulási tartalmakat nagy távolságba, nagy pontossággal és rendkívül gyorsan lehet eljuttatni.

A hang eljuttatására szolgáló első eszköz a már korábban is említett telefon (Meucci, 1874; Bell, 1876) volt, amely nemcsak az oktatásszervezést könnyítette meg, de az írott/nyomtatott távoktatási anyagokat is kiegészíthette (1910-ben már közel hatmillió telefon működött az Egyesült Államokban!).

Az első olyan elektromos eszköz, amellyel tömegeknek lehetett egyidőben oktatási tartalmakat közvetíteni, a rádió volt. A technológia az 1890-es években született meg (pl.
Tesla, Marconi, Popov munkássága nyomán) és az 1910-es évekre vált nagykorúvá (pl. Meissner-oszcillátor, 1913). Az I. világháborút követően az amerikai egyetemek gyors fejlesztésekbe kezdtek és sorra hozták létre saját rádióállomásaikat. A rádióadásokon alapuló tanítás-tanulás az 1920-as évek közepére már nagy népszerűségnek örvendett az USAban, rövidesen pedig Európában is megjelent. Azokban az országokban, ahol az ismeretközvetítésnek komoly fizikai akadályokat (pl. nagy távolságokat) kellett legyőzni (pl. Ausztrália, Új-Zéland), a rádión keresztül megvalósított, később rádió-adóvevőkkel is megtámogatott oktatási programok különös jelentőségre tettek szert, már a harmincas évektől kezdődően (Johnson 2003).

A kezdetektől fogva nyilvánvaló volt, hogy az elektromágneses hullámok nem csak hang, de képközvetítésre is alkalmasak. Az ezzel kapcsolatos fejlesztések már a XIX. század második felében megindultak (például Nipkow-tárcsa, katódsugárcső). A szakembereknek nagyobb kihívásokat kellett legyőzniük, mint a rádió esetében, ezért az áttörésre az 1920-as évekig várni kellett, amikor is megszülettek az első működőképes készülékek, például John Baird (1888-1946) vagy Mihály Dénes (1894-1953) munkásságának köszönhetően. A technológia gyorsütemű fejlődésnek indult, így 1936-ban a berlini olimpiáról már nem csak rádióközvetítést hallgathattak, de a német posta jóvoltából tévéközvetítéseket is nézhettek az érdeklődők - igaz ezeket még külön szalonokban, „nézőszobákban" tehették meg, nem pedig az ottho- 
nukban. Rövidesen elkezdődhetett a televíziók sorozatgyártása is.

A második világháború hatására megtorpant a televízió terjedése, ám utána rendkívül gyors fejlődésnek indult a televíziózás és hihetetlenül népszerű médiummá vált. $\mathrm{Az}$ USA-ban már 1955-ben megtörtént az első színes közvetítés is, de Európában csak az 1970-es évekre kapott erőre az újítás. A televíziónak köszönhetôen a mozgókép, könynyen elérhetô változatos tartalmakkal, az iskolai tantermek és az otthonok mindennapos élményévé válhatott. Az ebben rejlő pedagógiai potenciál teljesen egyértelmû volt, így a televízió elterjedését követő években a nevelési-oktatási programok, tartalmak gyors felfutását láthatjuk. 1947-48-tól kezdődően több országban (pl. USA, Anglia, Franciaország) megkezdődik az oktatási tartalmak sugárzása (Nagy 1968), az ötvenes évek elejétől kezdve pedig mind több tudományos kutatással is találkozhatunk, amelyek a televízió által közvetített oktatófilmek, műsorok különböző aspektusait vizsgálták (Seels és tsai., 2008). Magyarországon 1957-ben indult el a hivatalos mûsoradás, és hat évvel később, 1963-ban már meg is alakult a Magyar Televízió egyik szervezeti egységeként az Iskolatelevízió, amely a következő év elején kezdte el az oktatótartalmak sugárzását (Nagy 1968). A szerkesztőség a nyolcvanas évek közepén történő szerkezeti átalakulása után egészen 1994-ig működött és készített ismeretterjesztő műsorokat.

A televíziós oktatóműsorok komoly pedagógiai lehetőségeket rejtettek magukban: többcsatornásak (látás, hallás) voltak, a fel- használók számára költséghatékonyak (a készülékek ára, az előfizetési díjak egyre megfizethetőbbekké váltak), és nem csak változatos, de szórakoztató (edutainment), motiváló tartalmakkal operálhattak. A problémát egyrészt az idő jelentette, a felhasználóknak, a nézőknek a műsorok időpontjához kellett igazodniuk, másrészt a kötött műsorszerkezet - a műsorrendet központilag határozták meg, a helyi vagy egyéni igények nem nyerhettek teret. Ezekre a kihívásokra adott választ a képmagnó (videomagnetofon, „videó”): „Ar elsö videókazettás lejátşók azért születtek meg, mert igény volt egy olyan eszkö̈rre, amely - akár a magnetofon, a rádio esetében - alkalmas a televiziókban sugárzott müsorok felvételére, s eqáltal felszabadítja a nézốt attól a kényszertöl, hogy idôbeosztását a tévé müsorától tegye függövé." (Jancsó, 1985).

Az első mágnesszalagos (mozgó)képrögzítő eszközök az ötvenes években kerültek kereskedelmi forgalomban, de az igazi elterjedésük csak a hetvenes években kezdődött, amikor már az aránylag megfizethető árú, kazettás megoldások (elsősorban a Betamax és a VHS kazettarendszerek terjedtek el) jelentek meg a boltok polcain. A hetvenes évek második felétől elindult a mûsoros videokazetták és a videokölcsönzés üzletága is. A képmagnó rendkívül népszerű eszközzé vált, amelyet csak az ezredforduló után sikerült kiszorítania az otthonokból és az iskolákból az optikai lemezes (DVD-lejátszók; CD-re írt, számítógépen lejátszott filmek stb.) eszközöknek.

A képmagnó szintén felbecsülhetetlen értékű eszköznek bizonyult a pedagógiában, és nem csak az audiovizuális tartalmak elérését tette rugalmassá a tanítási-tanulási folyama- 
tokban, de a videokamerák a különböző megfigyelések rögzítésének és az önreflexió kiváló eszközeit jelentették. Ennek köszönhetően a pedagógusképzésben is már nagyon hamar teret nyert a használata, például a tanítási és mikrotanítási gyakorlatok rögzítésében, illetve későbbi elemzésében. Nagy Andor (1932-), a magyar médiapedagógia egyik úttörője, már 1968-ban így írt a „közeledő” technikáról: „A képmagnetofon segitségével lehet majd venni, illetve rögzíteni a jelöltek óráit és a vetitéskor maguk is meggyózódhetnek hibáikeról, illetve láthatják és hallhatják majd, hogy hogyan valósultak meg elképzeléseik." (Nagy 1968, 53. o.).

(4.) A XX. században megjelent még egy új eszköztípus, amely nem csak a hagyományos tanítási-tanulási folyamatok kiegészitését vagy a résztvevők közötti közvetítést vállalta fel, hanem benne rejlett a tanári oldal radikális újraértelmezése is - ez az ún. oktatógép volt.

Az oktatógépek, amelyek gyakran nem is elektromos, hanem mechanikus megoldásokkal operáltak, története az 1920-as évekre nyúlik vissza, amikor már több próbálkozás is történt a tanítás automatizálására (az ettől is korábbi eszközöknél általában valamely elem hiányzott a folyamatból, például nem adott visszajelzést a diákoknak a válaszaik helyességéról). 1920-ban a lengyel Stanislaw Trebicki szabadalmi kérelmet nyújtott be egy „a tanulást külső segítség nélkül megkönnyítő berendezésre", 1923-26 között pedig Sydney Pressey (1888-1979), az Ohio-i Egyetem pszichológia professzora fejlesztett feleletválasztáson alapuló gépeket (Okon 1973). Ezek az első próbálkozások azonban még eléggé visszhangtalanok maradtok, a korszak nem volt nyitott a tanulás ilyen fokú gépesítésére. Az oktatógépekben, illetve a gépi oktatásban rejlő lehetőségekre B. F. Skinner (1904-1990) ötvenes évekbeli eszközei hívták fel a figyelmet (Johnstone, 2003). Ez azonban már egybeesett a számítógépes technológia megjelenésével, így az oktatógépek (amelyek célgépek voltak) karrierje hamar le is áldozott, átvették a helyüket az alapvetően univerzális felhasználásra tervezett számítógépek - ez pedig átvezet bennünket az e-learning eszközök második generációjához.

Az oktató célgépek közül, amelyek jellemzően már elektromos technológiát is alkalmaztak, a szimulátorok futottak be nagyobb karriert. Az első, kereskedelmi forgalomba kerülő repülőgép-szimulátort Edwin Albert Link (1904-1981) építette 1929-ben. A későbbiekben a szimulátorok is számítógépalapú berendezésekké váltak, de a valósághű élményvilág megôrzése miatt még napjainkban is sok megőrizte célgép-jellegét (pl. valódinak tűnő, mozgó pilótafülkébe kell beülni a kezeléshez).

Az elektromos berendezések az oktatásban, elsősorban a fonográf és az izzólámpa fényerejét felhasználó vetítőeszközöknek köszönhetően, az 1890-es években kezdtek megjelenni és a fejlődésük az 1980-as évekig töretlennek mondható. Ezek az eszközök alapvetően céleszközök voltak, valamilyen konkrét feladat mind magasabb színvonalú és mind olcsóbb elvégzésére voltak alkalmasak (pl. hangfelvételre- és visszajátszásra, filmnézésre stb.). A paradigmaváltás a számítógép 
megjelenéséhez volt köthető, amely, megfelelő perifériákkal ellátva, univerzális, illetve az univerzalitás lehetőségét magában rejtő technológia. Ez az eszköz, a computer, indította el az e-learning második generációját, amely következő cikkünk témáját adja.

\section{Irodalom}

Berecz, A. (2017). Javaslat az e-learning modellek osztályozására. Journal of Applied Multimedia, (12. évf.), 4. sz., 55-75. Letöltés: 2019.06.01. Web: http://www.jam paper.eu/Jampaper_E-ARC/No.4_XII_ 2017/Entries/2018/6/11_Day_of_longb oarding_files/JAMPAPER170401h.pdf

Berecz, A., és Seres, Gy. (2013). „Mobilizing e-learning". Journal of Applied Multimedia, (8 évf.), 2. sz., 53-62. Letöltés: 2019. 06. 11. Web: http://www.jampaper.eu/Jam paper_HUN/Friss_files/JAMPAPER130 202e.pdf

Bánkeszi, K., és Szepesi, J. (2017). Az elektronikus tanulás, avagy gondolatok az elearning világáról. Könyvtári figyelō, (63. évf.), 4. sz., 541-548.

Bíró, F. (2011). Szalagos diafilmvetítés a XX. század első felében. Könyv és nevelés (13. évf.) 4. sz. Letöltés: 2019.05.28. Web: http://olvasas.opkm.hu/portal/felso_me nusor/konyv_es_neveles/szalagos_diafil mvetites_a_xx_szazad_elso_feleben

Jancsó, G. (1985): Gyártók, piacok, jogok Kitekintés a képmagnózás világára. Filmvilág, (28. évf.), 3. sz., 21-26.

Johnson, J. L. (2003). Distance Education: The Complete Guide to Design, Delivery, and
Improvement. Teachers College Press, New York.

Johnstone, B. (2003). Never Mind the Laptops: Kids, Computers, and the Transformation of Learning. iUniverse, New York.

Kárpáti, A., és Molnár, É. (2004). Képességfejlesztés az informatika eszközeivel. $M a$ gyar Pedagógia, (104. évf.), 3. sz., 293-317.

Kimizuka, M. (2012). Historical Development of Magnetic Recording and Tape. Letöltés: 2019. 05. 21. Web: http://sts.kahaku.go.jp/diversity/docume nt/system/pdf/073_e.pdf

Komenczi, B. (2004): Didaktika elektro-magna? Az e-learning virtuális valóságai. Új Pedagógiai Sz̨emle, (54. évf.), 11. sz., 31-49.

Kovács I. (2007). Az elektronikus tanulásról. Holnap Kiadó, Budapest.

Lengyelné Molnár, T., Kis-Tóth, L., Antal, P., és Racsko R. (2013). IKT innováció. Eszterházy Károly Főiskola, Eger.

Mackay, J (2013). Online schools. Lucent Books, United Kingdom.

Making a European Area of Life Long Lerning a Reality. Communication from the Commission, Brussels, 21. 11. 01. COM (2001) 678 final. Letöltés: 2019.05.12. Web: https://eurlex.europa.eu/LexUriServ/Le xUriServ.do?uri=COM:2001:0678:FIN:E $\mathrm{N}: \mathrm{PDF}$

Mark, M. L., és Gary, C. L. (2007): A history of American Music Education. MD: Rowman \& Littlefield Education, Lanham.

Nagy, A. (1968). A televízió oktató műsorának didaktikai és nevelési funkciói. $A z E g$ ri Tanárképzó Föiskola tudományos közlemé- 
nyei $=$ Acta Academiae Paedagogicae Agriensis, 6. kötet, 31-58.

Nagy, V. (2016): E-learning ABC. Vezetéstudomány, (48. évf.), 12. sz., 6-15. DOI: 10.14267/VEZTUD.2016.12.01

Nekes, W. (2009). Az optikai médiumok glosszáriuma. In Kékesi Z., Peternák M. (Ed.). Pillanatgépek. Budapest: Műcsarnok. pp. 193-204.

Okon, W. (1973). Felsőoktatási didaktika. Felsőoktatási Pedagógiai Kutatóközpont, Budapest.

Seels, B., Berry. L., Fullerton, K., és Horn, L.C. (2008): Research on learning from television. In: Jonassen, D. (Ed.). Handbook of Research on Educational Communications and Technology. Mahwah, NJ, US: Lawrence Erlbaum Associates Publishers. pp. 249-334.

Seattler, P. (2004). The evolution of American educational technology. Greenwich: Information Age Publishing Inc.

Szabó Sóki, L. (2009): A magyar oktatófilm története a kezdetektől 1931-ig. Magyar Pedagógia, (109. évf.), 1. sz., 29-47. 


\title{
SZÁMÍTÓGÉPES DOHÁNYZÁS-PREVENCIÓ AZ ISKOLÁBAN
}

Szerzők:

Csibi Mónika (PhD)

Marosvásárhelyi Orvosi

és Gyógyszerészeti Egyetem

(Románia)

Csibi Sándor (PhD)

Marosvásárhelyi Orvosi

és Gyógyszerészeti Egyetem

(Románia)

Első szerző e-mail címe:

csibi.sandor@umftgm.ro

\section{Lektorok:}

Kelemen Lajos (PhD)

Okoskocka Kft.
Szabóné Balogh Ágota (PhD)

Gál Ferenc Főiskola

\begin{abstract}
Absztrakt
Prospektív kutatásunk egy számítógépes prevenciós beavatkozás elvégzése után jelentkező dohányzási motiváció-átstrukturálódásokat elemzi. A résztvevőinket 16 marosvásárhelyi középiskola tanulóiból választottuk ki, összesen 1369, 15-16 év közötti serdülőt. Eredményeink szerint a dohányzó serdülők magasabb dohányzás melletti motiváció értékeket és kevesebb dohányzás elleni érveket mutatnak a nem dohányzó serdülőkkel szemben. A programban való részvétel eredményeként a dohányzó serdülők cigarettafogyasztása jelentősen csökken, így arra következtetünk, hogy a számítógépes prevenciós program sikeresen alkalmazható serdülő populáción.
\end{abstract}

Kulcsszavak: dohányzás, prevenció, számítástechnika

Diszciplinák: pszichológia, informatika

\section{Abstract \\ COMPUTER TOBACCO PREVENTION AT SCHOOL}

Our prospective study analyzes the restructuring of smoking motivation after completing a computer-based prevention intervention. Our participants were selected from 16 high school students in Târgu Mureş, a total of 1369 adolescents aged 15-16. Our results show that smoking adolescents show higher motivation values for smoking and fewer arguments 
compared to non-smoking adolescents. As a result of participating in the program, cigarette smoking among adolescent smokers is significantly reduced, thus we conclude that the computer-based prevention program can be successfully applied to the adolescent population.

Keywords: smoking, prevention, informatics

Disciplines: psychology, informatics

Csibi Mónika és Csibi Sándor (2019): Számítógépes dohányzás-prevenció az iskolában. Mesterséges intelligencia - interdisz̧ciplináris folyóirat, I. évf. 2019/1. szám. 53-64.

doi: 10.35406/MI.2019.1.53

A WHO adatai szerint a dohányfüggőség a dohányfogyasztók felének halálát okozza, ez évente több, mint 7 millió embert jelent világszerte (WHO, 2017). A becslések szerint körülbelül 440 ezer amerikai hal meg évente a dohányzáshoz kapcsolódó betegségek miatt, közülük 90\% (396 ezer) serdülőkorban kezdett el dohányozni (CDC, 2014). Ez az oka annak, hogy a dohányzás napjaink egyik legelterjedtebb gyermek- és serdülőkori kockázati magatartásaként van számon tartva, annak ellenére, hogy befolyásolását számos ismertető, prevenciós vagy abbahagyást elősegítő iskolai program célozza. A 2017 felmérések eredményei szerint az Amerikai Egyesült Államokban a 12. osztályosok 9,7 százaléka, a 10. osztályosok 5,0 százaléka és a 8. osztályosok 1,9 százaléka használt cigarettát az elmúlt hónapban (Miech és mtsai., 2017). A gyermekek és serdülők a legveszélyeztetettebb korosztály a dohányzás elkezdése és kialakulása szempontjából (CDC, 2014). Előzetes ismeretek szerint a serdülők fejlődésbeli sajá- tosságaiból adódóan a nikotin hatással van az agy jutalmazási rendszerére és az érzelmi és kognitív funkciókban érintett agyterületekre (Smith és mtsai, 2015). Pénzes, Czeglédi, Balázs és Urbán (2017) követéses vizsgálatukban kimutatták, hogy a fiúk és a lányok hasonló arányban maradnak dohányzók, de a kutatásuk három éve alatt több lány szokott rá a cigarettára, mint fiú. Ugyanakkor, ebben a három éves időszakban a diákok 14,3\%-a szokott rá a cigarettára, de a leszokás aránya csak 3,3\% volt Pénzes, Czeglédi, Balázs és Urbán, 2017).

A serdülőkori dohányzási viselkedés megváltoztatásának folyamatát több pszichológiai elmélet és modell ismerteti. Közülük kutatásunk a T'TM modellhez igazodik leginkább, amely a viselkedésmódosítást egy dichotómiás folyamatként érzékelteti, ahol a változásra készséget mutató személyek eltérő attitűdökkel és meggyőződésekkel rendelkeznek, mint azok, akik még csak nem is gondolkodnak a változásokról (Brick és mtsai., 2017). A vál- 
tozásról szóló egyéni jellemzők lehetnek például a döntési egyensúly, az önhatékonyság, stb., amelyet az előnyök és hátrányok hozzáadott értékének mérésével mutatnak ki (Velicer és mtsai., 1985, Guo és mtsai., 2009). Így, azok a dohányzók, akik tudatában vannak a potenciálisan egészséget veszélyeztető magatartásuk jelenlétének és következményeinek, inkább motiváltak a dohányzási szokások abbahagyásában (Denford és mtsai., 2017). A kutatások az abbahagyási kísérletek indokaiként a jövőbeni egészséggel (73\%), a fizikai megjelenéssel (59\%), a cigaretta árával $(52 \%)$ és a sportteljesítménnyel (51\%) kapcsolatos aggodalmakat azonosították (Rinfel és mtsai., 2011). Pikó és Varga (2014) vizsgálatai rámutattak, hogy a serdülők gyakran az énmegerôsítés és a coping (megküzdés) céljából kezdik el a szerfogyasztást.

Az egészségre káros viselkedések, és ezen belül a dohányzási magatartás megváltoztatásában a belső motiváció megváltoztatása elsődleges, amit orvosi közegben leginkább egy személyközpontú tanácsadási módszerrel, a „motivációs interjú” alkalmazásával lehet elérni (Lindson-Hawley, Thompson és Begh, 2015; Pócs, Hamvai és Kelemen, 2017). A belső motivációk megtalálása, valamint a kogníciók, meggyőződések mintázatának feltérképezése egyre fontosabbá válik a serdülőkori dohányzási magatartás visszaszorításának szempontjából. Így megerôsítést nyert, hogy az egyéni intervenciók mellett, a csoportos prevencióban szükség van olyan gyakorlati, dohányzókra fókuszáló kurzusokra is, ahol a dohányzásról való leszoktatás módszereinek alapjait is elsajátíthatják a dohányzók
(Pikó, 2008), de magát a leszoktatást leginkább speciális szakemberre bíznák (Rinfel és mtsai., 2011).

Kutatásunk célja, hogy a serdülők dohányzásra késztető motivációit felmérjük, valamint a dohányzás prevenciós és intervenciós programok elvégzése után jelentkező motiváció-átstrukturálódásokat elemezzük. Feltételezéseink szerint a nemdohányzó serdülők motivációit mélyítik, megerősítik a program nyújtotta információszolgáltatások, az esztétikai és szociális motivációk átadják helyüket a megküzdési és egészségi állapottal kapcsolatos motivációknak. A már dohányzó serdülőknél a program a pro smoking motivációk szignifikáns csökkenését, valamint a cons smoking motivációk jelentős növekedését eredményezik.

\section{Minta}

A romániai ASPIRA kutatásban eredetileg 16 marosvásárhelyi középiskola 79 kilencedik osztálya, szám szerint 2002 serdülő vett részt (Nădăşan és mtsai., 2016). A kutatás során több serdülő hiányzott az első vagy második tesztelés során, vagy a számítógépes prevenciós programot nem követte végig, ezért végül a végleges minta 1369, 15-16 év közötti serdülőből tevődött össze. A program hatékonyságának mutatójaként a módosított Fagerström Tolerancia Kérdőív alkalmazásával (mFTQ - modified Fagerström Tolerance Questionnaire), a dohányzó mintát két csoportra osztottuk, alacsony mFTK és magas mFTK értékkel jellemzett serdülők, attól függetlenül, hogy a kísérleti vagy a kontroll csoport tagjai voltak vagy nem (kis mérték- 
ben dohányzó és szenvedélyes dohányzó). Így a teljes minta 1275, (93,1\%) alacsony mFTK értékkel, és 94 (6,9\%), magas mFTK értékkel jellemzett serdülőből állt. Nem szerinti eloszlásuk arányos, a kísérleti csoportban 39 fiú és 53 lány, a kontrol csoportban pedig 584 fiú és 691 lány.

\section{Eszközök}

Az ASPIRA számítógépes dohányzás prevenciós és intervenciós program egy 88 itemes kérdőívcsomag kitöltésével kezdődött, amely demográfiai, pszichoszociális és dohányzási szokásokkal kapcsolatos adatokat szolgáltatott. Az Internetes felületen található kérdőívet a számítástechnikai laborban egy óra alatt, kutatási asszisztensek felügyelete alatt végezték el. A kérdőívek kitöltése után, több egyórás alkalommal a serdülők online általános és orvosi információkat kapnak a dohányzásról, a dohányzás következményeirôl és korosztályukat célzó alternatív tevékenységekről. A program videókat, animációkat és interaktív tevékenységeket tartalmaz, a résztvevők képsorokat, kisfilmeket nézhetnek meg, orvosok, tanárok, valamint dohányzó serdülők beszámolóit hallgathatják meg A program célja, hogy információkat nyújtson, valamint a dohányzási attitűdök kognitív átstrukturálása által megelőzze a dohányzást, és leszokásra késztesse a már dohányzó serdülőket (Prokhorov és mtsai., 2010).

A dohányzás gyakoriságát az elmúlt 30 napban és naponta az elszívott cigaretták számával, valamint a dohányzási státusz változásait elemeztük, az alábbi kérdésekre adott válaszok segítségével: „Az elmúlt 30 napban bány napon cigarettázott?" (a válaszlehetőségek 0-egy napon sem, 1-egy-két napon, [...] és 6mindennap között helyezkednek el), „Kérjük, gondolja át azokat a napokat, az elmúlt 30 nap során, amikor cigarettázott. Hány cigarettát szivivott el azokban a napokban?" (0-egyet sem, 1- kevesebb, mint egy cigarettát naponta, [...] és 6 több, mint 20 cigarettát naponta) és „Az alábbi állitások közül melyik írja le a legjobban, bogy milyen gyakran cigarettázik?'(0-soha nem próbáltam ki, 1-egyszer megpróbáltam, de nem szívtam el végig, [...] és 11-több, mint egy csomaggal szívok el).

A kérdőívcsomag által tartalmazott, általunk felhasznált pszichológiai tesztek egyike a serdülőkre adaptált, módosított Fagerström Tolerancia Kérdőív (mFTQ, modified Fagerström Tolerance Questionnaire, Prokhorov és mtsai., 1998) amely a fizikai nikotinfüggés hét tünetét méri. Prokhorov és mtsai. (1998) javaslatai szerint, a hét mFTK item közül hatot négypontos skálával (0-3), a hetediket („A nap első két órájában többet dohányzol?”) bináris pontozással (igen $=1$, nem $=0$ ) használtuk. Mintánkban az mFTK kérdőív belső konzisztenciája az alapvizsgálatkor (Cronbach $\alpha=0,79)$ és utóvizsgálatkor (Cronbach $\alpha=0.69$ ) is jónak bizonyult.

A második alkalmazott kérdőív a 17 itemes Döntési Egyensúly Skála (DBS, Decisional Balance Scale, Plummer és mtsai., 2001), amely a dohányzási motivációkat vizsgálja. A skála dimenziói a dohányzás hátrányaira vonatkozó, egészségi (bealth cons) és esztétikai motivációkat (aesthetic cons), a dohányzást támogató előnyöket, megküzdést szolgáló érveket (coping pros) és a dohányzás melletti, tár- 
sas jellegú érveket (social pros) tartalmazza. A kérdőív itemei között szerepelnek, például „A dohányzás sárgára szinezi a fogakat.” (esztétikai motiváció), „A dobányzó gyermekeknek több barátjuk van.” (társas motiváció) vagy „A cigarettázás oldja a feszültséget." (megküzdési motiváció). A válaszlehetőségek „1 - egyáltalán nem fontos" és , 5 - nagyon fontos” között helyezkednek el. A kérdőív megbízhatósága vizsgálatunkban nagyon jónak bizonyult (Cronbach $\alpha=0,80)$. Az etikai előírások vizsgálata után, az etikai engedélyt egy marosvásárhelyi egyetem kutatási bizottsága szolgáltatta.

Az adatok statisztikai feldolgozása az SPSS programcsalád (SPSS, Inc., Chicago, IL, USA) PASW csomagjának 18 verziójával történt. Az elemzések deskriptív statisztikai mu- tatókkal, kétváltozós t-teszttel, valamint az intervenciós csoportban Wilcoxon előjeles rangszám próba segítségével történtek.

\section{Eredmények}

A dohányzó serdülók magasabb dohányzás melletti motiváció értékeket, valamint kevesebb dohányzás elleni érveket mutatnak a nem dohány zó serdülók.kel szemben.

A teljes mintán, a dohányzási motivációk (DES) tekintetében, azok a serdülők, akiknek mFTK értékeik nagyobbak, magasabb Dohányzás melletti értékeket, de kisebb Dohányzás elleni értékeket mutatnak, ez a tendencia a Pro-Cons különbség értékeiben is fellelhető (1. táblázat).

1. táblázat: A dohányzási motivációk mintázata az mFTK értékele szerint, a kutatás kezdeti és végsö szakaszában, a teljes mintában (kétváltozós t tesz.). Forrás: a Szerzőo

\begin{tabular}{|c|c|c|c|c|c|c|c|c|c|}
\hline \multirow[t]{2}{*}{ Változók } & \multirow[t]{2}{*}{ Kutatási szakasz } & \multicolumn{4}{|c|}{$\begin{array}{c}\text { Alacsony mFTK érték } \\
(\mathrm{N}=1275)\end{array}$} & \multicolumn{4}{|c|}{$\begin{array}{c}\text { Magas mFTK érték } \\
(\mathrm{N}=94)\end{array}$} \\
\hline & & Átlag & St.szórás & t-érték & $\mathrm{p}$ & Átlag & St.szórás & t-érték & $\mathrm{p}$ \\
\hline \multirow{2}{*}{ Social Pros } & Alapvizsgálat & 4.52 & 1.77 & \multirow{2}{*}{-1.21} & \multirow{2}{*}{0.22} & 5.71 & 2.56 & \multirow{2}{*}{0.50} & \multirow{2}{*}{0.61} \\
\hline & Utóvizsgálat & 4.59 & 1.91 & & & 5.58 & 2.56 & & \\
\hline \multirow{2}{*}{ Coping Pros } & Alapvizsgálat & 5.19 & 2.41 & \multirow{2}{*}{-1.18} & \multirow{2}{*}{0.23} & 8.07 & 3.18 & \multirow{2}{*}{1.81} & \multirow{2}{*}{0.07} \\
\hline & Utóvizsgálat & 5.28 & 2.50 & & & 7.55 & 2.90 & & \\
\hline \multirow{2}{*}{ Pros alskála } & Alapvizsgálat & 9.71 & 3.46 & \multirow{2}{*}{-1.44} & \multirow{2}{*}{0.14} & 13.78 & 4.62 & \multirow{2}{*}{1.55} & \multirow{2}{*}{0.12} \\
\hline & Utóvizsgálat & 9.87 & 3.84 & & & 13.13 & 4.66 & & \\
\hline \multirow{2}{*}{ Health Cons } & Alapvizsgálat & 12.87 & 2.86 & \multirow{2}{*}{9.49} & \multirow{2}{*}{$<0.01$} & 10.73 & 3.74 & \multirow{2}{*}{0.46} & \multirow{2}{*}{0.64} \\
\hline & Utóvizsgálat & 11.76 & 3.60 & & & 10.54 & 3.84 & & \\
\hline \multirow{2}{*}{ Aesthetic Cons } & Alapvizsgálat & 11.30 & 3.14 & \multirow{2}{*}{5.51} & \multirow{2}{*}{$<0.01$} & 8.85 & 3.61 & \multirow{2}{*}{-0.55} & \multirow{2}{*}{0.57} \\
\hline & Utóvizsgálat & 10.69 & 3.48 & & & 9.07 & 3.60 & & \\
\hline \multirow{2}{*}{ Cons alskála } & Alapvizsgálat & 24.12 & 5.52 & \multirow{2}{*}{8.15} & \multirow{2}{*}{$<0.01$} & 19.58 & 6.80 & \multirow{2}{*}{-0.04} & \multirow{2}{*}{0.96} \\
\hline & Utóvizsgálat & 22.46 & 6.67 & & & 19.61 & 6.79 & & \\
\hline \multirow{2}{*}{ Pro-Cons különbség } & Alapvizsgálat & -14.41 & 6.70 & \multirow{2}{*}{-7.97} & $<001$ & -5.79 & 9.42 & 078 & 043 \\
\hline & Utóvizsgálat & -12.58 & 7.97 & & $<0.01$ & -6.47 & 9.06 & 0.18 & 0.43 \\
\hline
\end{tabular}


$\mathrm{Ha}$ az adatokat az intervenciós-kontroll csoport szerint elemezzük, az eltérések egyre inkább kirajzolódnak, kiéleződnek. Ugyanakkor a kontroll csoportba tartozó, nem dohányzó serdülők a DES értékei nem mutatnak szignifikáns különbségeket a dohányzó fiataloknál, de a nem dohányzók esetében a Pros alskála értékei relatív stabilak, a Cons alskála értékei viszont jelentősen csökkennek. szerint nem mérvadó, a dohányzási érvek tekintetében nincs jelentős változás (2. táblázat). Az intervenció teljes mértékben eredményes az intervenciós csoportban, a dohányzó serdülők esetében, ahol a dohányzási motivációk dohányzás melletti értékei csökkennek (a Coping Pros jelentős mértékben), a Dohányzás elleni értékek pedig szignifikáns mértékben emelkednek, ami arra utal, hogy a

2. táblázat. A dohányzási motivációk mintázata az mFTK értékele szerint, a kutatás kezdeti és végsö szakaszában, az intervenciós csoportban (kétváltozós t tesżt).

\begin{tabular}{|c|c|c|c|c|c|c|c|c|c|}
\hline \multirow[t]{2}{*}{ Változók } & \multirow[t]{2}{*}{ Kutatási szakasz } & \multicolumn{4}{|c|}{$\begin{array}{l}\text { Alacsony mFTK érték } \\
\qquad(\mathrm{N}=641)\end{array}$} & \multicolumn{4}{|c|}{$\begin{array}{c}\text { Magas mFTK érték } \\
(\mathrm{N}=34)\end{array}$} \\
\hline & & Átlag & St.szórás & t-érték & $\mathrm{p}$ & Átlag & St.szórás & t-érték & $\mathrm{p}$ \\
\hline \multirow{2}{*}{ Social Pros } & Alapvizsgálat & 4.45 & 1.83 & \multirow{2}{*}{-0.79} & \multirow{2}{*}{0.42} & 5.44 & 2.36 & \multirow{2}{*}{0.00} & \multirow{2}{*}{1.00} \\
\hline & Utóvizsgálat & 4.52 & 1.93 & & & 5.44 & 2.31 & & \\
\hline \multirow{2}{*}{ Coping Pros } & Alapvizsgálat & 5.19 & 2.49 & \multirow{2}{*}{-1.18} & \multirow{2}{*}{0.23} & 8.14 & 3.05 & \multirow{2}{*}{2.04} & \multirow{2}{*}{0.04} \\
\hline & Utóvizsgálat & 5.33 & 2.56 & & & 7.14 & 2.61 & & \\
\hline \multirow{2}{*}{ Pros alskála } & Alapvizsgálat & 9.64 & 3.62 & \multirow{2}{*}{-1.21} & \multirow{2}{*}{0.22} & 13.58 & 4.49 & \multirow{2}{*}{1.51} & \multirow{2}{*}{0.14} \\
\hline & Utóvizsgálat & 9.85 & 3.98 & & & 12.58 & 4.25 & & \\
\hline \multirow{2}{*}{ Health Cons } & Alapvizsgálat & 12.56 & 3.07 & \multirow{2}{*}{7.54} & \multirow{2}{*}{$<0.01$} & 10.85 & 3.79 & \multirow{2}{*}{-1.93} & \multirow{2}{*}{0.06} \\
\hline & Utóvizsgálat & 11.27 & 3.88 & & & 11.91 & 3.39 & & \\
\hline \multirow{2}{*}{ Aesthetic Cons } & Alapvizsgálat & 11.00 & 3.22 & \multirow{2}{*}{3.38} & \multirow{2}{*}{$<0.01$} & 9.17 & 3.64 & \multirow{2}{*}{-3.57} & \multirow{2}{*}{$<0.01$} \\
\hline & Utóvizsgálat & 10.45 & 3.66 & & & 10.94 & 3.61 & & \\
\hline \multirow{2}{*}{ Cons alskála } & Alapvizsgálat & 23.56 & 5.81 & \multirow{2}{*}{5.90} & \multirow{2}{*}{$<0.01$} & 20.02 & 6.78 & \multirow{2}{*}{3.31} & \multirow{2}{*}{$<0.01$} \\
\hline & Utóvizsgálat & 21.72 & 7.20 & & & 22.85 & 6.55 & & \\
\hline \multirow{2}{*}{$\begin{array}{l}\text { Pro-Cons } \\
\text { különbség }\end{array}$} & Alapvizsgálat & -13.91 & 6.98 & \multirow{2}{*}{-5.86} & $<001$ & -6.44 & 8.71 & 178 & $<001$ \\
\hline & Utóvizsgálat & -11.87 & 8.58 & & $<0.01$ & -10.26 & 8.08 & $1 . / 8$ & $<0.01$ \\
\hline
\end{tabular}

Az intervenciós program alkalmazása után a dobányzó serdülók dohányzási motivációi átrendezoódnek, a dohányzás ellen fordulnak.

Az intervenciós csoportban, a nemdohányzó serdülők esetében fennmarad a kontrollcsoportnál leírt tendencia, tehát a prevenció területén a program hatékonysága adataink dohányzó serdülők értékrendszere, dohányzási motivációi átrendeződnek, a dohányzás ellen fordulnak, teljesen ellenkező tendenciát mutatnak a dohányzó, de az intervencióban nem részesülő serdülők eredményeivel. 
Az intervenciós program alkalmazása után az elszivott cigaretták száma jelentösen csökkent a dobányzó serdülōk körében.

A fentiekben leírt eredményeket megerősítô vizsgálatokkal támasztottuk alá. Az intervenciós csoportot a dohányzás gyakorissága (havonta és naponta) és a dohányzási státusz (elszívott cigaretták száma) szerint elemeztük. A dohányzásra vonatkozó kérdések: (1) „Az elmuilt 30 napban hány napon cigarettázott?", (2) „Kérjük, gondolja át azokat a napokat, az elmúlt 30 nap során, amikor cigarettázott. Hány cigarettát szivott el azokban a napokban?” és (3) „Az alábbi állitások közül melyik irja le a legjobban, hogy milyen gyakran cigarettázike?'. Az intervenció előtt és után adott válaszok közötti különbségek az elszívott cigaretták számát, a dohányzással jellemzett napok számát és az önjellemzett dohányzási státusz változásait mutatják.

A Wilcoxon előjeles rangszám próba különböző tendenciákat mutatott ki a dohányzás gyakoriságának mindhárom elemzett változója esetében. A magas mFTK értékű intervenciós csoportban esett a dohányzás gyakorisága, de a a különbség statisztikailag nem mérvadó. Például, a dohányzás havi gyakorisága tekintetében nem szignifikáns csökkenést tapasztaltunk - a medián poszt-tesztek rangjai $\mathrm{Mdn}=5$, az alaptesztelés rangjai pe$\operatorname{dig} \mathrm{Mdn}=4,5$ voltak. A magas mFTK értékű kontroll csoportban, statisztikailag jelentős növekedést mutattunk ki mindhárom dohányzási mutató esetében. Így, a három elemzett változó medián poszt-tesztjeinek rangjai $\operatorname{Mdn}=5, \operatorname{Mdn}=3, \operatorname{Mdn}=8$, az alap- tesztelés rangjai pedig $\operatorname{Mdn}=4, \operatorname{Mdn}=4$, $\mathrm{Mdn}=7$ voltak.

Az alacsony mFTK értékkel jellemzett intervenciós csoportban a havi cigarettázás gyakorisága szignifikánsan nőtt, ugyanígy a napi cigarettafogyasztás is jelentős mértékben emelkedett és az önjellemzett dohányzási státusz nagy mértékű dohányzásról számol be. $\mathrm{Az}$ alacsony mFTK értékkel jellemzett kontroll csoportban a cigarettázás gyakorisága (havi és napi gyakoriság, dohányzási státusz) jelentősen növekedett a két tesztelés közötti időszakban $(p<0.01, p<0.01, p<0.01)$.

\section{Megbeszélés}

Kutatásunkban az ASPIRA (Prokhorov és mtsai., 2010) számítógépes dohányzás prevenciós és intervenciós program magyar nyelvű verziójának (Nădăşan és mtsai., 2016) marosvásárhelyi alkalmazásából szerzett adatokat elemezzük, különös figyelemmel a dohányzási motivációk jellemzőire, valamint a program hatékonyságára. A program eredményességét a dohányzói viselkedés súlyosságának mértékével tettük összefüggésbe, a kis mértékben dohányzó-, valamint a szokássá rögzült dohányzó serdülők közötti összehasonlítások következtében. Cohen, Myers és Kelly (2002) szerint a nikotinfüggőség jelentôs tényezôt jelent a serdülők dohányzási kitartásában. Az mFTK eredményei szerint kimutatott függoóség terminus serdülőknél való alkalmazásával szemben a szerzők óvatosságra intenek (Cohen, Myers és Kelly, 2002). Más szerzők vizsgálatai szerint az alkalmi do- 
hányosok idősebb korban kezdtek dohányozni, naponta kevesebb füstöt szívtak be, és szignifikánsan alacsonyabb értékeket értek el a függőségi skálán, de ugyanolyan nehézségekkel küzdöttek, mint a napi dohányzók, amikor megpróbálták abbahagyni a dohányzást (Rubinstein és mtsai., 2014). Kutatásunkban a dohányzás súlyosságát az mFTK kérdőívvel mértük, amely jelenleg a kutatások szerint a nikotinfüggóség olyan egyfaktoros mérőeszköze, amely elfogadható belső konzisztenciát és érvényességet mutat több országban való alkalmazás során (Prokhorov és mtsai., 2017). Eredményeink szerint a dohányzás súlyossági foka meghatározhatja, az intervenció lejárta után, a dohányzási motivációk eredményes szerveződését.

A serdülők dohányzási motivációinak mintázata eredményeink szerint különbözik a dohányzás súlyosságának, szokássá rögzülésének függvényében. Így, a dohányzó, nagyobb mFTK értékkel jellemzett serdülők több dohányzás mellett szóló érvet (Pros) sorakoztatnak fel, de ugyanakkor kevesebb dohányzás elleni motivációt (Cons) mutatnak. A teljes mintán, a kisebb mFTK értékeket elérő serdülők jelentősen nagyobb dohányzás elleni motiváció értékeket értek el az intervenció után, mint előtte. Ez a tendencia az egészséggel kapcsolatos ellenérvek, az esztétikai ellenérvek és az összesített dohányzás elleni motiváció tényezőt is végigkísérte.

Ha mintánkat az intervenciós, illetve kontroll csoporthoz tartozás szerint elemezzük, adataink kimutatják, hogy csoporthoz tartozástól függetlenül is, a keveset dohányzó fiatalok Dohányzás melletti értékei relatív stabi- lak, a Dohányzás elleni értékei viszont jelentősen csökkennek a legtöbb serdülő esetében. Egyes kutatások szerint a serdülőket korban előrehaladva, több olyan jellegzetes pszichés tényező befolyásolja, amelyek összefüggenek a dohányzási magatartással, mint például a szenzációkeresés, (Cservenka, 2013; Csibi és mtsai., 2015), vagy az önértékelés (Hale és mtsai., 2015; Sargent és mtsai., 2017).

Pénzes, Czeglédi, Balázs és Urbán (2017) kutatásai szerint a cigarettára rászokás, illetve leszokás folyamata magyar serdülők körében növekvő tendenciát mutat. Eredményeik alapján rámutattak, hogy a napi rendszerességű dohányzás gyakorisága a fiatalabb korosztályban több mint négyszeresére, az idősebb csoportban pedig közel kétszeresére növekedett a nagyobb mértékű emelkedést a lányoknál lehetett megfigyelni (Pénzes, Czeglédi, Balázs és Urbán, 2017).

Az intervenciós program szerintünk temperálja ezt a folyamatot és eléri, hogy a dohányzási magatartás a kezdeti szinten maradjon, ha nem is tudja ezt jelentősen csökkenteni.

$\mathrm{Az}$ intervenció teljes mértékben eredményes az intervenciós csoportban, a dohányzó, magas mFTK értékkel jellemzett serdülők esetében, ahol a dohányzási motivációk Dohányzás melletti értékei csökkennek (a Coping Pros jelentős mértékben), a Dohányzás elleni értékek pedig szignifikáns mértékben emelkednek. A kortársak befolyása jelentősen csökken, a belső, megküzdési motivációk felerősödnek, a serdülők pedig tudatosítani kezdik, feltehetőleg a program által nyújtott információk hatására, a dohányzás veszélyeit. 
A program hatékonyságát más mutatókkal is megvizsgáltuk, ezek a dohányzás gyakorisága (havonta és naponta) és a dohányzási státusz (elszívott cigaretták száma). Az alacsony mFTK értéket elért serdülőknél, a cigarettázás gyakorisága (havi és napi gyakoriság, dohányzási státusz) nőtt a két tesztelés között, de ez a viselkedésminta jellemző serdülőkre, ahol a kor előrehaladtával jelentôsen emelkedik a dohányzási viselkedések száma (Pénzes, Czeglédi, Balázs és Urbán (2017).

A magas mFTK értékeket elért, kontroll csoportba tartozó serdülőknél mindhárom mutató szerint az elszívott cigaretták száma emelkedett. Az intervenciós csoportban fordított hatást észleltünk, tehát a dohányzás gyakoriságának mutatói statisztikailag szignifikáns csökkenést jeleztek. Adataink alapján mondhatjuk, hogy az ASPIRA program hatására, a már szokás szinten dohányzó serdülők cigarettafogyasztása jelentősen csökken, tehát a program sikeresen alkalmazható, intervenciós szinten, serdüló populáción.

Kutatásunk esetleges gyenge pontja, hogy mintánkat nem tekinthetjük országos szinten reprezentatívnak, a vizsgálat alatt pedig különböző okok miatt a serdülők egy része kilépett a vizsgálatból, ezért eredményeinket sem általánosíthatjuk a teljes serdülő populációra.

Erôs pont viszont, hogy a marosvásárhelyi középiskolák reprezentatív mintáján történt, és az intervenciós tevékenység az alaptesztelés és utótesztelés között, hat hónapos időintervallumot vett igénybe, megerősítve adatainkat. Ugyanakkor, vizsgálatunk a prevenciós és intervenciós program hatásait követte a dohányzási viselkedés mélyebb struktúráira, valamint a dohányzási motivációk mintázatát tárta fel, kiemelve ezen programok alkalmazásának szükségességét.

\section{Következtetés}

A serdülők dohányzási magatartását, vizsgálatunkon belül a cigarettafogyasztását hatékonyan befolyásolhatjuk pozitív irányba, ha online, számítógépen (esetleg okostelefonon) elérhető prevenciós programokat alkalmazunk. Ezeknek a hatásmechanizmusa komplex, néha nehezen kimutatható, de pozitívan befolyásolja a serdülők dohányzással kapcsolatos attitűdjeit, motivációstruktúráit. Pénzes, Czeglédi, Balázs és Urbán (2017) kutatási adatai alátámasszák, hogy intervenció hiányában az általános iskolás korosztályban a rendszeres cigarettahasználat évről évre szinte megduplázódik. Guo és mtsai. (2009) szerint a dohányzók és nemdohányzók közötti különbségek elemzése bizonyítja, hogy a döntési egyensúly megváltoztatása viselkedésben bekövetkező változásokhoz vezet. Eredményeink szerint a külső, dohányzás melletti motivációk (mint például a szociális motiváció) mélyebb, belső dohányzás elleni érvekké alakulnak (például a dohányzás elleni, megküzdési motivációk) és elősegítik a cigarettafogyasztás visszaszorítását és akár a teljes abbahagyást.

\section{Összefoglalás}

A serdülőkori dohányzás a felnőttkori egészségi állapot egyik legjelentősebb kockázati magatartása. A prevenciós és leszokást tá- 
mogató programok hatékonyságának növelése céljából fontos a korai beavatkozás, valamint a serdülők szempontjából vonzó (például informatikai eszközökön is alapuló) módszerek alkalmazása.

Longitudinális kutatásunk prevenciós és leszokási beavatkozás elvégzése után jelentkező motiváció-átstrukturálódásokat elemez, valamint a számítógépes, iskolai beavatkozások hatékonyságát vizsgálja.

Módszer: az ASPIRA számítógépes dohányzás prevenciós és intervenciós program 6 hónapig tartó applikációja, valamint a program előtt és után kérdőívcsomag alkalmazása. A dohányzás gyakoriságát az elmúlt 30 napban és naponta az elszívott cigaretták számával mértük. A program hatékonyságának megvizsgálása céljából a résztvevőket két csoportra osztottuk a módosított Fagerström Tolerancia Kérdőív magas, illetve alacsony pontszámai alapján. A kérdőív tartalmazta a Döntési Egyensúly Skálát, amely a dohányzási motivációkat vizsgálja. Mintánk 16 marosvásárhelyi középiskola 16 osztályát, 1369, 1516 év közötti serdülőit tartalmazta.

Eredményeink szerint a dohányzó serdülők magasabb dohányzás melletti motiváció értékekkel és kevesebb dohányzás elleni érvekkel jellemezhetők a nem dohányzó serdülőkkel szemben. Az intervenciós program alkalmazása után a dohányzó serdülők dohányzás melletti motivációi csökkennek, míg a dohányzás hátrányaira fókuszáló motivációi szignifikáns mértékben emelkednek. Az intervenciós csoportban, a dohányzó serdülőknél esett a dohányzás napi és havi gyakorisága, a kontroll csoportban pedig statisztikailag jelentős növekedést észleltünk mindhárom dohányzási mutató esetében.

A program hatására az intervenciós csoportban, a magas mFTK értéket elért serdülőknél a dohányzási motivációk dohányzás melletti értékei csökkennek, a dohányzás elleni értékek pedig szignifikáns mértékben emelkednek. A dohányzó serdülők cigarettafogyasztása jelentősen csökken, így szerintünk az online számítógépes program sikeresen alkalmazható, intervenciós szinten, serdülő populáción.

\section{Irodalom}

Brick L. et al. (2017): Intervention effects on stage transitions for adolescent smoking and alcohol use acquisition. Psychology of addictive behaviors 31; 614. doi: 10.1037/adb0000302

Cohen, L.M., Myers, M.G. \& Kelly J.F. (2002): Assessment of nicotine dependence among substance abusing adolescent smokers: A comparison of the DSM-IV criteria and the modified Fagerström Tolerance Questionnaire. Journal of Psychopathology and Behavioral Assessment 24; 225-233. doi: 10.1023/A:1020722915204

Cservenka, A., Herting, M.M., Seghete, K.L., Hudson, K.A. \& Nagel, B.J. (2013): High and low sensation seeking adolescents show distinct patterns of brain activity during reward processing. Neuroimage 66; 184-193. doi: 10.1016/j.neuroimage.2012.11.003

Csibi M., Nădăşan V., Bálint I., Csibi S., Dénes M., Ábram Z. (2015): Differences in the sensation-seeking and depressive symptoms related to high school students' 
smoking status. Acta Medica Marisiensis 61, (Suppl 8); 17.

Denford S., Abrahan, Ch., Van Beurden, S., Smith, J. R. \& Morgan-Trimmer, S. (2017): Behaviour-change interventions for public health. In Tsekleves, E. \& Cooper, R. (eds.): Design for Health. London: Routledge. 58-71. doi: 10.4324/9781315576619-25

Guo, B., Aveyard, P., Fielding, A. \& Sutton, S. (2009): The Factor Structure and Factorial Invariance for the Decisional Balance Scale for Adolescent Smoking. Int J Behav Med. 16; 158-163. doi: 10.1007/s12529008-9021-5

Hale, W. J., Perrotte, J. K., Baumann, M. R. \& Garza, R. T. (2015): Low self-esteem and positive beliefs about smoking: A destructive combination for male college students. Addictive behaviors 46; 94-99. doi: 10.1016/j.addbeh.2015.03.007

Lindson-Hawley N., Thompson T.P. \& Begh R. (2015): Motivational interviewing for smoking cessation. [Online]. Accessed: 30th March 2018. Web: http://www.the healthwell.info/node/115326

Miech R., Schulenberg J., Johnston L., Bachman J., O'Malley P. \& Patrick M. (2017): Monitoring the Future National Adolescent Drug Trends in 2017: Findings Released. Ann Arbor, MI: Institute for Social Research, The University of Michigan. Accessed: March 30, 2018.Web: http://www.monitoringthefuture.org//pr essreleases/17drugpr.pdf

Nădăşan, V., Foley, K.L., Pénzes, M., Paulik, E., Mihăicuță, Ș., Ábrám, Z., Bálint, J., Csibi, M. \& Urbán R. (2016): The short- term effects of ASPIRA: a web-based, multimedia smoking prevention program for adolescents in Romania: a cluster randomized trial. Nicotine \& Tobacco Research 19; 908-915. doi: 10.1093/ntr/ntw308.

Pénzes M., Czeglédi E., Balázs P.és Urbán R. (2017): Dohányzói életutak magyar serdülók körében [Smoking trajectories among Hungarian adolescents]. Orv Hetil. 158; 67-76. doi: 10.1556/650.2017.30629

Pikó B. és Varga Sz. (2014): Mi motiválja a fiatalok dohányzását és alkoholfogyasztását? Magatartás-epidemiológiai elemzés [What motivates smoking and alcohol drinking of young people? A behavioural epidemiologic study]. Orv Hetil. 155; 100-105. doi: 10.1556/OH.2014.29805

Pikó B. (2008): Study of smoking behavior and smoking-related attitudes among preclinical medical students. Orv Hetil. 149; 2471-2478. doi: 10.1556/OH.2008.28516

Plummer, B.A., Velicer, W.F., Redding, C.A., Prochaska, J.O., Rossi, J.S., Pallonen, U.E. \& Meier, K.S. (2001): Stage of change, decisional balance, and temptations for smoking: Measurement and validation in a large, school-based population of adolescents. Addictive behaviors 26; 551-571.

Pócs D, Hamvai Cs and Kelemen O. (2017): Magatartás-változtatás az egészségügyben: a motivációs interjú. Orv Hetil. 158; 1331 1337. doi: 10.1556/650.2017.30825

Prokhorov, A.V., Kelder, S.H., Shegog, R., Conroy, J.L., Murray, N., Peters, R., Cinciripini, P.M., De Moor, C., Hudmon, K.S. \& Ford, K.H. (2010): Project ASPIRE: an Interactive, Multimedia Smoking 
Prevention and Cessation curriculum for culturally diverse high school students. Substance use \& misuse 45; 983-1006. doi: 10.3109/10826080903038050.

Prokhorov, A.V., Khalil, G. E., Foster, D. W., Marani, S.K., Guindani, M., Espada, J. P., Gonzálvez, M. T., Idrisov, B., Galimov, A., Arora, A., Tewari, A., Isralowitz, R., Lapvongwatana, P., Chansatitporn, N., Chen, X., Zheng, H. \& Sussman, S. (2017): Testing the nicotine dependence measure mFTQ for adolescent smokers: A multinational investigation. The American journal on addictions 26; 689-696. doi: 10.1111/ajad.12583

Prokhorov, A.V., Koehly, L. M., Pallonen U. E. \& Hudmon K. S. (1998): Adolescent Nicotine Dependence Measured by the Modified Fagerström Tolerance Questionnaire at Two Time Points. Journal of Child \& Adolescent Substance Abuse7; 35-47. doi: 10.1300/J029v07n04_0 $\underline{3}$

Rinfel, J., Oberling, J., Tóth, I., Prugberger, L. \& Nagy, L. (2011): Medical students' smoking habits and attitudes about cessation. Orvosi hetilap 152; 469-474. doi: 10.1556/OH.2011.29039

Rubinstein, M. L., Raita, M. L., Sen, S. \& Shiffman, S. (2014): Characteristics of adolescent intermittent and daily smokers. Addictive behaviors 39; 1337-1341. doi: 10.1016/j.addbeh.2014.04.021

Sargent, J. D., Gabrielli, J., Budney, A., Soneji, S. \& Wills, T. A. (2017): Adolescent smoking experimentation as a predic- tor of daily cigarette smoking. Drug \& Alcohol Dependence 175; 55-59. doi: 10.1016/j.drugalcdep.2017.01.038

Smith, R. F., McDonald, C. G., Bergstrom, H. C., Ehlinger, D. G., Brielmaier, J. M. (2015): Adolescent nicotine induces persisting changes in development of neural connectivity. Neurosci Biobehav Rev. 55; 432-443. doi: 10.1016/j.neubiorev.2015.05.019

U.S. Department of Health and Human Services 2014. The Health Consequences of Smoking - 50 Years of Progress: A Report of the Surgeon General. Atlanta: U.S. Department of Health and Human Services, Centers for Disease Control and Prevention, National Center for Chronic Disease Prevention and Health Promotion, Office on Smoking and Health. Aaccessed: 2018 march 30. Web: https:/ /www.ncbi.nlm. nih.gov/ pubmed/24455788

Velicer, W. F., DiClemente, C. C., Prochaska, J. O. \& Brandenburg, N. (1985): Decisional balance measure for assessing and predicting smoking status. J Pers Soc Psychol 48; 1279-1289. doi: 10.1037/ / 0022-3514.48.5.1279

WHO. Report on the global tobacco epidemic, 2017. Monitoring tobacco use and prevention policies. Geneva: World Health Organization. Licence: CC BY-NC-SA 3.0 IGO. 
MÓDSZERTANI TANULMÁNYOK 


\title{
FILMKLUBOK SZEREPE \\ A MESTERSÉGES INTELLIGENCIÁVAL KAPCSOLATOS ATTITÜDÖK FORMÁLÁSÁBAN
}

\author{
Szerző: \\ Mező Ferenc (PhD) \\ $\mathrm{K}+\mathrm{F}$ Stúdió $\mathrm{Kft}$ \\ Mező Katalin (PhD) \\ Debreceni Egyetem \\ Mező Kristóf Szíriusz \\ Kocka Kör \\ Első szerző e-mail címe: \\ ferenc.mezo1@gmail.com
}

\author{
Lektorok: \\ Koncz István (PhD, CSc) \\ Professzorok az \\ Európai Magyarországért Egyesület \\ Váró Kata Anna (DLA) \\ Debreceni Egyetem \\ ...és további két anonim lektor
}

\begin{abstract}
Absztrakt
Manapság a filmek fontos szerepet játszanak a mesterséges intelligenciával (MI) kapcsolatos attitűdök alakításában. Következésképpen a filmklubok, amelyek az „MI filmekre” összpontosítanak, hatékonyak lehetnek a mesterséges intelligenciához való hozzáállás formálásában. Ez a cikk egyrészt az „MI filmek” egy (1908-tól 2019-ig terjedő) gyűjteményét mutatja be a Filmklubok számára; másrészt módszertani javaslatokat nyújt az „MI” Filmklubok alapításához és szervezéséhez.
\end{abstract}

Kulcsszavak: mesterséges intelligencia (MI), film, attitűd

Diszciplina: pszichológia, pedagógia

\begin{abstract}
ROLE OF FILM CLUBS

IN FORMING OF ATTITUDES TOW ARD ARTIFICLAL INTELLIGENCE

Nowadays movies have important roles in forming attitudes about artificial intelligence (AI). Consequently the Film Clubs, which focus on 'AI films', can be effective in shaping the attitudes towards artificial intelligence. This article, on the one hand, shows a collection of 'AI films' (form 1908 to 2019) for Film Clubs. On the other hand, it gives methodological recommendations for founding and organizing Film Clubs in order to shape attitudes towards artificial intelligence.
\end{abstract}

Keywords: artificial intelligence (AI), film, attitude

Discipline: psychology, pedagogy

Mező Ferenc, Mező Katalin és Mező Kristóf Szíriusz (2019): Filmklubok szerepe a mesterséges intelligenciával kapcsolatos attitűdök formálásában. Mesterséges intelligencia - interdiszciplináris folyóirat, I. évf. 2019/1. szám. 67-94. doi: 10.35406/MI.2019.1.67 
A robotokkal, s általában véve a mesterséges intelligenciákkal (MI) való együttműködés megköveteli, hogy megtanuljuk kezelni e gépeket, szoftvereket, megértsük működésüket, hasznukat és felhasználásuk esetleges veszélyforrásait is. Mindehhez szükséges azonban, hogy tárgyilagos véleményt, attitűdöt alakítsunk ki velük kapcsolatban. Ugyanakkor akár társadalmi szinten is különbségek mutatkozhatnak abban, hogy miként viszonyul, milyen attitűdökkel fordul a népesség a robotokkal, a mesterséges intelligenciával felé(lásd például: MacDorman, Vasudevan és Ho, 2009; Riek és tsai, 2010). A mesterséges intelligencián alapuló fejlett technikát az azt elfogadni tudó/akaró társadalom fogja eredményesebben használni a közeljövőben - s ezzel a hozzáállással várhatóan gazdasági előnyökhöz is fog jutni egy-egy MI-barát társadalom.

Az ember-MI együttmúködés azonban nemcsak a technológia fejlődésére hat, hanem az emberi attitűdökre, intenciókra, viselkedési sémákra is hatással lehet. Goux-Baudiment (2014) szerint az ember-robot hibrid munkacsoportok létrehozása megköveteli, hogy az emberek precízebben fejezzék ki magukat, utasításaik és kérdéseik rövidek és céltudatosak legyenek. Az embereknek meg kell tanulniuk például, hogy a kreativitás (még sokáig) emberi feladat lesz, a monoton, algoritmizálható feladatsorok - vagy, mint Takayama, Ju és Nass (2008) fogalmaz: a piszkos, veszélyes és unalmas munka végzését azonban a mesterséges intelli- genciára lehet majd bízni. Mindezek mögött persze az az előfeltevés áll, hogy létezik ideális megoldás az ember-MI munkamegosztás tekintetében. Ezt az együttműködést azonban össztársadalmi szinten tanulnunk kell majd.

E tanulási folyamat vélhetően könnyebb lesz, ha már valóban intelligens, univerzális háztartási robotok között élünk. Azonban amíg ez nincs így, addig az emberek számára a saját élményen alapúló tanulás helyett a mesterséges intelligenciáról másoktól - tudósoktól, múvészektôl, tanároktól, médiából, vagy akár kortársaktól szerzett információk jelentik az inputot saját attitűdjük, viselkedésük (= output) alapjául - vö.: a humán információfeldolgozás OxIPO-modelljével (Mező, és Mező, 2019).

Az emberek mesterséges intelligenciával kapcsolatos (vélt vagy valós ismerteket, érzelmeket és viselkedési szándékokat magába foglaló) attitűdjét (vö.: Allport, 1954) a tudományos igényű ismeretek, hírek mellett (megkockáztatjuk: olykor helyett!) a népszerű képregények, könyvek, s filmek alakítják (Brown, 2016). Ez utóbbiak történeteinek megismerése révén egyrészt (esetenként tév) ismereteket szereznek a mesterséges intelligenciával kapcsolatban, másrészt a szereplőkkel történő azonosulás révén, a szociális (modellkövetéses, vikariáló) tanulás során normákat, attitúdöket is elsajátítanak.

Megjegyzés: A vikariáló tanulás lényege: egy személy megtekinti egy modell (például 


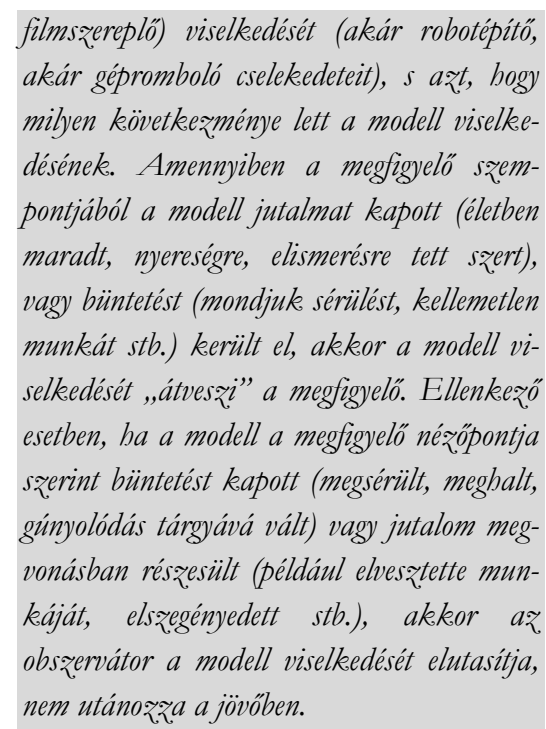

Riek, Adams és Robinson (2011) különböző kulturális hátterű és korú vizsgálati személyeiknek ( $n=287$ ) például hat olyan filmet mutattak be (cím szerint: Artificial Intelligence; I, Robot; Metropolis; Surrogates; Terminator and 2001: A Space Odyssey), melyben a robotok negatív színben tüntek fel, és hat olyan filmet (címük: Bicentennial Man, Moon, Short Circuit, Star $W$ ars, and $W$ all-E), amelyben a robotok pozitív szereplőként voltak bemutatva. Eredményeik szerint a vizsgálati személyek által nézett robotos filmek mennyisége és különösen a robotokat pozitív színben feltüntető filmek nézése pozitívan korrelál a robotokkal kapcsolatos pozitív attitűddel. A Bicentennial Man, a Moon és a Wall-E címü filmek megtekintése után volt a legpozitívabb attitűd tapasztalható a robotokkal szemben. Bartneck és tsai (2007) hasonló eredményekről számolnak be. Az eredmények alátámasztják Allport (1954) teóriáját arról, hogy az attitűdtárggyal (esetünkben például: a robotokkal, legalábbis filmbeli ábrázolásukkal) történő gyakori találkozás elősegíti a vele kapcsolatos pozitív attitűd kialakulását, az előítéletek oldását.

Amennyiben a filmeknek, különösen a népszerü játékfilmeknek ilyen jelentős hatása van a mesterséges intelligenciával kapcsolatos közvélemény alakulására, akkor ez azt is jelenti, hogy a filmek által a nézők attitűdje egyrészt megismerhető, másrészt szükség esetén formálható is lehet. Filmklubok szervezése így elősegítheti a mesterséges intelligenciára fókuszáló:

- pedagógiai, pszichológiai és/vagy piackutatás jellegü diagnosztikát: az MI témával kapcsolatos közvélemény és közhangulat (szűkebb értelemben egy adott célcsoport, például tanulói, munkahelyi közösség) hozzáállásának felmérését;

- nevelést: szocializálást, szemléletformálást, attitűdök kialakítását vagy akár a mesterséges intelligenciához viszonyulással kapcsolatos videós önismeretfejlesztést (vö.: Koncz, 2012)

- oktatást: diszciplináris és interdiszciplináris, illetve tantárgyi és tantárgyközi komplexitást szolgáló ismeretátadást.

Sajátos módon nemcsak a tudományos kutatások inspirálhatják a filmmúvészeti alkotások létrehozóit, hanem fordítva: a kutatók, innovátorok is ihletet meríthet- 
nek a művészektől. Ezért akár innovátorok, kutatók számára is szervezhető MI filmklub. Esetükben a cél nemcsak a kikapcsolódás lehet, hanem a teljesítménynövelést célzó újabb inputok, ihletek nyújtása is.

Joggal merülhet fel azonban a kérdés, hogy: Léteznek-e mesterséges intelligencia témájú filmek? Ha léteznek, akkor miként szervezhetünk filmklubot? Hogyan tervezzünk meg egy adott filmklub foglalkozást? Milyen kérdésköröket, témákat vethetünk fel a mesterséges intelligenciára fókuszáló filmklubok esetében? Milyen feladatokat, élménypedagógiai elemeket alkalmazhatunk a gamifikáció (játékosítás) jegyében a filmklubok során? Jelen tanulmány ezekre a kérdése reflektál dióhéjban.

\section{Mesterséges intelligencia témájú játékfilmek}

Magyar szerzők/gyártók által készített mesterséges intelligenciával is foglalkozó, azt szerepeltető játékfilmek közül négy klasszikust kell kiemelnünk.

Az első: Pirx kapitány kalandjai. 1972ben készült, öt részes magyar filmsorozat, mely Stanislaw Lem Pirx pilóta kalandjai címú műve alapján készült. Számítógépen futó - mai szóhasználattal mesterséges intelligenciának nevezhető - programok, robotok egyaránt előfordulnak a sorozatban. Rendezők: Kazán István és Rajnai András. Gyártó: Magyar Televízió Művelődési Főszerkesztőség.
A második Mézga Aladár különös kalandjai című, 1972-ben készült, 13 epizódból álló rajzfilmsorozat. Ennek különösen a 4. része (epizód címe: Masinia) kötődik a mesterséges intelligencia témához: a Masinia bolygó lakói addig tökéletesítették gépeiket, amíg azok átvették a hatalmat. Forgatókönyv: Nepp József és Romhányi József. Rendező: Nepp József. Gyártó: Pannónia Filmstúdió.

A harmadik a Mikrobi címü, 1973-1975 között készült 13 epizódból álló magyar rajzfilmsorozat. Mikrobi egy univerzális háztartási robot, gyermekekre felügyelő komikus, pozitív figura. Forgatókönyvíró: Dr. Botond-Bolics György és Bálint Ágnes. Rendező: Mata János. Gyártó: Pannónia Filmstúdió.

Végül a negyedik: Az. idő urai (Les Maîtres du temps) című, 1982-ben francia, magyar, brit, nyugat-német és svájci kooprodukcióban készült sci-fi rajzfilm. Alapmű: Stefan Wul „L'Orphelin de Perdide" című alkotása. Forgatókönyv: Jean Giraud (Moebius), René Laloux és Jean-Patrick Manchette. Gyártó: Télécip, TF1 Films Production, WDR, SWF, SSR, BBC, Pannónia Filmstúdió és Hangarofilm.

Érzékelhető, hogy nem bővelkedünk a téma hazai filmes feldolgozásaiban, s az említett alkotások is 30-40 éve keletkeztek. A kis számú hazai MI vonatkozású játékfilm mellett azonban szélesebb választékot találunk az 1908-2019 (júniusáig) tartó időszakot átölelő, több, mint 200 külföldi játékfilmet tartalmazó (sajnos 
még nem teljes, ám fejlesztés alatt álló) adatbázisból (Dirks, 2015 és Net1). Az egyes évtizedek filmtermését az 1. ábra szemlélteti.

Az első „robotos” filmek már a némafilmes hőskorban megjelentek (Dirks, 2015), s a téma a hangos filmes korszakban is követőkre talált. Múfaját tekintve úttörő és/vagy jellegzetes mesterséges intelligencia vonatkozású...

...akció/kaland filmnek tekinthetó az Undersea Kingdom (1938, USA), amelyben távvezérelt robotok (Volkitek) állnak a fógonosz rendelkezésére. Rendező: B. Reeves Eason és Joseph Kane.

1. ábra: mesterséges intelligencia tartalmú külföldi játékfilmek 1920-2019 (jünius) között (forrás: a Szerzőolk)

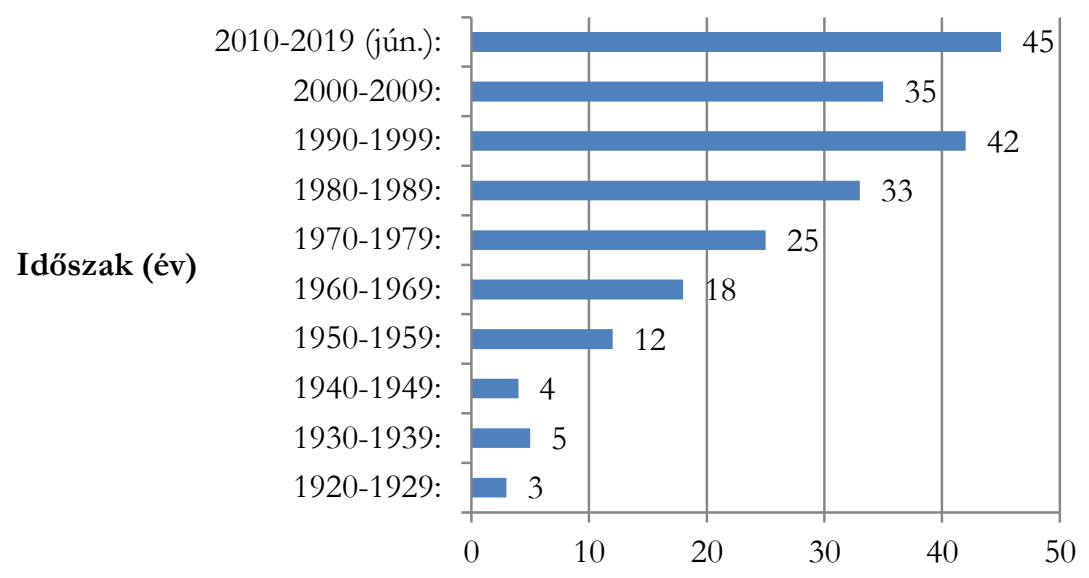

Mesterséges intelligencia tartalmú játékfilm (db)

...thriller a Jack Gold által 1937-ben rendezett, UK és Nyugat-Német kooprodukcióban készült „Who?”, melyben Roboman (egy „robotikus kiborg”, android) is szerepel.

...horror film George Waggner „Man Made Monster" címú 1941-ben, az USAban készült alkotása, melyben egy Dan
McCormick nevú mutatványost kegyetlen kiborggá „Dynamo”-vá alakítanak. A filmben megjelenik az alkotója ellen forduló teremtmény, s így a robotoktól való félelem motívuma is.

...vígjáték a The Perfect Woman (1949, UK, rendező: Bernard Knowles), benne az Olga névre hallgató MI-vel. 
...romantikus film, melyet férfi rendezett, $\mathrm{s}$,női” robotot mutat be: a már említett 1949-es The Perfect Woman. A nô által rendezett és "férfiként" ábrázolt robotot bemutató romantikus filmek úttörője a Susan Seidelman által rendezett 1987-es Making Mr. Right, melyben a robot neve Ulysses.

...rajzfilm az 1941-ben, az USA-ban készült összesen kilenc perc időtartamú „The Mechanical Monsters", amelyben a főhős Superman egy őrült tudós által vezérelt robot hadsereggel küzd meg. A filmet Dave Fleischer rendezte.

Tekintettel arra, hogy a mesterséges intelligencia téma köré szerveződő filmklubok néhány klasszikus, pionír film mellett várhatóan inkább koncentrálnak a frissebb, korszerúbb filmekre, célszerú áttekinteni - a mai gyermekek, fiatal felnőttek korában született - legutóbbi három évtized vonatkozó filmtermésének volumenét. A mellékletben található (sajnos korántsem teljes) adatbázisban az elmúlt harminc évben kétszáznál több (zömében USA-beli) alkotás található (nem számítva a Star Wars, a Star Trek filmekre épülő nagyszámú sorozatepizódot). Figyelemre méltó, hogy a mesterséges intelligencia tartalmú külföldi játékfilmek évi átlaga a legutóbbi három évtizedben: kb. 4 film/év.

Összességében megállapítható, hogy a mesterséges intelligencia témára épülő filmklubok múködtetéséhez rendelkezésre áll az a filmmennyiség (vö.: melléklet), amiből a filmklubok szervezôi válogathatnak. A következő kérdés azonban az, hogy miként szervezhető filmklub.

\section{Filmklubok szervezése}

Filmklubnak tekintjük az egyének és vagy csoportok számára szervezett olyan filmvetítéssel egybekötött alkalmakat, melyek meghatározott témában és céllal szerveződnek és a résztvevők a filmvetítés előtt vagy azt követően beszélgetés, előadás keretében osztják meg egymással gondolataikat.

A filmklub szerveződése kétféleképpen történhet (és ennek megfelelően a filmklub szervezője kétféleképp választhat a filmek közül): szó lehet a Nemzeti Filmiroda adatbázisában bejegyzett filmklubról, illetve oktatási céllal múködő szabad felhasználású filmek vetítésével foglalkozó filmklubról.

A bejegyzett filmklub létrehozásakor a klubot regisztrálni kell a Nemzeti Filmiroda adatbázisában. Ennek a nyilvántartásba vételen túl gyakorlati haszna is van, mivel csak regisztrált szervezetek indulhatnak az Nemzeti Kulturális Alap (www.nka.hu) által kiírt olyan pályázatokon, amelyeken jogdijakra, valamint előadói díjakra, reklámköltségekre is igényelhetnek támogatást a filmklubok). Az eljárás díja körülbelül bruttó $30.000 \mathrm{Ft}$.

A regisztrált filmklubok esetében a jogszerű filmvetítésnek három további követelménye van (Berze, 2018 alapján): 
- Filmvetitési jog megszerzése, ami a forgalmazótól vagy annak meghatalmazottjától, vagy a terjesztőtől kapható meg. A filmvetítési jogot szerződésben kell rögzíteni.

- A filmzene lejátszás jogának megszerzése: erre akkor van szükség, ha a filmvetítési jogot megadó szerződésben nem szerepel, hogy a filmzene lejátszásának jogdíját a forgalmazó vagy a terjesztő fizeti be. Ilyen esetben a filmvetítést végző szervezetnek kell utólag rendeznie a filmzene lejátszásával kapcsolatos jogdíjat az ARTISJUS (Magyar Szerzői Jogvédelmi Iroda Egyesület) felé.

- Hivatalos (jogtiszta) kópia beszerzése: a hivatalos kópiát annak a szervezetnek kell adnia, amellyel a filmvetítési jogról szóló szerződés meg lett kötve. Speciális esetben, ha a filmvetítési jogot megadó szervezet nem rendelkezik hivatalos kópiával, akkor azt kereskedelmi forgalomból, illetve a gyártótól kell beszerezni. Másrészt jogtisztának tekinthetô minden kópia, ami legális forrásból, legális szolgáltatás keretében érhető el online streaming vagy letöltés formájában.

A filmvetítési jog, a filmzene lejátszási jog és a hivatalos kópia beszerzése átlagosan 20.000 $\pm 5.000 \mathrm{Ft}+$ ÁFA összeg körül alakult 2018-ban.

A másik filmklub működési lehetőség az oktatási céllal müködö, szabad felhasználású filmek vetitésével foglalkozó filmklub szervezése. Ebben az esetben célszerü olyan filmeket választani a filmvetítési alkalmakra, amelyek a szabad felhasználás hatálya alá esnek, mivel egyéb esetben az elkészüilt filmalkotások felhasználása után dijazás illeti meg a szerzổket. Díjazás hatókörébe tartozik például a sokszorosítás, a terjesztés, a közvetítés, valamint a magáncélú másolás is (Lukács, 2015).

A szabad felhasználás lehetővé teszi a szerzői jog által védett művek (beleértve kép, hang, szöveg, a filmalkotás és más audiovizuális mû - a továbbiakban együtt: filmalkotás) díjmentes felhasználását, így többek között idézését, meghatározott törvényi feltételek között. A hatályos magyar szerzői jogi törvény (1999. évi LXXVI. törvény a szerzői jogról) a szabad felhasználásról a következő rendelkezéseket tartalmazza:

„33. \ (1) A szabad felhasználás körében a felhasználás díjtalan, és ahhoz a szerző engedélye nem szükséges. Csak a nyilvánosságra hozott mûvek használhatók fel szabadon e törvény rendelkezéseinek megfelelően.

(2) A felhasználás a szabad felhasználásra vonatkozó rendelkezések alapján is csak annyiban megengedett, illetve díjtalan, amennyiben nem sérelmes a mú rendes felhasználására és indokolatlanul nem károsítja a szerző jogos érdekeit, továbbá amennyiben megfelel a tisztesség követelményeinek és nem irányul a szabad felhasználás rendeltetésével össze nem férô célra.

(3) A szabad felhasználásra vonatkozó rendelkezéseket nem lehet kiterjesztően értelmezni. 
(4) E fejezet rendelkezéseinek alkalmazása szempontjából az iskolai oktatás célját szolgálja a felhasználás, ha az az óvodai nevelésben, az általános iskolai, középiskolai, szakmunkásképző iskolai, szakiskolai oktatásban, az alapfokú művészetoktatásban vagy a felsőoktatásról szóló törvény hatálya alá tartozó felsőfokú oktatásban a tantervnek, illetve a képzési követelményeknek megfelelően valósul meg".

Azaz, az oktatási célú vetitések - tehát azok, melyek köznevelési vagy felsőoktatási intézmény tantervének vagy képzési követelményeinek megfelelően valósulnak meg - szabad felhasználásnak minösülnek, ezért ezekért a szerzőket nem illeti meg dijazás. Viszont ,ha az alkotást nem vizsgafilmként, illetve oktatófilmként használják fel a tanterv, illetve képzési követelmények keretében, hanem nyilvánosan egyéb módon vetitik. például fesztivál, filmes tábor, filmklub vagy egyéb felhasználás keretében, az közvetve a jövedelemszerzés célját szolgálja, igy a szuroóket dijazás illeti meg utána. Ehhez engedélyt kell kérni a szerzőktől és a szerzői jogosultaktól (forgalmazóktól), valamint jogdíjat is kell fizetni az Artisjus Magyar Szerzői Jogvédő Iroda Egyesület felé.

Az oktatófilm nem üzletszerű kiadásához és forgalmazásához akkor nem szükséges a jogosultak engedélye, ha a filmet tananyaggá minősíttetik. Maga az oktatófilm mindezektől függetlenül az általános szabályok szerint (egyéni-eredeti jelleg) szerzői műnek minősülhet” (Lukács, 2015).
Ebből következően, abban az esetben, ha szabad felhasználású filmvetítést szeretnénk elérni a filmklub-szervezés során, tanmenetet, foglalkozási tervet kell készíteni a filmklub megkezdése előtt, a filmklub teljes időszakára vonatkozóan. A filmklubra az éves tervnek megfelelőn kiválasztott filmek sorrendjében célszerú levetíteni, a vetítések után pedagógiai, oktatási célú megbeszéléseket, előadásokat kell tartani.

\section{Egy adott}

\section{filmklub foglalkozás szervezése}

Egy adott filmklub foglalkozás szervezésének főbb fókuszpontjai: a célcsoport kiválasztása, a filmek kiválasztása, a helyszín és időpont és időbeosztás megválasztása, a résztvevők verbuválása/meghívása, a program megtervezése.

A célcsoport kiválasztása. A célcsoport kiválasztása során különösen lényeges a korosztály megfelelő kiválasztása, mivel a filmek tartalma a különböző korcsoportokban eltérő hatásokat fejthetnek ki. A Magyarországon forgalmazott filmek többnyire korhatárjelzéssel vannak ellátva (2. ábra). A korhatár besorolás azt mutatja, hogy az adott film megtekintése, hány éves kor alatt tartalmaz a gyermekek és fiatalok szellemi fejlődésére veszélyes vagy káros tartalmakat.

Mozifilmek esetén a 2004. évi II. törvény a mozgóképről alapján a Nemzeti Média- és Hírközlési Hatóság (NMHH) dönt a besorolásról (ennek érdekében a filmforgalmazók kötelesek minden film- 
2. ábra: Médiatartalmak korhatár besorolása (Forrás: NMHH, 2011)

A korhatárra tekintet nélkül megtekinthetõ músorokat a csatornáknak nem kell jelöléssel ellátniuk, és bármikor bemutathatók.

A 6 éven aluliak számára nem ajánlott mũsor a megfelelő jelzéssel bármikor vetíthetô, de 6 éven aluliaknak szánt músorszámok között nem tehetố közzé.

12. A 12 éven aluliak számára nem ajánlott müsorok a jelzéssel bármikor adásba kerülhetnek, kivéve a 12 éven aluliaknak szánt müsorszám között.

A 16 éven aluliak számára nem ajánlott músorok csak 21 óra és hajnali 5 óra között vetíthetők.

A 18 éven aluliak számára nem ajánlott müsorok csak 22 óra és hajnali 5 óra között vetíthetök.

jük egy példányát legalább 30 nappal a bemutató előtt benyújtani az NMHH-hoz korhatár-besorolás céljából).

A televízióban vetített filmek esetén az egyes csatornák végzik a korhatár besorolást $-6,12,16$ és 18 éves korhatárokat állapítanak meg - a 2010. évi CLXXXV. törvény (Médiatörvény) alapján, s az NMHH ajánlása alapján és ellenőrzése alatt. A filmklub célcsoportjának kiválasztásánál feltétlenül figyelembe kell venni a korhatár besorolást, mivel ezek az adatok életkori ajánlást jelentenek (2. ábra).

A célcsoport kiválasztás másik szempontja az érdeklődés, mivel a film élményszerző tevékenység, így célszerű, hogy csak azok csatlakozzanak a filmklubba, akik nyitottságot, kedvet éreznek a programban való részvételre, ebből következően fontos, hogy a filmklub soha ne legyen kötelező.
A célcsoport kiválasztásának harmadik szempontja a filmklub szervezői által elérendô, a célcsoport sajátosságaihoz igazodó cél (például: azoknak a fiataloknak szervezünk mesterséges intelligenciára témára fókuszáló filmklubot, akiket be szeretnénk vonni további MI projektekbe).

Filmválasztás. A filmválasztás lényegesebb szempontjai (mely elsősorban a filmklub vezetőjét terhelő probléma): a filmklub célja, a film témája, múfaja, hoszsza, megbeszélés utáni felhasználása.

A filmklub helyszinének meguálasztása. A filmklub helyszínéül szolgálhat a létszámhoz igazodó nagyobb terem, vagy klubszoba, amelynek lesötétíthetô ablakai vannak, és ahol biztosított a zavartalan, zajmentes filmnézés lehetősége. Technikai feltételként célszerú vetítővásznat, vetítőgépet (akár: számítógépet és projektort), valamint kihangosító berendezést biztosí- 
tani a „filmélmény” megvalósítása érdekében. Ettől függetlenül időnként egy nagyképernyős televízió is alkalmas lehet a filmvetésére. A másik véglet: moziterem bérlése.

Idóbeos:táas. A filmklub alkalmak kiválasztását a csoport és a filmklubot szervezô szabadideje befolyásolja. Valószínúleg a havi egy alkalmas filmklub program megvalósítása jellemzőbb, mint a gyakoribb szervezés, de ez az adott csoporthoz igazodóan változhat.

A filmklub alkalmak szervezésénél figyelembe kell venni a levetítésre kerülő film hosszát (ami gyakran 1-3 órát is igénybe vehet), valamint az az előtti, vagy az azt követő előadás, megbeszélés hoszszát is (ami szintén akár 1-3 óra is lehet).

Mindezek ismeretében kell közös megegyezésre jutni a filmklub alkalmak gyakorisága terén. Létezik olyan megoldás is, ami során egy hosszabb filmet több részletben néznek meg, s az egyes részek elótt is alkalmaznak „bemelegítō", felvezető, felidéző beszélgetéseket, s a filmrészletek után is van megbeszélés.

Tájéko oztatás a filmklubról. Már beindult, vagy múködő filmklub esetében a filmvetítési alkalmakat a szervezô és a tagok közösen beszélik meg.

A filmvetítés hirdetése már reklámnak minősül (ami után a szerzőket szerzői dij illeti meg), így a szabad felhasználású filmeket vetítô filmklub esetében ezt nem célszerú alkalmazni. Ebben az esetben a filmklub-alkalom szervezése folyhat személyesen, vagy közösségi oldalakon kialakított zárt, mások által nem látható csoportokban.

A filmklub programjának tervezése. A programtervezés egyrészt vonatkozik a filmklub által egy múködési időszakban (évben, hónapban) értelmezett programra, másrészt az egyes filmes foglalkozások, alkalmak programjára.

A távlati értelemben vett programterv például az alábbi pontokat tartalmazhatja:

Filmklub neve: ...

Célja: ...

Múkëdtetóje: ...

Filmklubon belül futó programsorozat neve (tekintve, hogy egy filmklub több programot is müködtetbet párbuzamosan): ...

Programsorozat célja: ...

Programsorozat célközönsége: ...

Programsorozat keezdōe és záró dátumai:

Programsorozat inten ritása: ... alkalom/ hónap

Alkalmak:

1. alkalom:

1.1. Meghirdetésének módja: ...

1.2. Meghirdetésének dátuma:

1.3. Dátum..., -tól-ig idópont: .......

1.4. Helyszin: ....

1.5. Film: ...

1.6. A foglalkozás végére elérendón cél: ...

1.7. Meghivott elöadó (ha van): ....

1.8. A felevezetó foglalkozást, elöadást tartó személy: ... 


\subsection{A megvitató/ levezetó foglalkozást tartó} személy...

\subsection{Költségek:}

1.10.1. Filmvetitési jog dija: ...

1.10.2. Filmzene lejátszásának jogdija: ...

1.10.3. Hivatalos kópia dija: ...

1.10.4. Terembérleti dij: ...

1.10.5. Tiszteletdijak (klubvezetönek, meghivott elöadónak, közremüködöknek):...

1.10.6. Reprezentáció, étkeratetés költsége (ha van):....

1.10.7. Egyéb (utaztatás, es₹köz költség, járulékok stb., ha vannak): ...

1.10.8. Várható költségek összesen: ...

1.11. Bevételek:

1.11.1. Önrész: ...

1.11.2. Résquételi dij (ha van): ...

1.11.3. Pályázati forrás (ha van): ...

1.11.4. Támogatás, szpon zoráció: ...

1.11.5. Önkéntes munka révén történö megtakaritás: ...

1.11.6. Egyéb: ...

1.11.7. Várható bevétel összesen: ...

1.12. Bevétel-költség: ...

n. alkalom:

n.1. Meghirdetésének módja: ...

n.2. Meghirdetésének dátuma:

n.3. Dátum..., -tól-ig idöpont: .......

n.4. Helyszin: ...

n.5. Film: ...

stb., stb.

Programsorozat összes várható költsége: ...

Programsorozat összes várható bevétele: ...

Programsorozat összességét tekintve a

bevétel-költség különböz̨ete: ...
Egy adott filmklubos alkalom általános programterve pedig a következőképpen alakulhat (természetesen nem kötelező jelleggel, hanem csak ajánlásként):

1) Megjelentek köszöntése (1-2 percben).

2) A Filmklubban megvalósuló aktuális programsorozat nevének és céljának bemutatása (max. 2 percben).

3) Rövid (kb. 5 perces) összefoglaló a programsorozat eddigi történéseiről (megtekintett filmek, meghívottak, kialakult vita lényege, konklúziók) és/vagy ráhangoló játékok, gyakorlatok végzése.

4) Rövid előadás az adott alkalommal megtekintésre kerülő filmről (5-20 percben a megtekintésre kerülő film hosszától is függően).

5) Szempontok adása a film nézéséhez, s a film megtekintését követő megbeszéléshez.

Filmklubok alkalmával az. MI témához.
kapcsolódó szempont lehet például:
- Milyen típusú MI-t (pl. szoftvert, vagy
robotot) mutat be a film?
- Pozitív vagy negativ karakterként jele-
níti-e meg a film az MI-t?
- Hogyan viszonyulnak a mesterséges in-
telligenciához a szereplók?
- Megfigyelhetö-e változás az MI, illetve a
szereplók. MI-hez való viszonyulásában?
- Milyen irányú ez a változás? Mi lehet
ennek. az oka?
- Milyen történeti kontextusba ágyazza a
film az. MI-t?
- Mi lehet a filmben a fikció és mi lehet a
tudományos tény az. MI-vel kapcsolatban?


- Milyen audio-vizuális és/vagy 4D-s effektekekel, operatöri, rendezőir, diszlet- és jelmez̧beli hatásokekal éltek a film alkotói annak érdekében, hogy az. MI-t érintó jelenetek valamilyen attitüdöt formáljanak a nézóben?

- Mennyire tünik realisztikusnak a történet, s a szereplók reakciója egyes helyzetekben?

- Milyen tanulság vonbató le a filmböl? $s t b$.

6) A film megtekintése (részletekben vagy egészben). Mozifilmek esetében ez a rész 90-120 percet (vagy többet) is igénybe vehet.

7) Rövid (5-10 perces) szünet. Cél: átmozgatás, mosdóhasználat.

8) Beszélgetés a filmről. Javasolt időtartam: 15-120 perc (az eddig eltelt idő, s a közönség aktivitása függvényében).

9) Levezető gyakorlat, játék (5-10 perc).

10) Informálás a következő filmklub foglalkozásról és búcsúzás (5 perc).

\section{Filmklubhoz kapcsolódó beszélgető kör a mesterséges intelligenciával kap- csolatban}

A mesterséges intelligenciára fókuszáló filmklubok szervezése során kérdésként merülhet fel, hogy mégis milyen témakörökről eshet szó e rendezvények alkalmával.

A mesterséges intelligencia tematikájú filmklubbok esetében csoportvita, kerek- asztal beszélgetés, fórum keretében tárgyalható kérdéskörök lehetnek például:

1. Alapfogalmak. Cél: a mesterséges intelligencia témához tartozó fogalmakkal kapcsolatos tudásszint felmérése és/vagy nevelés, oktatás és/vagy megszerzett tudás ellenőrzése, illetve a mesterséges intelligenciával kapcsolatban a filmklub végére kialakult (megszilárdult vagy megváltozott) attitűd megismerése. Megjegyzés: az itt felsorolt kérdések a mesterséges intelligencia témakörrel éppen ismerkedő, előzetes tudást legfeljebb film- és irodalmi élményekből szerző résztvevői kört feltételez. Ennek fényében az alapfogalmak esetében nem célszerű a neurális hálók, a machine learning vagy deep learning világába belemélyedni. Ugyanakkor, ha a szükséges előzetes tudás és érdeklődés már rendelkezésre áll, akkor természetesen részletekbe menőbben is feldolgozhatók az alapfogalmak. A mesterséges intelligencia téma alapfogalmaira vonatkozó lehetséges kérdések például:

- Mit jelent az ,intelligencia” kifejezés?

- Mit jelent a „mesterséges intelligencia" kifejezés?

- Mi mesterséges intelligencia, s mi nem az?

- Mi az összefüggés a robot és a mesterséges intelligencia között?

- Mi az összefüggés a hardver és a szoftver kifejezések között?

- Miért kerülhetett a figyelem középpontjába a mesterséges intelligencia kutatása napjainkban? 
- Mi a tudomány és mi a fikció a mesterséges intelligencia kapcsán eddig megismert sci-fi, illetve dokumentumfilmekben?

- Létezik mesterséges intelligencia?

\section{Altalános filo zófiai, pszichológiai kérdések.} Cél: a mesterséges intelligenciával kapcsolatos elvont filozófiai kérdésektôl az etikai és emocionális jellegű felvetéseken át a praktikumra vonatkozó felvetések megvitatása akár tárgyilagosan, akár attitűdformáló jelleggel (a filmklub céljától függően). Ide vonatkozó kérdések lehetnek például:

- Mi az élet?

- Létezhet-e mesterséges élet?

- Él-e a mesterséges intelligencia?

- Lehet-e tudata, személyisége, érzelme, vágya a mesterséges intelligenciának?

- Barátságos vagy ellenséges érzelmekkel viszonyulnak az emberek a mesterséges intelligenciához? Miért?

- Az ember legjobb barátjává válhat-e egy mesterséges intelligencia?

- Menthet-e életet a mesterséges intelligencia?

- Meghosszabbíthatja-e az életet, ha intelligens múszerveket kapnak a sérült, beteg emberek?

- Létrehozható-e ember-gép hibrid (más szóhasználattal: kiborg, kibernetikus organizmus, gépember - vagy éppen gépnövény, -állat)?

- Ki a hibás, ha egy mesterséges intelligencia (például: robot, önvezérlő au- tó) balesetet okoz? A programozó, a gyártó, a kereskedő, a tulajdonos?

- Fellázadhatnak-e a gépek/szoftverek?

- Lehetnek-e jogai egy mesterséges intelligenciának?

- Hasznos vagy haszontalan a mesterséges intelligencia kutatása, alkalmazása? Miért?

3. Személyes attitüdök, ambiciók, pályaorientáció kérdésköre. Cél: a filmklub résztvevőinek a mesterséges intelligenciával, illetve annak kutatásával kapcsolatos személyes attitűdjeinek, ambícióinak, megismerése és/vagy beszélgetés révén történő formálása. E témakörhöz kapcsolódó kérdések lehetnek például az alábbiak:

- Te mire használnád a mesterséges intelligenciát? Miért?

- Te mire NEM használnád a mesterséges intelligenciát? Miért?

- Neked lenne-e kedved mesterséges intelligencia kutatásával, előállításával, használatával foglalkozni? Miért?

- Milyen tanulmányok/szakmák lehetnek szükségesek a mesterséges intelligencia kutatása, létrehozása terén? Miért?

- Mi a kedvenc tantárgyad, s az hogyan kötődik a mesterséges intelligencia kutatásához, létrehozásához?

- Mi a legkevésbé kedvelt tantárgyad, s az hogyan kötődik a mesterséges intelligencia kutatásához, létrehozásához (miért lesz e tantárgyra mégis 
szükséged, ha mesterséges intelligencia kutatással szeretnél foglalkozni)?

- Mi a hobbyd? Hogyan kötődik a mesterséges intelligencia kutatásához?

- Lenne-e kedved bekapcsolódni mesterséges intelligenciára vonatkozó tudományos diákkörbe, kutatócsoportba? Mit kell ehhez tenned?

\section{Filmklubos feladatillusztrációk}

A filmklubok egyes alkalmait színesebbé és emlékezetesebbé tehetjük, a résztvevőket aktivizálhatjuk és bevonhatjuk játékos feladatokkal is. Az alábbiakban következzék néhány feladattípus, melyeket a mesterséges intelligenciára fókuszáló filmklub foglalkozások keretében is alkalmazhatunk:

Film felismerése zene alapján: fel kell ismerni, hogy melyik dal melyik filmhez, kapcsolódik. Az nyer, aki a legtöbbet ismer fel. Alkalmazható egyrészt a filmklub elökészítő foglalkozásain az előzetes ismeretek felmérésére (kiderülhet, hogy legalábbis zenéjük alapján, mely filmek ismertek/ismeretlenek a résztvevők számára, s ez az információ segítheti a szervezőket a filmklub végleges programjának megtervezésében), illetve a filmklub hangulatának megteremtésére. A filmzenék felismerése másrészt a filmklub végén a megtekintett filmek összefoglaló felidézését elősegítő gyakorlat, kvízjáték is lehet.

Szerep-szinész párositás: a színészek képeit párosítani kell a neveikkel, illetve filmbeli szerepeikkel! Változat: film-rendező, film- forgatókönyvíró, film-MI párosítások elvégeztetése. A gyakorlat alkalmas lehet általában filmtörténeti ismeretek gyakoroltatására, s adott esetben MI-filmek tudatosítására, felidézésére is.

Film-barchoba: eldöntendő kérdésekre adott válaszok alapján ki kell találni, hogy a kérdezett személy melyik filmre gondolt! Változat: jelenet-barchoba (ki kell találni, hogy egy adott film melyik jelenetére gondolt valaki). Barchoba-játék esetében eldöntendő kérdésekre ,igen-nem” (vagy: zseblámpával adott piros fény $=$ nem, zöld fény = igen; felállás = igen, leülés $=$ nem) válaszok adhatók.

Film-activity: az activity játék szabályai szerint körülírás, elmutogatás vagy rajzolás alapján ki kell találni, hogy melyik filmről lehet szó. Változat: jelenet-activity (ki kell találni, hogy egy adott film melyik jelenetére gondolt valaki), vagy szereplőactivity (ebben az esetben a kérdés az, hogy egy film melyik szereplöjéről lehet szó). Szükséges felszerelés: vastag filctoll, flipchart vagy falra rögzíthető csomagolópapír, amire adott esetben rajzok készíthetők.

Film(részlet) szinkeronizálás: szinkronizálni kell egy filmet, filmrészletet. A szinkron szöveg lehet a filmklub vezetője által írásban adott vagy a szereplők által improvizált jellegű. Tartalmát tekintve a szöveg ragaszkodhat a filmbelihez vagy attól eltérhet. Akár az MI-vel kapcsolatos alapismeretekre fókuszáló, talán száraznak tưnő szöveg is figyelemfelkeltő lehet, ha azt a közönség egy mély férfihanggal bíró tag- 
ja olvassa fel miközben egy, a hanggal nem összeegyeztethető szereplő - mondjuk egy hercegnő? - karaktere pillant ránk a mozivászonról.

Videó felvétel készitése filmekhez, filmrészletekhez: adott film(részlet) hangjához a résztvevők által „házi feladatként” készített videó film lejátszása. A gyakorlat segítheti a filmrészlet tartalmának, az alkotók munkájának jobb meg- és átélését. Változat: a filmrészlet animációs verziójának elkészítése.

Film-kviæ: adott filmhez, témához tartalmazó műveltségi kérdések, képrejtvények, hang/zene felismerési feladatok adása egyénileg játszó vagy 4-6 fős csapatokban versenyző közönségnek. Ez a játék a filmmel/témával kapcsolatos tudásszint felmérésre és ismeret gyakoroltatásra is alkalmas. A játék tartalmazhat kiegészítendő kérdéseket vagy eldöntendő kérdéseket is. A válaszadás történhet szóban vagy írásban; igen/nem válaszok esetében kéz felnyújtással, felállással vagy leüléssel. 3-4 választási lehetőséget kínáló feleletválasztós feladat esetében a válaszadás megoldható úgyis, hogy a résztvevők a terem egyik vagy másik választ kifejező sarkába sétálnak, vagy 3-4 filmbeli karaktert ábrázoló hurkapálcikára rögzített bábu közül azt mutatják fel, amelyiket a csoport elōzőleg az a, b, c vagy d válaszhoz rendelt.

Film-alapú szabaduló szoba: egy filmklub foglalkozás zárásaként meglepetés játék lehet, ha az önkéntes résztvevők számára a film motívumaira épülő szabadulószoba jellegű játékot szervezünk. Ehhez szük- ség van 4-5 figyelmet, emlékezet, gondolkodást megmozgató feladatra, amik a helyiség egyes pontjain találhatók, s amelyek megoldása során nemcsak megtörténik a film és a filmklub eseményeinek, tartalmainak felidézése, hanem megtalálják a résztvevôk azt a kódsorozatot is, ami alapján a kijáratnál fémvázas széken elhelyezkedő ellenőr (az „élő szövet a fém vázon”) kiengedi a nyerteseket.

Egy filmbeli motivum fejlódésének filmtörténeti elemrése: egy adott motívum (példa: a „gyilkos robot” vagy éppen a „megmentó robot”) filmtörténeti feldolgozása, s adott kortörténeti, alkotói, tudományos és irodalmi milliőbe helyezése. Ilyen szempontból a mozi vagy a televízó filmtörténeti oktatásban játszott szerepe is feldolgozható (v.ö.:Váró, 2014).

\section{Összefoglalás}

Miközben egyre nagyobb figyelmet fordítunk a mesterséges intelligencia kutatására, az egyre nagyobb szerepet játszik az életünkben is. Vajon kellőképpen felkészültek vagyunk-e egy olyan világra, amelyben az ember és a gép merőben új módon fog együttmúködni? Vajon fel tudjuk erre készíteni a következő - a mesterséges intelligencia hétköznapi alkalmazásának korába folyamatosan „belenövő" - generációkat? Ki tudjuk alakítani azt az attitűdöt a társadalomban, ami révén a mesterséges intelligencia nem vetélytárs, nem mindenható eszköz, hanem az emberi létet és munkát segítő eszköz maradhat? 
A mesterséges intelligencia témát körbejáró filmklubok szervezése hasznos lehet a résztvevők témával kapcsolatos attitűdjeinek felmérésére, s szükség esetén formálására is. Erre azért nyílik lehetőség, mert amíg a potenciális résztvevőknek nem nyílik lehetősége a mesterséges intelligenciáról direkt módon információt szerezni, addig csak áttételesen, indirekt módon, a szóbeszéden, illetve az irodalmi- és filmélményeken (s vélhetôleg csak kisebb részben tudományos-ismeretterjesztő müvek olvasásán) keresztül tájékozódhatnak. A filmkultúra napjainkban nagy erôvel hat mindannyiunkra és jelentősen formálhatja a mesterséges intelligenciára vonatkozó beállítódásunkat is. Ezt a jelenséget pedagógiai eszközként is használhatjuk, amennyiben diagnosztikai, nevelési és oktatási céllal MI tematikájú filmklubot müködtetünk.

E tanulmányban igyekeztünk rámutatni arra, hogy mesterséges intelligenciát szerepeltető játékfilmek nagy számban léteznek (bár sajnos Magyarországi alkotóktól alig találunk ilyen múveket) - e filmek hiánya tehát nem lehet akadálya a MI filmklubok szervezésének.

A fentiekból az is kiderül, hogy milyen feltételek mellett üzemeltethető filmklub, hogyan tervezhető mesterséges intelligenciára épülő program(sorozat), s milyen kérdésköröket, játékos gyakorlatokat vethetünk fel az egyes vetítések alkalmával.

\section{Irodalom}

1999. évi LXXV 1. törvény a szerzői jogról.

Letöltés: 2019.06.22. Web:

https:// net.jogtar.hu/jogszabaly?docid $=99900076 . \mathrm{TV}$

2004. évi II. törvény a mozgóképroól. Letöltés:

2019.06.22. Web:

https:/ / net.jogtar.hu/jogszabaly?docid $=\mathrm{A} 0400002 . \mathrm{TV}$

2010. évi CLXXXV. törvény a médiaszolgáltatásokeról és a tömegkommunikációról. Letöltés: 2019.06.22. Web: https://net.jogtar.hu/jogszabaly?docid =A1000185.TV\&timeshift $=20190801$

Allport, G. W. (1954). The nature of prejudice. Cambridge, Mass.: AddisonWesley Publishing Company

Bartneck, C., Suzuki, T., Kanda, T. and Nomura, T. (2007): The influence of people's culture and prior experiences with Aibo on their attitude towards robots. AI and Society, 21:217-230, 2007. doi: 10.1007/s00146-006-0052-7

Berze L. (2018). Filmklub indításához tudnivalók. Nyilvános, interneten elérhetö levelezés. Letöltés: 2019.06.22. Web: https://listserv.niif.hu/pipermail/katal ist/2018-February/038160.html

Brown, K. (2016): The AI You're Looking For: Star Wars Technology Saves the Day. Honors Theses, AY 15/16. Wyoming Scholars Repository. letöltés: 2019.06.29. Web: https://pdfs.semanticscholar.org/3a5e / f4084e6ecbb1c2af54ea1 eefa012a8d65 c71.pdf 
Dirks, T. (2015): Robots in Film. A Complete Illustrated History of Robots in the Movies. Letöltés: 2019.06.22. Web: https:// www.filmsite.org/robotsinfilm1.html oldaltól a https://www.filmsite.org/ robotsinfilm15.html oldalig

Goux-Baudiment, F. (2014) "Sharing Our Humanity with Robots: What Does It Mean to be Human?" World Future Review. 6.4 (2014): 412-425. doi: $10.1177 / 1946756715569442$

Koncz I. (2012): Videós önismeretfejlesztés. Fapadoskönyv Kiadó, Budapest.

Lukács N. (2015). A filmalkotásokkal kapcsolatos szerzői jogok szabályozása Magyarországon. 1. rész. Filmtett, Erdélyi Filmes Portál. Letöltés: 2019.06.22. Web: https://www.filmtett.ro/cikk/ 4093/a-filmalkotasokkal-kapcsolatosszerzoi-jogok-szabalyozasamagyarorszagon-1-resz

MacDorman, K., Vasudevan, S. \& Ho, C. (2009): Does Japan really have robot mania? Comparing attitudes by implicit and explicit measures. AI \& Society, 2009, 23(4): 485-510. doi: 10.1007/s00146-008-0181-2

Mező Ferenc és Mező Katalin (2019): Az OxIPO-modell - az interdiszciplináris kutatások egy lehetséges értelmezési kerete. OxIPO - interdiszciplináris tudományos folyóirat, 2019/1, 9-21. doi: 10.35405/OXIPO.2019.1.9

Net1: List of artificial intelligence films. Letöltés: 2019.07.12. Web: https://en.wikipedia.org/wiki/List_of _artificial_intelligence_films.
NMHH (Nemzeti Média- és Hírközlési Hatóság)(2011). A kiskorúak védelme korhatár-besorolás. Letöltés: 2019.06.22. Web: http://nmhh.hu/cikk/187453/ A_kiskoruak_vedelme_korhatarbesor olas

Riek, L. D., Adams, A. \& Robinson, P. (2011). Exposure to Cinematic Depictions of Robots and Attitudes Towards Them. Lab Report. Cambridge (UK): University of Cambridge.

Riek, L. D., Mavridis, N., Antali, S., Darmaki, N., Ahmed, Z., Al-Neyadi, M. \& Alketheri, A. (2010): Ibn Sina steps out: Exploring Arabic attitudes toward humanoid robots. In In Proc. of The Second Int'l Symposium on New Frontiers in Human-Robot Interaction at AISB 2010, 2010

Takayama, L., Ju, W. and Nass, C. (2008): Beyond dirty, dangerous and dull: what everyday people think robots should do. Proceedings of the 3rd ACM/IEEE international conference on Human robot interaction, HRI 2008, Amsterdam, The Netherlands, March 12-15, 2008, pages 25-32, 2008. doi: $10.1145 / 1349822.1349827$

Váró K. (2014): A televízió helye a filmtörténet oktatásában. In Kis-Tóth L. (szerk.): Agria Media 2014, ICI 13, ICEM 2014 : Információtechnikai és Oktatástechnológiai Konferencia és Kiállitás. 2014. október 8-10. Eszterházy Károly Főiskola Médiainformatikai Intézet, Eger. 131. p. 


\section{MELLÉKLET}

1908-2019 között készült filmek, melyekben robot, illetve a mesterséges intelligencia (MI) fö-vagy mellékszereplöként megtalálható. Forrás: 1908-2014 közötti filmek esetében Dirks (2015), 2015-2019 köozö̈tti filmek esetében Net1 alapján összerendezték. a S zerzőók

A filmcimeket és a robotneveket az eredeti nyelven közöljük magyar forditás nélküil.

\begin{tabular}{|c|c|c|c|}
\hline Év & Ország & Cím & MI neve \\
\hline 1908 & USA & $\begin{array}{l}\text { The Fairylogue and Radio- } \\
\text { Plays }\end{array}$ & Tik-Tok (The Machine Man) \\
\hline 1919 & USA & The master Mystery & Q \\
\hline 1920 & Német & The Golem & Golem \\
\hline 1921 & Olasz & The Mechanical Man & Mechanical Man \\
\hline 1927 & Német & Metropolis & „Fake” Maria \\
\hline 1934 & Német & Der Herr Der Welt & $\begin{array}{l}\text { Giant Industrial Robot, Army of } \\
\text { Killer Robots }\end{array}$ \\
\hline 1936 & USA & Flash Gordon & Ming's Army/Guards \\
\hline 1936 & USA & Undersea Kingdom & Volkites \\
\hline 1939 & USA & The Phantom Creeps & Iron man \\
\hline 1939 & USA & The Wizard of Oz & $\begin{array}{l}\text { The Tin Man (aka The Tin } \\
\text { Woodman) }\end{array}$ \\
\hline 1940 & USA & Mysterious Doctor Satan & „Killer” Robot \\
\hline 1941 & USA & "The Mechanical Monsters" & „Mechanical Monsters” \\
\hline 1941 & USA & Man Made Monster & „Dynamo” Dan McCormick \\
\hline 1949 & $\mathrm{UK}$ & The Perfect Woman & Olga \\
\hline 1951 & USA & The Day The Earth Stood Still & $\begin{array}{l}\text { GORT (Genetically-Organized } \\
\text { Robotic Technology) }\end{array}$ \\
\hline 1952 & $\mathrm{UK}$ & $\begin{array}{l}\text { Mother Riley Meets the } \\
\text { Vampire }\end{array}$ & Mark 1 \\
\hline 1953 & USA & Robot Monster & Ro-Man \\
\hline 1954 & UK & Devil Girl From Mars & Chani \\
\hline 1954 & USA & Gog & Gog and Magog, Twin Robots \\
\hline 1954 & USA & Target Earth & Venutian Robot \\
\hline
\end{tabular}




\begin{tabular}{|c|c|c|c|}
\hline Év & Ország & Cím & MI neve \\
\hline 1954 & USA & Tobor the Great & Tobor \\
\hline 1956 & USA & Forbidden Planet & Robby the Robot \\
\hline 1957 & Japán & The Mysterians & Moguera \\
\hline 1957 & USA & Kronos & Kronos \\
\hline 1958 & Mexikó & $\begin{array}{l}\text { The Aztec Mummy Against } \\
\text { the Humanoid Robot }\end{array}$ & The Human-Robot \\
\hline 1958 & USA & The Colossus of New York & Colossus \\
\hline 1961 & Japán & Invasion of The Neptune Men & Neptune Men \\
\hline 1962 & SZU & Planet Bur & Jhon \\
\hline 1962 & UK & Dr. No & Dr. Julius No \\
\hline 1962 & USA & $\begin{array}{l}\text { The Creation of the } \\
\text { Humanoids }\end{array}$ & The Humanoids („Clickers”) \\
\hline 1963 & Japán & Tetsujin 28-gou & Giganator \\
\hline 1963 & USA & Jason and the Argonauts & Talos \\
\hline 1963 & USA & $\begin{array}{l}\text { Santa Claus Conquers the } \\
\text { Martians }\end{array}$ & Torg \\
\hline 1964 & UK & The Earth Dies Screaming & Alien Robots vagy Robo Aliens \\
\hline 1965 & Francia, Olasz & Alphaville & Alpha-60 \\
\hline 1965 & $\mathrm{UK}$ & Dr. Who \& the Daleks & The Daleks \\
\hline 1965 & USA & $\begin{array}{l}\text { Dr. Goldfoot and the Bikini } \\
\text { Machine }\end{array}$ & $\begin{array}{l}\text { Sexbots vagy Fembots, beleértve: } \\
\text { Robot \#11 (Diane) }\end{array}$ \\
\hline 1966 & USA & Cyborg 2087 & Cyborg Garth A7 \\
\hline 1966 & USA & Dr. Santa's Robot & Steel „Killer” Robot \\
\hline 1967 & Japán & King Kong Escapes & $\begin{array}{l}\text { Mecha Kong (vagy Mechani- } \\
\text { Kong) }\end{array}$ \\
\hline 1967 & UK & The Terronauts & Alien Robot \\
\hline 1968 & Francia, Olasz. & Barbarella & Robot devil dolls \\
\hline 1968 & Olasz, Spanyol & $\begin{array}{l}\text { Superargo and the Faceless } \\
\text { Giants }\end{array}$ & Faceless Giants \\
\hline 1968 & UK & 2001: A Space Odyssey & HAL 9000 Computer \\
\hline 1970 & USA & Colossus: The Forbin Project & $\begin{array}{l}\text { Colossus és Guardian szuper- } \\
\text { computerek }\end{array}$ \\
\hline 1971 & USA & THX 1138 & Enforcement cops \\
\hline 1972 & USA & Silent Running & $\begin{array}{l}\text { Dewey (Drone \# 1), Huey } \\
\text { (Drone \#2), és Louie (Drone \#3) }\end{array}$ \\
\hline
\end{tabular}




\begin{tabular}{|c|c|c|c|}
\hline Év & Ország & Cím & MI neve \\
\hline 1973 & Francia, Cseh & Fantastic Planet & Draags \\
\hline 1973 & Japán. & Gojira Tai Megaro & Jet Jaguar \\
\hline 1973 & UK, Ny.Német & Who? & $\begin{array}{l}\text { Roboman (Robotic Cyborg, } \\
\text { Android) }\end{array}$ \\
\hline 1973 & USA & Sleeper & $\begin{array}{l}\text { Robotic Household Butler (Rags } \\
\text { the Dog) }\end{array}$ \\
\hline 1973 & USA & Westworld & $\begin{array}{l}\text { Gunslinging Cowboy Robot } \\
\text { Model } 406\end{array}$ \\
\hline 1974 & Japán & Godzilla vs. MechaGodzilla & MechaGodzilla \\
\hline 1974 & USA & Dark Star & Bomb \#20 \\
\hline 1975 & USA & The Stepford Wives & $\begin{array}{l}\text { Bobbie Markowe, Joanna } \\
\text { Eberhart, és az összes „Stepford } \\
\text { Wives” (Stepfordi feleség) }\end{array}$ \\
\hline 1976 & USA & Logan's Run & Box \\
\hline 1977 & Kanada & Starship Invasions & Durbal \\
\hline 1977 & Olasz. & War of the Planets & Monstrous Robot Computer \\
\hline 1977 & USA & Demon Seed & $\begin{array}{l}\text { Proteus IV, és több } \\
\text { számítógépvezérelt robot }\end{array}$ \\
\hline 1977 & USA & Wizards & Necron-99 („Peace”) \\
\hline 1978 & Japán & Message From Space & Beba-2 \\
\hline 1978 & USA, Olasz & Starcrash & $\begin{array}{l}\text { Elle (Robotrendôr), Queen } \\
\text { Corelia’s Giant Female Robot, és } \\
\text { Two Sword-Wielding Robot } \\
\text { Golems of Count Arn }\end{array}$ \\
\hline 1979 & Kanada & $\begin{array}{l}\text { (H.G. Wells) The Shape of } \\
\text { Things to Come }\end{array}$ & $\begin{array}{l}\text { „Sparks” és Omus’ small army of } \\
\text { Robotic Minions }\end{array}$ \\
\hline 1979 & Olasz & Star Odyssey & $\begin{array}{l}\text { Army of Robotic Cyborg- } \\
\text { Androids, Hercules IV, Tiki és } \\
\text { Tilly }\end{array}$ \\
\hline 1979 & USA & Alien & Mother, Ash \\
\hline 1979 & USA & C.H.O.M.P.S. & C.H.O.M.P.S. \\
\hline 1979 & USA & Star Trek: The Motion Picture & V'Ger, android probe Ilia \\
\hline 1979 & USA & The Black Hole & $\begin{array}{l}\text { V.I.N.cent, the USS Cygnus crew, } \\
\text { (beleértve: B.O.B., Maximillian, és } \\
\text { más drónokat) }\end{array}$ \\
\hline 1979 & USA & Unidentified Flying Oddball & Doppelganger Hermes \\
\hline
\end{tabular}




\begin{tabular}{|c|c|c|c|}
\hline$\overline{\mathbf{E}} \mathbf{v}$ & Ország & Cím & MI neve \\
\hline 1980 & USA & Galaxina & Galaxina \\
\hline 1980 & USA & Saturn & Hector, Demigod 3 series \\
\hline 1981 & US, Kanada & Heavy Metal & sex robot \\
\hline 1981 & USA & Clash of the titans & Bubo \\
\hline 1981 & USA & Heartbeeps & $\begin{array}{l}\text { Val-Com } 17485 \text { and Aqua-Com } \\
\text { 89045, Catskill, Phil }\end{array}$ \\
\hline 1982 & USA & Android & Max 404, Cassandra \\
\hline 1982 & USA & Blade Runner & $\begin{array}{l}\text { Replicants: Leon, Zhora, Pris, } \\
\text { and Roy; also Rachael and Rick } \\
\text { Deckard }\end{array}$ \\
\hline 1982 & USA & Tron & Recognizers (rendőrrobotok) \\
\hline 1983 & USA & Superman III & Vera Webster \\
\hline 1984 & USA & Electric Dreams & Edgar \\
\hline 1984 & USA & Runaway & $\begin{array}{l}\text { Vectrocon Robot Spiders, and } \\
\text { Other Destructive High-Tech } \\
\text { Robotic Devices }\end{array}$ \\
\hline 1984 & USA & The Last Starfighter & Beta \\
\hline 1984 & USA & The Terminator & $\begin{array}{l}\text { Cyberdyne Systems Terminator } \\
\text { Model T-800 Series (sometimes } \\
\text { called Model 101) }\end{array}$ \\
\hline 1985 & USA & D.A.R.Y.L. & $\begin{array}{l}\text { D.A.R.Y.L. (Data Analysing Ro- } \\
\text { bot Youth Lifeform) }\end{array}$ \\
\hline 1985 & USA & Return to $\mathrm{Oz}$ & Tik-Tok \\
\hline 1985 & USA & Rocky IV & Sico theRobot \\
\hline 1985 & USA & Weird Science & Lisa \\
\hline 1986 & USA & Aliens & Lance Bishop 341-B \\
\hline 1986 & USA & Chopping Mall & Killbots \\
\hline 1986 & USA & Deadly Friend & Bee Bee \\
\hline 1986 & USA & Eliminators & Mandroid, and pet robot Spot \\
\hline 1986 & USA & Flight of the Navigator & $\begin{array}{l}\text { Max, R.A.L.F. (Robotic Assistant } \\
\text { Labor Facilitator) }\end{array}$ \\
\hline 1986 & USA & $\begin{array}{l}\text { Pee-wee's Playhouse (TV seri- } \\
\text { es) }\end{array}$ & Conky 2000 \\
\hline
\end{tabular}




\begin{tabular}{|c|c|c|c|}
\hline Év & Ország & Cím & MI neve \\
\hline 1986 & USA & Short Circuit & $\begin{array}{l}\text { Nova S-A-I-N-T (Strategic- } \\
\text { Artificially-Intelligent-Nuclear- } \\
\text { Transport), Number 5, renamed } \\
\text { Johnny-5 }\end{array}$ \\
\hline 1986 & USA & SpaceCamp & Jinx \\
\hline 1986 & USA & Transformers: The Movie & $\begin{array}{l}\text { Autobotok, Decepticonok, } \\
\text { Optimus Prime, Unicron, stb. }\end{array}$ \\
\hline 1987 & USA & *batteries not included & „Fix-it” Robotok \\
\hline 1987 & USA & Cherry 2000 & Cherry 2000 \\
\hline 1987 & USA & Making Mr. Right & Ulysses \\
\hline 1987 & USA & RoboCop & RoboCop, ED 209 \\
\hline 1987 & USA & Spaceballs & Dot Matrix \\
\hline 1989 & USA & Back to the Future Part II & Griff Tannen \\
\hline 1989 & USA & Cyborg & Cyborg Pearl Prophet \\
\hline 1990 & UK, USA & Hardware & $\begin{array}{l}\text { M.A.R.K. } 13 \text { prototype killer } \\
\text { combat droid }\end{array}$ \\
\hline 1990 & USA & Darkman & Darkman \\
\hline 1990 & USA & Edward Scissorhands & Edward Scissorhands \\
\hline 1990 & USA & Robot Jox & $\begin{array}{l}\text { Giant Mega Robots (például: } \\
\text { Western Market's red/white } \\
\text { Matsumoto-14, the } \\
\text { Confederation's Vovalefski-42) }\end{array}$ \\
\hline 1990 & USA & Spaced Invaders & Enforcer Drones, Shortstuff \\
\hline 1990 & USA & Total Recall & Johnny Cab \\
\hline 1991 & USA & $\begin{array}{l}\text { And You Thought Your } \\
\text { Parents Were Weird }\end{array}$ & Newman \\
\hline 1991 & USA & Bill \& Ted's Bogus Journey & $\begin{array}{l}\text { „Evil” Bill, Ted Robot } \\
\text { Doppelgangers }\end{array}$ \\
\hline 1991 & USA & Eve of Destruction & EVE VIII \\
\hline 1991 & USA & Guyver & The Guyver \\
\hline 1991 & USA & Terminator 2: Judgement Day & $\begin{array}{l}\text { Terminator Model T-800 } \\
\text { Terminator Series T-1000 }\end{array}$ \\
\hline 1992 & USA & Alien 3 & Bishop, and Bishop II \\
\hline 1992 & USA & Toys & Alsatia Zevo \\
\hline 1992 & USA & Universal Soldiers & $\begin{array}{l}\text { UniSols (Universal Soldiers): } \\
\text { Deveraux (GR44), Scott (GR13) }\end{array}$ \\
\hline
\end{tabular}




\begin{tabular}{|c|c|c|c|}
\hline Év & Ország & Cím & MI neve \\
\hline 1993 & UK & The Wrong Trousers & Techno-Trousers \\
\hline 1993 & USA & Cyborg Cop & Cyborg Assassin, Quincy \\
\hline 1993 & USA & RoboCop 3 & Otomo, Ninja assassin-androids \\
\hline 1993 & USA & Robot Wars & $\begin{array}{l}\text { Mega-Robot } 1 \text { és } 2 \text { (Mega-1 és } \\
\text { MRSA-2) }\end{array}$ \\
\hline 1994 & USA & APEX & $\begin{array}{l}\text { A.P.E.X. („Advanced Prototype } \\
\text { EXploration Units”), APEX } \\
\text { Sterilization Units }\end{array}$ \\
\hline 1994 & USA & Blankman & $\mathrm{J}-5$ \\
\hline 1995 & UK & A Close Shave & „Cyber-dog” Preston \\
\hline 1995 & USA & Evolver & Evolver \\
\hline 1995 & USA & Judge Dredd & ABC Warrior \\
\hline 1995 & USA & Screamers & $\begin{array}{l}\text { Mechanical „Screamers” vagy } \\
\text { Autonomous Mobile Swords } \\
\text { (David, Becker, and Jessica) }\end{array}$ \\
\hline 1995 & USA & Virtuosity & SID 6.7 \\
\hline 1996 & USA & $\begin{array}{l}\text { Mystery Science Theater 3000: } \\
\text { The Movie }\end{array}$ & $\begin{array}{l}\text { Crow T. Robot, Tom Servo, } \\
\text { Gypsy }\end{array}$ \\
\hline 1996 & USA & Robo Warriors & $\begin{array}{l}\text { Earthbot (Robo Warrior) vs. Tsu } \\
\text { Garu }\end{array}$ \\
\hline 1996 & $\overline{\mathrm{USA}}$ & Solo & Solo, Solo II \\
\hline 1996 & USA & Star Trek: First Contact & The Borg, the Borg Queen \\
\hline 1997 & USA & Alien: Resurrection & Call \\
\hline 1997 & USA & $\begin{array}{l}\text { Austin Powers: International } \\
\text { Man of Mystery }\end{array}$ & Fembots \\
\hline 1997 & USA & Flubber & Weebo, Weber, Weebette \\
\hline 1998 & USA & Lost in Space & $\begin{array}{l}\text { Environmental Control Robot } \\
\text { Model B-9, Unnamed Cyclops } \\
\text { Robot, Biomechanical (CGI) Ro- } \\
\text { bot Spiders }\end{array}$ \\
\hline 1998 & USA & Small Soldiers & $\begin{array}{l}\text { Akció Figurák: the Commando } \\
\text { Elite, the Gorgonites }\end{array}$ \\
\hline 1998 & USA & The Outsider & $\begin{array}{l}\text { Astor, the Outsider - androidok } \\
\text { (RCUs, Robotic Carbon Units) }\end{array}$ \\
\hline 1999 & USA & $\begin{array}{l}\text { Austin Powers: The Spy Who } \\
\text { Shagged Me }\end{array}$ & FemBots \\
\hline
\end{tabular}




\begin{tabular}{|c|c|c|c|}
\hline Év & Ország & Cím & MI neve \\
\hline 1999 & USA & Bicentennial Man & $\begin{array}{l}\text { Robo-servant (Model \# NDR- } \\
\text { 114) Andrew Martin }\end{array}$ \\
\hline 1999 & USA & Futurama (TV series) & $\begin{array}{l}\text { Robot Bender, más néven } \\
\text { Bender Bending Rodríguez } \\
\text { (Bending Unit 22) }\end{array}$ \\
\hline 1999 & USA & Inspector Gadget & RoboGadget \\
\hline 1999 & USA & $\begin{array}{l}\text { Star Wars: Episode } 1 \text { - The } \\
\text { phantom Menace }\end{array}$ & The Battle Droids \\
\hline 1999 & USA & The Iron Giant & Iron Giant \\
\hline 1999 & USA & The matrix & The sentinels \\
\hline 2000 & USA & Red Planet & $\begin{array}{l}\text { AMEE (Autonomous Mapping } \\
\text { Exploration and Evasion), a Ro- } \\
\text { bot Scout }\end{array}$ \\
\hline 2001 & Japán & Metropolis & Tima \\
\hline 2001 & USA & A.I.: Artificial Intelligence & $\begin{array}{l}\text { David, Gigolo Joe, Gigolo Jane, } \\
\text { Teddy }\end{array}$ \\
\hline 2001 & USA & Jason $\mathrm{X}$ & KAY-Em 14 \\
\hline 2002 & USA & Minority Report & Spyder Robots \\
\hline 2002 & USA & S1m0ne & S1m0ne \\
\hline 2002 & USA & Star Trek Nemesis & B-4 \\
\hline 2002 & USA & $\begin{array}{l}\text { The Adventures of Pluto } \\
\text { Nash }\end{array}$ & Bruno, Model 63 Deluxe \\
\hline 2002 & USA & The Santa Clause 2 & Toy Santa, Army of Toy Soldiers \\
\hline 2002 & USA & Treasure Planet & $\begin{array}{l}\text { B.E.N. (Bio-Electronic Naviga- } \\
\text { tor) }\end{array}$ \\
\hline 2003 & USA & Inspector Gadget 2 & G2 \\
\hline 2003 & USA & $\begin{array}{l}\text { Terminator 3: Rise of the } \\
\text { Machines }\end{array}$ & $\begin{array}{l}\text { Terminator Series X, The } \\
\text { Terminator T- } 850\end{array}$ \\
\hline 2004 & USA & I, Robot & $\begin{array}{l}\text { Sonny (NS-5, Nestor Class-5) } \\
\text { Robot, és más NS- } 5 \text { robotok }\end{array}$ \\
\hline 2004 & USA & Rottweiler & Rottweiler Police Dog \\
\hline 2004 & USA & $\begin{array}{l}\text { Sky Captain and the World of } \\
\text { Tomorrow }\end{array}$ & Giant robots \\
\hline 2004 & USA & The Incredibles & Omnidroid \\
\hline 2004 & USA & The Stepford Wives & Stepfordi feleségek \\
\hline
\end{tabular}




\begin{tabular}{|c|c|c|c|}
\hline Év & Ország & Cím & MI neve \\
\hline 2005 & USA & Robots & $\begin{array}{l}\text { Rodney Copperbottom, s az ösz- } \\
\text { szes többi robot }\end{array}$ \\
\hline 2005 & USA & Stealth & EDI (Extreme Deep Invader) \\
\hline 2005 & USA & $\begin{array}{l}\text { The Hitchhiker's Guide to the } \\
\text { Galaxy }\end{array}$ & $\begin{array}{l}\text { Marvin (GPP, Genuine People } \\
\text { Personalities) prototípus android }\end{array}$ \\
\hline 2006 & USA & (Daft Punk's) Electroma & Daft Punk robotok \\
\hline 2006 & USA & Automathons & Robotseregek \\
\hline 2006 & USA & X-Men: The Last Stand & Sentinel \\
\hline 2007 & USA & Meet the Robinsons & DOR-15 (Doris) and Carl \\
\hline 2007 & USA & Transformers & $\begin{array}{l}\text { Optimus Prime, Autobots, } \\
\text { Decepticons és más robotok }\end{array}$ \\
\hline 2007 & USA & Transmorphers & Z-bots \\
\hline 2008 & USA & Hellboy II: The Golden Army & The Golden Army \\
\hline 2008 & USA & Meet Dave & Dave Ming Chang \\
\hline 2008 & USA & WALL-E & $\begin{array}{l}\text { WALL·E, EVE, és az AXIOM } \\
\text { űrhajó más robotjai, például: M- } \\
\text { O („Moe”, Microbe Obliterator), } \\
\text { AUTO (pilótarobot), GO-4 } \\
\text { (AUTO asszisztense), BUF-4 } \\
\text { (Buffer cleaning robot), BRL-A } \\
\text { (esernyő-robot), D-FIB } \\
\text { (defibrillator-robot), PR-T } \\
\text { („Pret-ty”, kozmetikus robot), } \\
\text { HAN-S (Masszázs robot), NAN- } \\
\text { E (Nanny dada-robot),THIRST- } \\
\text { E (italadagoló robot), VAQ-M } \\
\text { (Vákuum-robot), VEND-R } \\
\text { (élelmiszeradagoló robot), VN- } \\
\text { GO (festő robot, neve Vincent } \\
\text { Van Gogh-ra utal) }\end{array}$ \\
\hline 2009 & $\begin{array}{l}\text { Honkong, } \\
\text { USA, Japán }\end{array}$ & Astro Boy & Astro Boy és több más robot \\
\hline 2009 & UK & Moon & GERTY 3000 \\
\hline 2009 & USA & RoboDoc & MD 63 (RoboDoc) \\
\hline 2009 & USA & $\begin{array}{l}\text { Super Capers: The Origins of } \\
\text { Ed and the Missing Bullion }\end{array}$ & Robo \\
\hline
\end{tabular}




\begin{tabular}{|c|c|c|c|}
\hline Év & Ország & Cím & MI neve \\
\hline 2009 & USA & 9 & $\begin{array}{l}\text { Nine „Stitchpunk” Robots (há- } \\
\text { tukon számmal jelölt robotok, } \\
\text { B.R.A.I.N. (Binary Reactive } \\
\text { Artificially Intelligent } \\
\text { Neurocircuit) }\end{array}$ \\
\hline 2009 & USA & $\begin{array}{l}\text { Scooby-Doo! and the Samurai } \\
\text { Sword }\end{array}$ & $\begin{array}{l}\text { A Fekete Szamuráj robotnindzsái } \\
\text { (Robot Ninjas of the Black } \\
\text { Samurai) }\end{array}$ \\
\hline 2009 & USA & Terminator Salvation & $\begin{array}{l}\text { Aerostats, Harvesters, Moto- } \\
\text { Terminators, Hydrobots, Series } \\
\text { T-600 Terminators, a T-RIP } \\
\text { (Resistance Infiltrator } \\
\text { Prototype), és az új T-800-as } \\
\text { Terminátor }\end{array}$ \\
\hline 2010 & India & Robot & Chitti \\
\hline 2011 & Kanada & Android Re-Enanctment & $\begin{array}{l}\text { Candy Droober, Franklin } \\
\text { Droober, Maureen Droober és } \\
\text { Trace Mayter }\end{array}$ \\
\hline 2011 & Spanyol & Eva & $\begin{array}{l}\text { Android Prototype SI-9, Servant } \\
\text { Robot Max, Robotic Pet Cat } \\
\text { Gris, és Eva }\end{array}$ \\
\hline 2011 & USA & Real Steel & $\begin{array}{l}\text { Ambush, Noisy Boy, Atom, } \\
\text { Zeus }\end{array}$ \\
\hline 2011 & USA & The Muppets & 80's Robot \\
\hline 2012 & USA & Prometheus & David \\
\hline 2013 & USA & Her & Samantha \\
\hline 2013 & USA & Oblivion & Tet \\
\hline 2014 & USA & Big Hero 6 & Baymax, Microbots \\
\hline 2014 & USA & Interstellar & TARS, CASE \\
\hline 2014 & USA & The LEGO Movie & Sheriff Not-a-Robot, Robo Pilots \\
\hline 2015 & Japan & Psycho-pass: The Movie & Sibyl System \\
\hline 2015 & UK & Ex Machina & Ava \\
\hline 2015 & USA, Mexikó & Chappie & Chappie \\
\hline 2015 & USA & $\begin{array}{l}\text { Star Wars: The Force } \\
\text { Awakens }\end{array}$ & BB-8, C-3PO, R2-D2 \\
\hline 2015 & USA & $\begin{array}{l}\text { Terminator Genisys, vagy: } \\
\text { Terminator } 5\end{array}$ & $\begin{array}{l}\text { T-800, T-1000, T-3000, Skynet, } \\
\text { Genisys }\end{array}$ \\
\hline
\end{tabular}




\begin{tabular}{|c|c|c|c|}
\hline Év & Ország & Cím & MI neve \\
\hline 2015 & USA & Avengers: Age of Ultron & $\begin{array}{l}\text { Iron Legion, Veronica, } \\
\text { Hulkbuster, Ultron, JARVIS, } \\
\text { F.R.I.D.A.Y, Vision }\end{array}$ \\
\hline 2015 & USA & Uncanny & Kressen \\
\hline 2016 & UK & Kill Command & S.A.R. \\
\hline 2016 & USA & Max Steel & Steel \\
\hline 2016 & USA & Morgan & Morgan, Lee Weathers \\
\hline 2016 & USA & Passengers & Ship androids \\
\hline 2016 & USA & Rogue One: A Star Wars Story & $\mathrm{K}-2 \mathrm{SO}$ \\
\hline 2017 & USA & Alien: Covenant & David \\
\hline 2017 & USA & Blade Runner 2049 & Replicants \\
\hline 2017 & USA & Ghost in the Shell & Motoko Kusanagi \\
\hline 2017 & USA & Power Rangers & Alpha 5, Zordon, Zords \\
\hline 2017 & USA & Spider-Man: Homecoming & Karen, F.R.I.D.A.Y \\
\hline 2017 & USA & Star Wars: The Last Jedi & BB-8, C-3PO, R2-D2 \\
\hline 2018 & Ausztrália & Upgrade & Stem \\
\hline 2018 & India & 2.0 & Chitti és Chitti 2.0 \\
\hline 2018 & Szerbia & A.I. Rising & Nimani \\
\hline 2018 & UK & 2036 Origin Unknown & ARTI \\
\hline 2018 & USA & Avengers: Infinity War & F.R.I.D.A.Y, Vision \\
\hline 2018 & USA & A-X-L & A-X-L \\
\hline 2018 & USA & Extinction & Synths \\
\hline 2018 & USA & Maniac & GRTA \\
\hline 2018 & USA & Replicas & 345-ös alany \\
\hline 2018 & USA & Tau & Tau \\
\hline 2018 & USA & Zoe & Ash \\
\hline 2019 & USA & Alita: Battle Angel & Alita és más robotok \\
\hline 2019 & USA & Serenity & A Plymouth-sziget lakói \\
\hline 2019 & USA & Superintelligence & Szuperintelligencia \\
\hline 2019 & USA & Terminator: Dark Fate & T-800, Skynet, Rev-9, Grace \\
\hline 2019 & USA/Ausztrália & I Am Mother & Mother \\
\hline
\end{tabular}




\section{Sorozatok:}

\begin{tabular}{|l|l|l|l|}
\hline $\mathbf{E ́ v}$ & Ország & Cím & MI neve \\
\hline $1963-1964$ & USA & Eight Man (TV series) & 8 Man, or 8th Man \\
\hline $1963-1966$ & USA & Astro Boy & $\begin{array}{l}\text { Astro Boy (más néven: Mighty } \\
\text { Atom, Astro, Toby, Robot Boy, } \\
\text { Boy Robot) }\end{array}$ \\
\hline $1977-2005$ & USA & $\begin{array}{l}\text { Star Wars (1977), The Empire } \\
\text { Strikes Back (1980), Return of } \\
\text { the Jedi (1983), Star Wars: } \\
\text { Episode I - The Phantom } \\
\text { Menace (1999), Star Wars: } \\
\text { Episode II - Attack of the } \\
\text { Clones (2002), Star Wars: } \\
\text { Episode III -- Revenge of the } \\
\text { Sith (2005) }\end{array}$ & \\
& & $\begin{array}{l}\text { Not Quite Human films: Not } \\
\text { Quite Human (1987), Not } \\
\text { Quite Human II (1989), Still } \\
\text { Not Quite Human (1992) }\end{array}$ & Chip \\
\hline $1987-1992$ & USA & Death Machine & „Warbeast” Death Machine \\
\hline $1994 / 1995$ & UK & $\begin{array}{l}\text { Star Trek films: Star Trek: } \\
\text { Generations (1994), Star Trek: } \\
\text { First Contact (1996), Star Trek: } \\
\text { Insurrection (1998), Star Trek: } \\
\text { Nemesis (2002) }\end{array}$ & Data \\
\hline $1994-2002$ & USA & & \\
& & &
\end{tabular}




\section{MÜHELY, RENDEZVÉNY}




\title{
A K+F STÚDIÓ ÉS A MESTERSÉGES INTELLIGENCIA (MÜHELYBEMUTATÓ)
}

\author{
Mező Katalin (PhD) \\ Szerzô e-mail címe: \\ kata.mezo1@gmail.com
}

Mező Katalin (2019): A K+F Stúdió és a mesterséges intelligencia (műhelybemutató). Mesterséges intelligencia - interdiszciplináris folyóirat, I. évf. 2019/1. szám. 97-100. doi: 10.35406/MI.2019.1.97

A K+F Stúdió Kft. (www.kpluszf.com) 2011-ben jött létre Magyarországon, Debrecenben. Tevékenységét tekintve a kutatás, fejlesztés és innováció terén tréningeket, tanácsadást biztosít és kezdő vállalkozóknak, kutatóknak nyújt tanácsadói szolgáltatást, menedzsment jellegű támogatást.

\section{K+F STÚDIó Kft.}

A Stúdió saját kutatási projektjei jelenleg:

- OxIPO-projekt. Cél: a humán információfeldolgozás hatékonyságának növelése.

- REenergy-projekt. Cél: megújuló energiaforrások privát, háztartási és ipari megoldási lehetőségeinek feltárása, kidolgozása.

- PSYWAR-Technology projekt. Cél: a lélektani hadviselés módszer- és eszközrend- szerének katonai, üzleti, sport és pedagógiai vonatkozásainak feltárása.

- AI-projek.t. Cél: a mesterséges intelligencia (MI, artificial intelligence, AI) cél-, eszköz- és hatásorientált kutatása, illetve MI fejlesztés, s teljesítményre ösztönző, dústó jellegű tehetséggonodzás az MI terén.

A K+F Stúdió Kft. társadalmi felelősségvállalási (CSR) stratégiája részeként Open Access (nyiltt hozzáférésű, Olvasóknak és Szerzőknek egyaránt dijmentes interdiszciplináris internetes folyóiratokat indított 2019ben - ezek:

- OxIPO

- Lélektan és hadviselés

- Mesterséges intelligencia

E lapokhoz gyors elérést biztosít a http://www.kpluszf.com/KFS_folyoiratok.h tml elosztó oldal. 


\section{Tehetséggondozás és CSR}

Ugyancsak a társadalmi felelősségvállalási (CSR) stratégia keretében fordít a Stúdió kiemelt figyelmet a tehetséggondozásra, s mûködik együtt a Kocka Kör Tehetséggondozó Kulturális Egyesülettel (a Kocka Kör honlapja: www.kockakor.hu), illetve a Professzorok az Európai Magyarországért Egyesülettel (weblapja: www.peme.hu). E szervezetek más part-nerszervezeteket is bevonva - közös rendezésben megvalósuló nemzetközi konferenciákat, hazai és külföldi tréningeket, akkreditált pedagógus továbbképzéseket és könyvkiadásokat valósítanak meg - sok esetben nonprofit formában, tehetségsegítő módon.

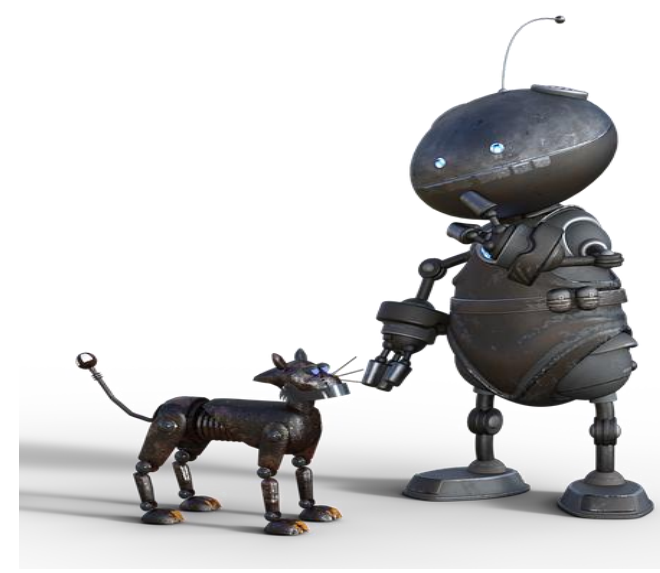

A K+F Stúdió Kft. tehetséggondozó tevékenysége az alábbi tartalmi elemekkel jellemezhető:

a) oktatás: tréning jellegű (kreativitásfejlesztéssel, kreatív tanulásfejlesztéssel, személyi- ségfejlesztéssel foglalkozó) tehetséggondozó programokba évente 100 fiatal (11-25 évesek) kapcsolódik be. Interdiszciplináris hallgatói kutatócsoportot működtetünk 2015 óta (létszám: kb. 20 fö/év), mely csoportokban innovációra (is) tanítjuk a résztvevőket. A társaság múködésének 6 éve alatt tehetség témakörben 6 akkreditált pedagógus továbbképzést hozott létre, melyen több száz pedagógus vett részt eddig.

b) előadás: tehetséges fiataloknak, pedagógusoknak, pszichológusoknak szóló 0,5-5 órás előadások (kb. 8000 fős hallgatóság/év)

c) könyvkiadás: 5 könyv jelent meg eddig a $\mathrm{K}+\mathrm{F}$ Stúdió Kft. gondozásában.

d) tanulmányok megjelentetése: 30-50 tanulmány/év mennyiségben.

e) együttműködések: 3 köznevelési intézménnyel és 5 civil szervezettel van partneri szerződésünk tehetséggondozás terén. Nem partneri szerződés formájában további 20 szervezettel van együttműködésünk évente. Közvetett hatásunk rajtuk keresztül kb. 2000 fö/év.

f) tanulmányi verseny: nemzetközi tehetséggondozó tanulmányi versenyek előkészítése történik (tanulásmódszertan, mesterséges intelligencia, idegen nyelvek terén). Terv: 1000 fö/verseny.

g) konferenciaszervezés: társszervezőként és főszervezőként is történik konferenciaszervezés.

h) Határon túli kapcsolatok: felsőoktatási intézményekkel, civil szervezetekkel, önkormányzattal.

i) tanácsadás: tehetség, $\mathrm{K}+\mathrm{F}+\mathrm{I}$, vállalkozásfejlesztés témakörökben. 


\section{A K+F Stúdió és az MI kutatás}

A mesterséges intelligencia témakörhöz kapcsolódó AI-projekt három féle megközelítéssel fordul a témához. Egyrészt az „MI = cél” jellegú kutatás keretében mesterséges intelligencia létrehozásával kapcsolatos kutatás, fejlesztés történik. „Digitális organizmus”-ok fejlesztése révén a humán tanulás (ami nem azonos a „gépi tanulás"-nak nevezett MI témakörrel!) modellezésére törekszünk, illetve a kreatív teljesítményeket segítő, illetve azokat önállóan előállító MI fejlesztésére fókuszálunk.

Másrészt az „MI = eszköz” orientációjú kutatásaink alapján szakértôi rendszerek fejlesztése is céljaink között szerepel különböző témakörökben, szakterületeken - például statisztika, pszichodiagnosztika, tanácsadás, „Okos otthon”, oktatás, irodai alkalmazások, intelligens műszervek, stb..

Végül az MI hatásorientált kutatása során arra keressük a választ, hogy miként hat a mesterséges intelligencia a világra, s viszont különös tekintettel az „ember-gép”, „társadalom-gép” relációkban. Az „MI-Világ” kölcsönhatás téma a filozófiától kezdve a jog-, a hit-, a média-, a had-, a gazdaság- és az orvostudományon, a pszichológián és a pedagógián át a matematikáig és az informatikáig nyújt izgalmas kutatási lehetôségeket.

\section{MI tehetséggonodzó mühely}

A $\mathrm{K}+\mathrm{F}$ Stúdió a mesterséges intelligenciával kapcsolatos szemléletformálás, társadalmi érzékenyítés, s pályaszocializácó céljából 2019. szeptemberétől tehetséggondozó múhelyt indít.

\section{F E L H Í V Á S}

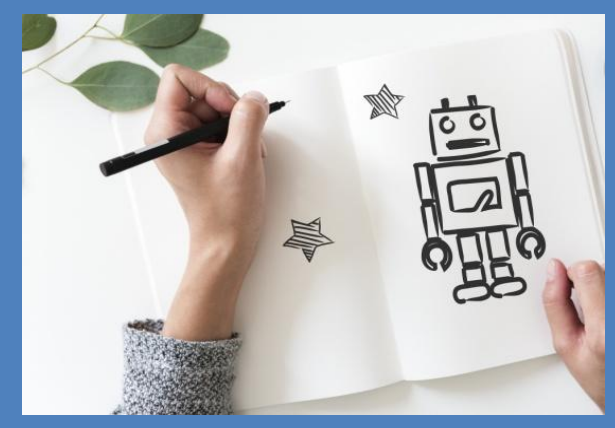

A K +F Stúdió Kft. „Mesterséges intelligencia” tehetséggondozó mühelye

együttmúködó partnereket keres,

$s$ eqúton várja

szervezetek, magánszemélyek

önkéntes csatlakorását

a következő (egymást nem kizáró) területeken:

- alprojektek kidolgozása, vezetése,

- szervezés, mentorálás, tananyagfejlesztés,

- finanszírozás (szponzoráció),

- szoftver/hardver biztosítás,

- programozás, grafika, animáció,

- egyéb.

\section{Kapcsolatfelvétel:}

a +36-30-6561565 mobilszámon vagy az info@kpluszf.com e-mail címen lehetséges.

Kontaktszemély:

Mező Ferenc (PhD)

programigazgató

\section{Határidö:}

2019. december 31 . 


\section{Mesterséges intelligencia folyóirat}

Az MI népszerūsítése érdekében folyóiratot is múködtet a Stúdió. A Mesterséges intelligencia interdiszciplináris tudományos folyóirat a $\mathrm{K}+\mathrm{F}$ Stúdió Kft. által, társadalmi felelősségvállalási (CSR) stratégia keretében alapított és kiadott, félévente megjelenő Open Access (nyilt hozzáférésű) tudományos internetes periodika, amely a címében megadott témakörrel kapcsolatban ad közre elméleti és gyakorlati ismereteket közlő tanulmányokat.

A lap az alábbi honlapon keresztül érhető el (itt megtalálható a lap impresszuma is): http://www.kpluszf.com/KFS_folyoiratok.html

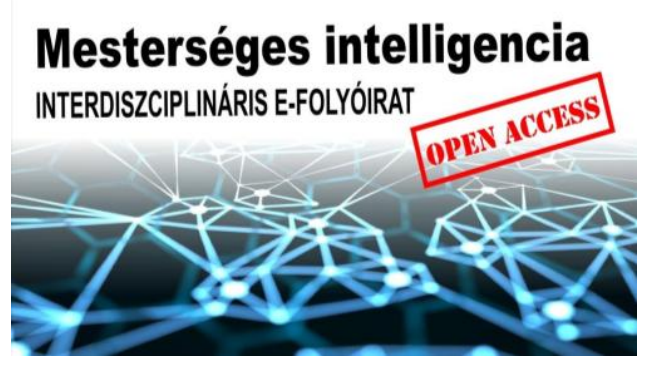

A folyóirat célja: a mesterséges intelligencia kutatásával, gyakorlati alkalmazásával kapcsolatos tudományos eredmények, projekt-, termékismertetések, cég- és szervezet bemutatók közlése révén publikációs felületet nyújtani az interdiszciplináris orientációjú kutatók, kutatócsoportok, gyakorlati szakemberek számára, annak érdekében, hogy elősegítse a hagyományos diszciplináris kereteken átívelő tudományos eredmények, innovációk létrejöttét, illetve népszerűsítését. A mesterséges intelligencia fejlesztése, gyakorlati alkalmazása, s az ezek alapján megvalósuló, illetve prognosztizálható társadalmi-gazdasági hatások a tudományágak széles köre számára nyújthatnak kutatási témát. A mesterséges intelligencia ugyanis célja, tárgya, illetve eszköze lehet a Magyar Tudományos Akadémia 2017-ben közreadott tudományági nómenklatúrája minden tudományterületének.

Tisðtelettel várjuk az Ön tanulmányát is! 